\title{
Red-emitting dibenzodiazepinone derivatives as fluorescent dualsteric probes for the muscarinic acetylcholine $\mathbf{M}$ receptor
}

Xueke She, Andrea Pegoli, Corinna G. Gruber, David Wifling, Jessica Carpenter, Harald Hübner, Mengya Chen, Jianfei Wan, Günther Bernhardt, Peter Gmeiner, Nicholas D. Holliday, and Max Keller J. Med. Chem., Just Accepted Manuscript • DOI: 10.1021/acs.jmedchem.9b02172 • Publication Date (Web): 01 Apr 2020

Downloaded from pubs.acs.org on April 13, 2020

\section{Just Accepted}

"Just Accepted" manuscripts have been peer-reviewed and accepted for publication. They are posted online prior to technical editing, formatting for publication and author proofing. The American Chemical Society provides "Just Accepted" as a service to the research community to expedite the dissemination of scientific material as soon as possible after acceptance. "Just Accepted" manuscripts appear in full in PDF format accompanied by an HTML abstract. "Just Accepted" manuscripts have been fully peer reviewed, but should not be considered the official version of record. They are citable by the Digital Object Identifier (DOI®). "Just Accepted" is an optional service offered to authors. Therefore, the "Just Accepted" Web site may not include all articles that will be published in the journal. After a manuscript is technically edited and formatted, it will be removed from the "Just Accepted" Web site and published as an ASAP article. Note that technical editing may introduce minor changes to the manuscript text and/or graphics which could affect content, and all legal disclaimers and ethical guidelines that apply to the journal pertain. ACS cannot be held responsible for errors or consequences arising from the use of information contained in these "Just Accepted" manuscripts. 


\section{Red-emitting dibenzodiazepinone derivatives as}

\section{fluorescent dualsteric probes for the muscarinic acetylcholine $\mathrm{M}_{2}$ receptor}

Xueke She, ${ }^{\dagger, \$, \#}$ Andrea Pegoli, ${ }^{\dagger, \ldots, \#}$ Corinna G. Gruber, ${ }^{\dagger}$ David Wifling, ${ }^{\dagger, *}$ Jessica Carpenter, ${ }^{\ddagger}$

Harald Hübner," Mengya Chen, ${ }^{\dagger,}{ }^{\perp}$ Jianfei Wan, ${ }^{\dagger,}$ Günther Bernhardt, ${ }^{\dagger}$ Peter Gmeiner,"

Nicholas D. Holliday ${ }^{*}+$ and Max Keller, ${ }^{*}$,

†Institute of Pharmacy, Faculty of Chemistry and Pharmacy, University of Regensburg,

Universitätsstr. 31, D-93053 Regensburg, Germany

$\ddagger$ School of Life Sciences, University of Nottingham, Queen’s Medical Centre, Derby Road,

Nottingham NG7 2UH, United Kingdom

"Department of Chemistry and Pharmacy, Medicinal Chemistry, Friedrich Alexander

University, Nikolaus-Fiebiger-Straße 10, D-91058 Erlangen, Germany 


\begin{abstract}
Fluorescently labeled dibenzodiazepinone-type muscarinic acetylcholine receptor (MR) antagonists, including dimeric ligands, were prepared using red-emitting cyanine dyes. Probes containing a fluorophore with negative charge showed high $\mathrm{M}_{2} \mathrm{R}$ affinities ( $\mathrm{p} K_{\mathrm{i}}$ (radioligand competition binding): 9.10-9.59). Binding studies at $M_{1}$ and $M_{3}-M_{5}$ receptors indicated a $M_{2} R$ preference. Flow cytometric and high-content imaging saturation and competition binding $\left(\mathrm{M}_{1} \mathrm{R}, \mathrm{M}_{2} \mathrm{R}\right.$ and $\left.\mathrm{M}_{4} \mathrm{R}\right)$ confirmed occupation of the orthosteric site. Confocal microscopy revealed that fluorescence was located mainly at the cell membrane $\left(\mathrm{CHO}-\mathrm{hM}_{2} \mathrm{R}\right.$ cells $)$. Results from dissociation and saturation binding experiments $\left(M_{2} R\right)$ in the presence of allosteric $M_{2} R$ modulators (dissociation: W84, LY2119620 and alcuronium; saturation binding: W84) were consistent with a competitive mode of action between the fluorescent probes and the allosteric ligands. Taken together, these lines of evidence indicate that these ligands are useful fluorescent molecular tools to label the $\mathrm{M}_{2} \mathrm{R}$ in imaging and binding studies, and suggest that they have a dualsteric mode of action.
\end{abstract}




\section{Introduction}

Fluorescence-based techniques have been increasingly used for studying ligand-receptor interactions, and hence there is a growing demand for suitable fluorescent receptor ligands. Compared with radiolabeled probes, fluorescent ligands are advantageous with respect to safety precautions and waste disposal. Moreover, they are applicable to fluorescence microscopy and flow cytometry, routine techniques in many laboratories, as well as to various homogeneous assay systems requiring specialized multimode plate readers, ${ }^{1-3}$ such as high-content imaging based assays, or polarization based fluorescence anisotropy receptor binding studies. ${ }^{4,5} \mathrm{~A}$ general issue regarding the design of small-molecule fluorescent ligands is the impairment of the bioactivity caused by conjugation to bulky fluorophores. For this reason, the pharmacophore (ligand) and the fluorophore are often held apart by a linker or spacer moiety. ${ }^{6-8}$ There are numerous reports on fluorescent probes for GPCRs, for instance for neuropeptide $\mathrm{Y},{ }^{9-14}$ histamine, ${ }^{15-19}$ opioid, ${ }^{20-22}$ dopamine, ${ }^{23,24}$ neurotensin, ${ }^{25-28}$ and adenosine ${ }^{29}$ receptors. Concerning muscarinic acetylcholine receptors (MRs), several fluorescently labeled $M_{1} R$ ligands, derived from the $\mathrm{M}_{1}$ subtype preferring MR antagonist pirenzepine, were reported (for instance, compound 1, Figure 1A) ${ }^{30,31}$ Likewise, conjugation of the MR ligands tolterodine, telenzepine and AC-42 to fluorescent dyes resulted in probes with high to moderate $M_{1} R$ affinity (compounds 2-4, Figure 1A). ${ }^{32-35}$ Compounds $\mathbf{1}$ and $\mathbf{4}$ were reported to bind bitopically/dualsterically to the $\mathrm{hM}_{1} \mathrm{R},{ }^{30,35}$ i.e. they bind simultaneously to the orthosteric and an allosteric site of the receptor. In contrast to the $\mathrm{M}_{1} \mathrm{R}$, reports on fluorescent probes for the $\mathrm{M}_{2}-\mathrm{M}_{5}$ receptor subtypes, characterized at cloned MRs, are rare: the non-selective fluorescent $M_{1} R$ ligands 2 and 3 were reported to exhibit also high $M_{2}-M_{5}$ receptor and high $M_{2} R$ affinity, respectively (Figure 1A), ${ }^{33,36}$ and pyridinium-styryl-type fluorescent dyes were shown to bind to all MR subtypes at medium nanomolar concentrations. ${ }^{37}$ 
A
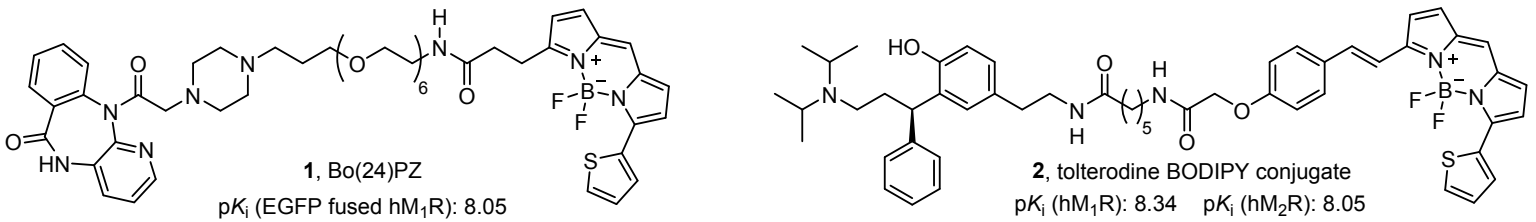
$\mathrm{p} K_{\mathrm{i}}\left(\mathrm{hM}_{1} \mathrm{R}\right): 8.34 \quad \mathrm{p} K_{\mathrm{i}}\left(\mathrm{hM}_{2} \mathrm{R}\right): 8.05$ $\mathrm{p} K_{\mathrm{i}}\left(\mathrm{hM}_{3} \mathrm{R}\right): 7.99 \quad \mathrm{p} K_{\mathrm{i}}\left(\mathrm{hM}_{4} \mathrm{R}\right): 8.20$ $\mathrm{p} K_{\mathrm{i}}\left(\mathrm{hM}_{5} \mathrm{R}\right): 7.76$
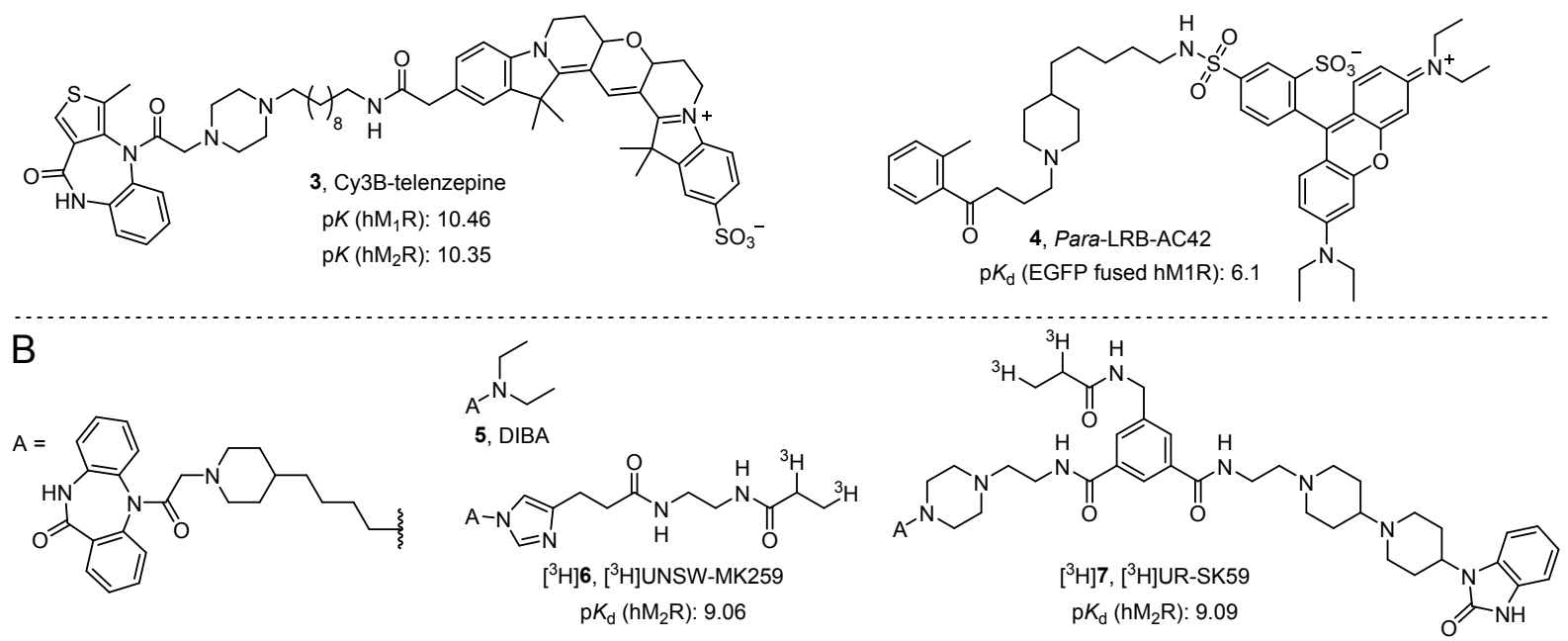

Figure 1. (A) Structures, $M_{1} R$ affinities (and $M_{2} R$ binding data, if available) of the reported

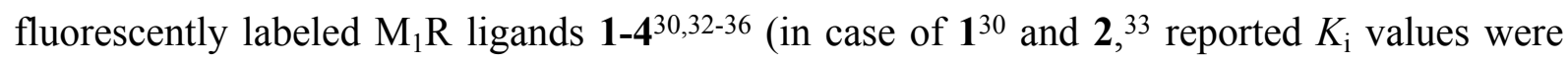
converted to $\mathrm{p} K_{\mathrm{i}}$ values). (B) Structures and $\mathrm{M}_{2} \mathrm{R}$ affinities of the dibenzodiazepinone-type $\mathrm{MR}$ ligand DIBA and the DIBA-derived radioligands $\left[{ }^{3} \mathrm{H}\right] \mathrm{UR}-\mathrm{MK} 259$ and $\left[{ }^{3} \mathrm{H}\right] \mathrm{UR}-\mathrm{SK} 59$ (reported $K_{\mathrm{d}}$ values were transformed to $\mathrm{p} K_{\mathrm{d}}$ values). ${ }^{38,39}$

Prompted by the recently reported synthesis and characterization of radiolabeled dualsteric $\mathrm{M}_{2} \mathrm{R}$ antagonists derived from the $\mathrm{M}_{2} \mathrm{R}$ preferring dibenzodiazepinone DIBA (5) ${ }^{40}$ (for instance, $\left[{ }^{3} \mathrm{H}\right] 6$ and $\left[{ }^{3} \mathrm{H}\right] 7$, Figure 1B), ${ }^{38,39}$ exhibiting high $\mathrm{M}_{2} \mathrm{R}$ affinity, we conjugated two types of redemitting fluorophores to previously reported amine-functionalized dibenzodiazepinone derivatives. ${ }^{38,39}$ This approach yielded twelve fluorescent MR ligands, which were studied with respect to their $M_{1} R-M_{5} R$ affinities. Selected fluorescent ligands were characterized by flow cytometry and high-content imaging based binding studies as well as by confocal microscopy to investigate their applicability as molecular tools. 


\section{Results and Discussion}

Chemistry. The fluorescent monomeric and dimeric dibenzodiazepinone-type MR ligands $\left(\mathbf{1 0},{ }^{41} \mathbf{1 2},{ }^{41} \mathbf{1 4},{ }^{41} \mathbf{1 6 - 1 8},{ }^{41} \mathbf{2 0},{ }^{41} \mathbf{2 2}, \mathbf{2 3}, \mathbf{2 7}, \mathbf{2 8}, \mathbf{3 0}\right)$ were prepared from previously reported amine-functionalized precursor compounds $\left(\mathbf{8},{ }^{42} \mathbf{1 5},{ }^{39} \mathbf{2 1},{ }^{42} \mathbf{2 6},{ }^{38} \mathbf{2 9}{ }^{39}\right)$ and the pyrylium dye $\mathbf{9}$ as well as the indolinium-type cyanine dye succinimidyl esters 11, 13 and $\mathbf{1 9}$ (Scheme 1). The latter contain the same fluorophore core structure but differ with respect to attached sulfonic acid groups leading to different net charges of the dye (cf. Scheme 1 and Figure 2). Pyrylium dyes such as $\mathbf{9}$, originally developed for the staining of proteins, ${ }^{43}$ react readily with primary amines at $\mathrm{pH}>8$ to give the corresponding pyridinium adducts (pyridinium-type cyanine dyes), which exhibit a large Stokes' shift and can be excited with an argon laser (488 nm) (cf. Figure S2, Supporting Information). 

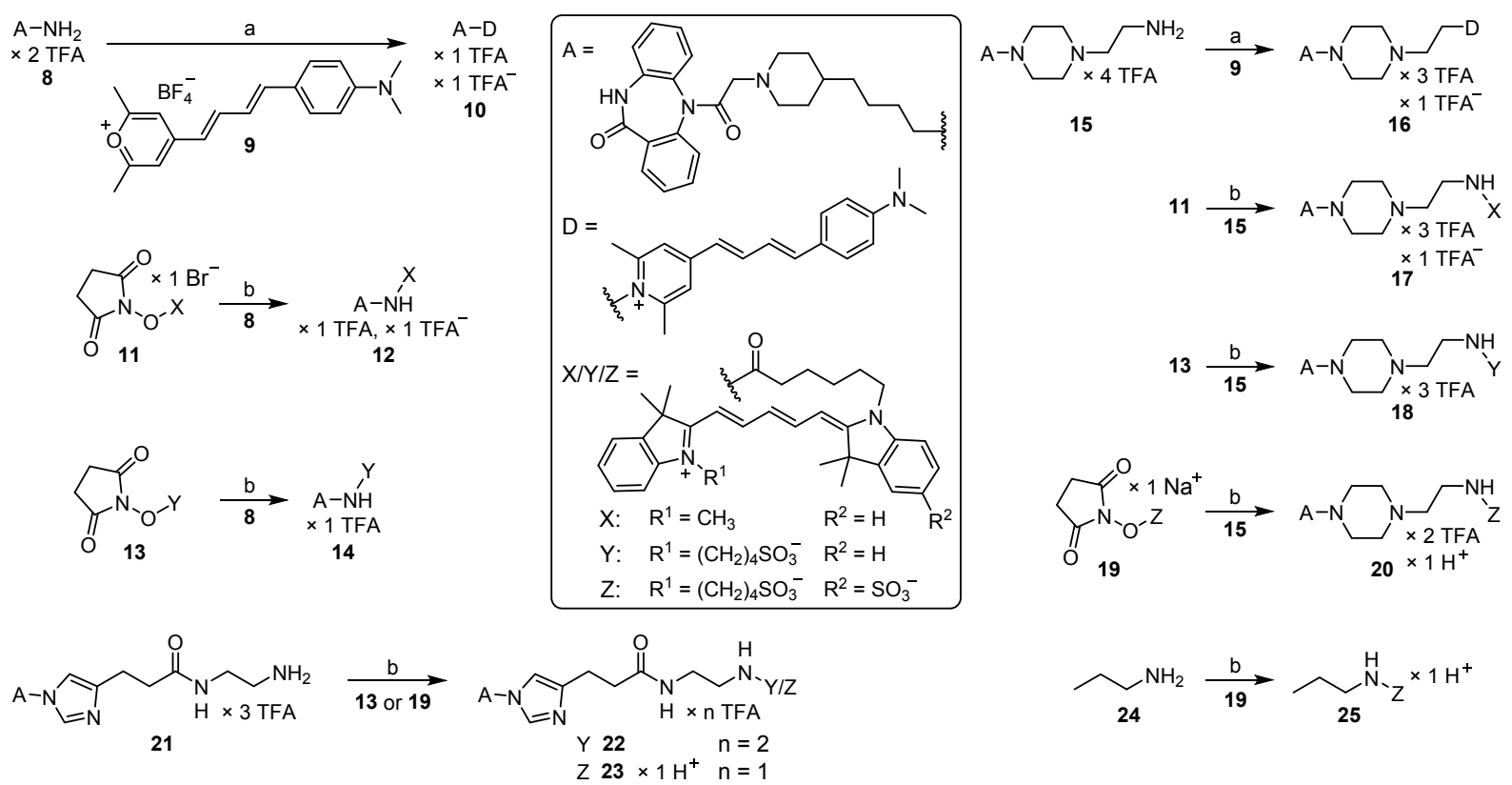<smiles>Cn1cnc(CCC(=O)NCCNC(=O)c2cc(CC[NH3+])cc(C(=O)NCCNC(=O)Cc3cnn(C)c3)c2)c1</smiles>
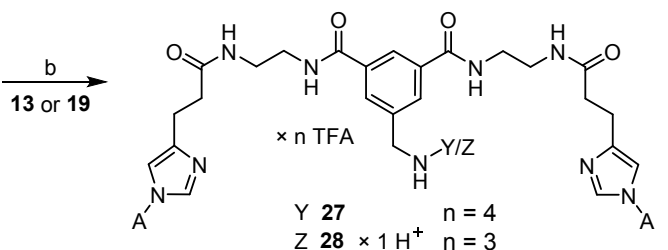<smiles>COC(NCCN1CCN(C)CC1)c1cc(CN)cc(C(=O)NCCN2CCC(N3CCC(n4c(=O)[nH]c5ccccc54)CC3)CC2)c1</smiles><smiles>C[13CH][13CH]</smiles>
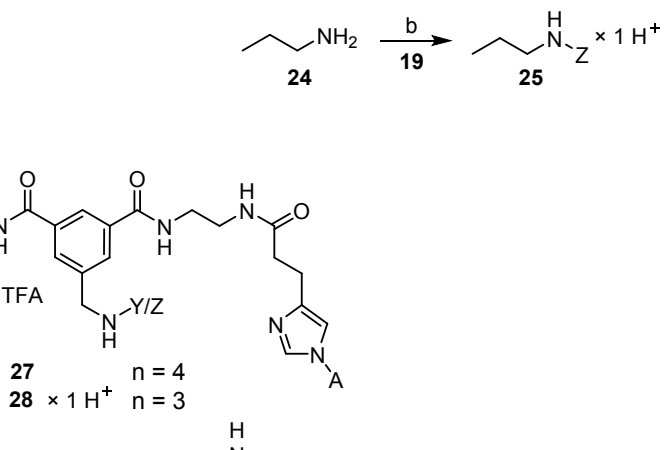

Scheme 1. Synthesis of the red-emitting dibenzodiazepinone-type MR ligands (structures also shown in Figure 2), containing a pyridinium-type $(\mathbf{1 0}, \mathbf{1 6})$ or an indolinium-type $(\mathbf{1 2}, \mathbf{1 4}, \mathbf{1 7}$, 18, 20, 22, 23, 27, 28, 30) cyanine fluorophore, and reference compound 25 . Reagents and conditions: (a) triethylamine, DMF, rt, 2 h, 21\% (10), 34\% (16); (b) DIPEA, DMF, rt, 1-2 h, $40 \%$ (12), 37\% (14), 31\% (17), 30\% (18), 30\% (20), 34\% (22), 41\% (23), 36\% (27), 26\% (28), $34 \%(\mathbf{3 0})$.

Treatment of the amine precursors 8 and $\mathbf{1 5}$ with 9 in the presence of triethylamine yielded the pyridinium-type fluorescent ligands $\mathbf{1 0}$ and 16, respectively (Scheme 1). The cyanine labeled monomeric MR ligands 12, 14, 17, 18, 20, 22 and 23 were prepared by acylation of amines 8 , 
15 and 21 using the succinimidyl esters $\mathbf{1 1}, \mathbf{1 3}$ or 19 (Scheme 1). Reference compound $\mathbf{2 5}^{27}$ was obtained by treatment of propylamine (24) with succinimidyl ester $\mathbf{1 9}$. The homodimeric fluorescent MR ligands $\mathbf{2 7}$ and $\mathbf{2 8}$ were synthesized from amine $\mathbf{2 6}$ and compounds $\mathbf{1 3}$ and $\mathbf{1 9}$, respectively. Treatment of amine precursor 29, containing the pharmacophore of $\mathbf{5}$ and pharmacophoric groups of TBPB, a compound described as an allosteric and bitopic $\mathrm{M}_{1} \mathrm{R}$ ligand, ${ }^{44-47}$ afforded the heterodimeric fluorescent MR ligand 30 (Scheme 1).
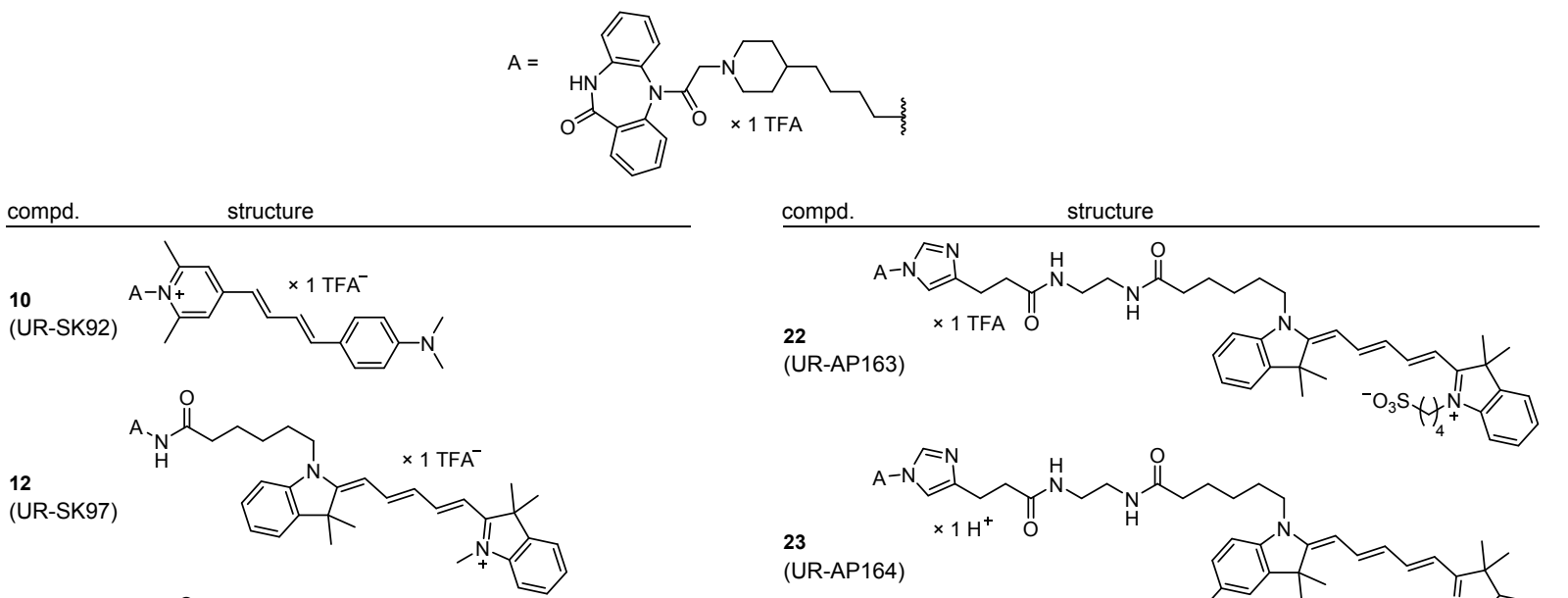

$$
12
$$

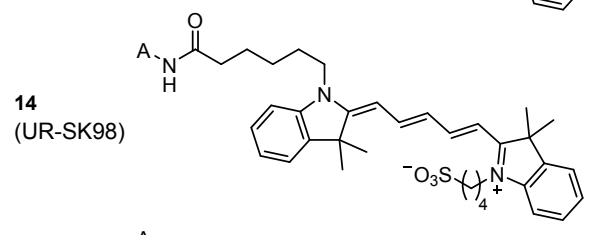

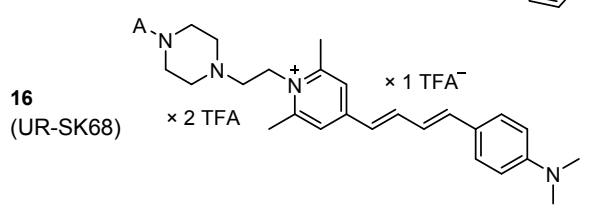
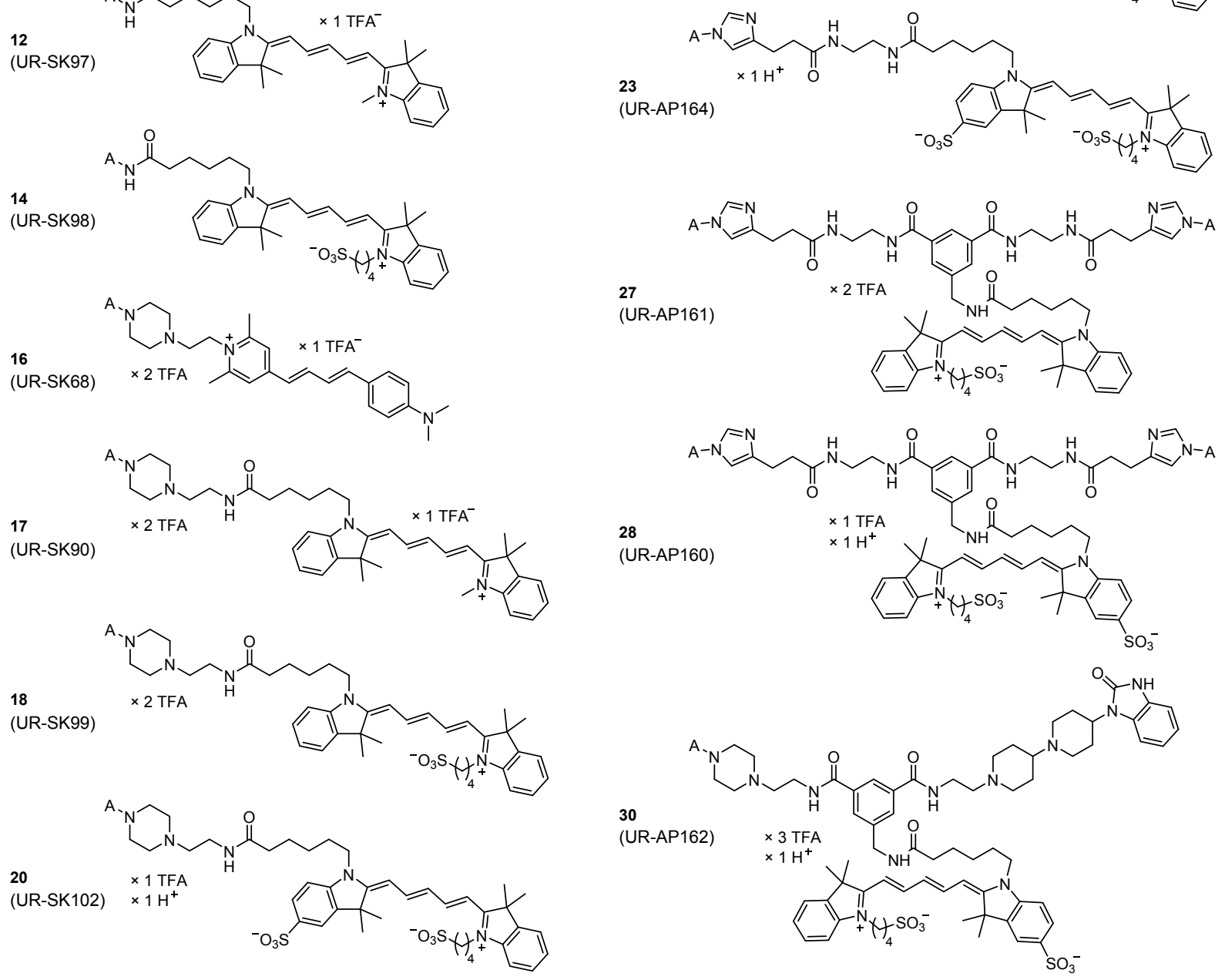

(UR-AP161)
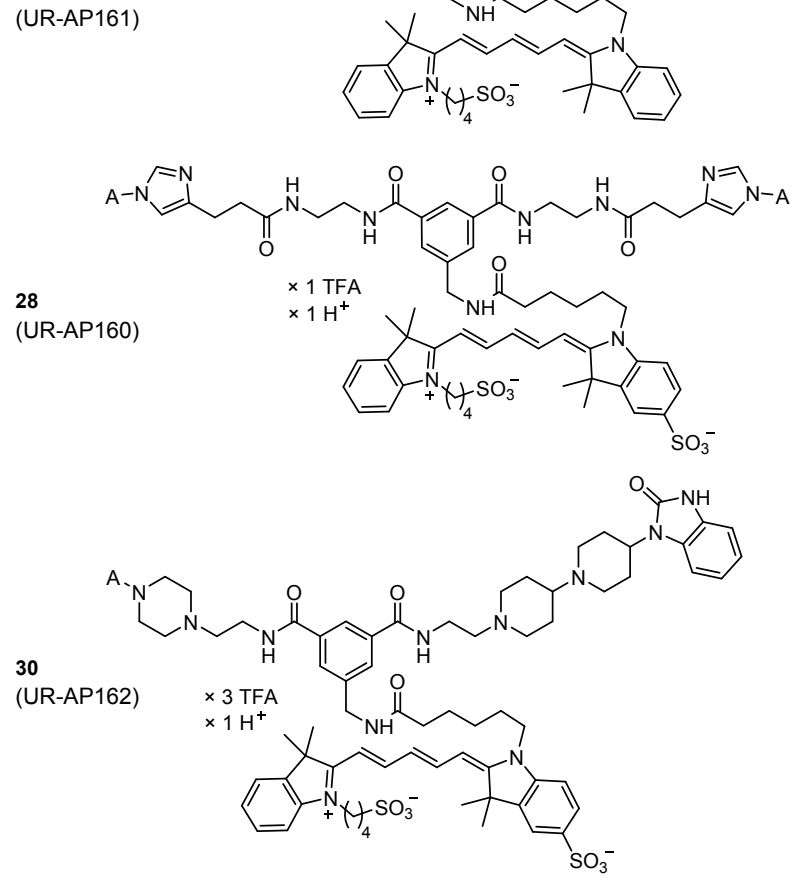

Figure 2. Structures of the synthesized and investigated fluorescent dibenzodiazepinone-type MR ligands. 
The fluorescent ligands $\mathbf{2 0}, \mathbf{2 3}, \mathbf{2 8}$ and $\mathbf{3 0}$ were investigated with respect to their stability under assay-like conditions, i.e. in PBS pH 7.4. In all cases, no decomposition was observed by HPLC analysis within the incubation period of $48 \mathrm{~h}$ (Figure S1, Supporting Information). Interestingly, the vessel material (siliconized glass tube) strongly adsorbed compound $\mathbf{2 8}$, resulting in a reduction of the peak area by approx. 90\% after 24 h (Figure S1C, Supporting Information). Using other materials (polypropylene and "siliconized" polypropylene tubes) did not lower the adsorption of $\mathbf{2 8}$ (data not shown). Likewise, adsorption of $\mathbf{3 0}$ to the vessel material (polypropylene) resulted in a reduction of the peak area by approx. 50\% (Figure S1D). Adsorption of $\mathbf{3 0}$ to a siliconized glass tube was comparable (data not shown). Notably, after removal of the aqueous solution after $48 \mathrm{~h}$, most of $\mathbf{2 8}$ and $\mathbf{3 0}$ could be desorbed and recovered by rinsing of the tube with acetonitrile/0.1\% aq TFA (1:1 v/v) (Figure S1C and S1D, Supporting Information).

Radioligand Competition Binding Studies with $\left[{ }^{3} \mathrm{H}\right]$ NMS. $\mathrm{M}_{1} \mathrm{R}-\mathrm{M}_{5} \mathrm{R}$ affinities of the fluorescently labeled dibenzodiazepinone derivatives $(10,12,14,16-18,20,22,23,27,28$ and 30) were determined at intact $\mathrm{CHO}-\mathrm{hM} \mathrm{M}_{\mathrm{x}} \mathrm{R}$ cells $(\mathrm{x}=1-5)$ using the orthosteric antagonist $\left[{ }^{3} \mathrm{H}\right] \mathrm{NMS}$ as radioligand (for competition binding curves see Figure S2, Supporting Information). The fluorescent ligands with the lowest $\mathrm{M}_{2} \mathrm{R}$ affinities within this series of compounds ( $K_{\mathrm{i}}$ 6.85-8.52; Table 1) contained a fluorophore with positive $(+1)$ net charge $(\mathbf{1 0}$, 12, 16, 17) or no net charge (14). Fluorescent ligands containing a fluorophore with negative $(-1)$ net charge $(\mathbf{2 0}, \mathbf{2 3}, \mathbf{2 8}, \mathbf{3 0})$ exhibited the highest $\mathrm{M}_{2} \mathrm{R}$ affinities $\left(\mathrm{p} K_{\mathrm{i}} 9.10-9.59\right)$. These data suggest that the net charge of the fluorophore has an impact on the $\mathrm{M}_{2} \mathrm{R}$ affinity, becoming obvious, in particular, in case of compounds $17, \mathbf{1 8}$ and 20, which contain the same pharmacophore, linker and fluorophore core structure, but vary with respect to the fluorophore net charge ( $c f$. Figure 2, Table 1). The complete MR selectivity profile was determined for fluorescent ligands 10, 12, 14, 16-18, 20, 23, 28 and 30 (Table 1). Whereas compounds 23 and 
30 exhibited a modest preference for the $M_{2} R$ over the $M_{1}$ and $M_{4}$ receptor, the other compounds proved to be rather non-selective with respect to $M_{1}, M_{2}$ and $M_{4}$ receptor binding (Table 1). A clear $M_{2} R$ over $M_{3} R$ and $M_{5} R$ selectivity was observed for 16, 18, 20, 23, 28 and 30 (difference in $\mathrm{p} K_{\mathrm{i}}>1.5 \log$ units). Some $\left[{ }^{3} \mathrm{H}\right] \mathrm{NMS}$ displacement curves revealed steep curve slopes (for instance, in case of compound $17\left(\mathrm{M}_{2} \mathrm{R}\right)$ : slope $=-2.3$ ), indicating a complex mechanism, e.g., an involvement of more than one binding site, receptor oligomerization or the existence of multiple conformational receptor states. ${ }^{48-51}$ 
Table 1. $\mathrm{M}_{2}$ (and $\mathrm{M}_{1}, \mathrm{M}_{3}-\mathrm{M}_{5}$ ) receptor affinities ( $\mathrm{p} K_{\mathrm{i}}$ values) of the fluorescent DIBA derivatives $10,12,14,16-18,20,22,23,27,28$ and 30 , as well as of the precursor compounds $\mathbf{8}, 15,21,26$ and 29 obtained from equilibrium competition binding studies with $\left[{ }^{3} \mathrm{H}\right] \mathrm{NMS}$ at live $\mathrm{CHO}-\mathrm{hM}_{\mathrm{x}} \mathrm{R}$ cells $(\mathrm{x}=1-5){ }^{a}$

\begin{tabular}{|c|c|c|c|c|c|c|c|c|c|c|}
\hline \multirow{2}{*}{ compd. } & \multicolumn{2}{|c|}{$\mathrm{M}_{1} \mathrm{R}$} & \multicolumn{2}{|c|}{$\mathrm{M}_{2} \mathrm{R}$} & \multicolumn{2}{|c|}{$\mathrm{M}_{3} \mathrm{R}$} & \multicolumn{2}{|c|}{$\mathrm{M}_{4} \mathrm{R}$} & \multicolumn{2}{|c|}{$\mathrm{M}_{5} \mathrm{R}$} \\
\hline & $\mathrm{p} K_{\mathrm{i}}$ & slope $^{b}$ & $\mathrm{p} K_{\mathrm{i}}$ & slope $^{b}$ & $\mathrm{p} K_{\mathrm{i}}$ & slope $^{b}$ & $\mathrm{p} K_{\mathrm{i}}$ & slope $^{b}$ & $\mathrm{p} K_{\mathrm{i}}$ & slope $^{b}$ \\
\hline 8 & - & & $\begin{array}{c}7.97 \pm \\
0.03^{c}\end{array}$ & $\begin{array}{c}-0.98 \pm \\
0.07\end{array}$ & - & & - & & - & \\
\hline 10 & $\begin{array}{c}7.51 \pm \\
0.07\end{array}$ & $\begin{array}{c}-1.5 \pm \\
0.2\end{array}$ & $\begin{array}{c}7.77 \pm \\
0.08\end{array}$ & $\begin{array}{c}-1.2 \pm \\
0.2\end{array}$ & $\begin{array}{c}7.07 \pm \\
0.06\end{array}$ & $\begin{array}{c}-1.3 \pm \\
0.1\end{array}$ & $\begin{array}{c}7.79 \pm \\
0.03\end{array}$ & $\begin{array}{c}-1.3^{ \pm} \\
0.04^{c}\end{array}$ & $\begin{array}{c}6.70 \pm \\
0.06\end{array}$ & $\begin{array}{c}-1.6 \pm \\
0.1^{d}\end{array}$ \\
\hline 12 & $\begin{array}{c}6.92 \pm \\
0.07\end{array}$ & $\begin{array}{c}-1.3 \pm \\
0.1\end{array}$ & $\begin{array}{c}7.27 \pm \\
0.04\end{array}$ & $\begin{array}{c}-1.6 \pm \\
0.2\end{array}$ & $\begin{array}{c}6.20 \pm \\
0.03\end{array}$ & $\begin{array}{c}-1.7 \pm \\
0.1^{d}\end{array}$ & $\begin{array}{c}7.17 \pm \\
0.02\end{array}$ & $\begin{array}{c}-1.4 \pm \\
0.1\end{array}$ & $\begin{array}{c}6.54 \pm \\
0.09\end{array}$ & $\begin{array}{c}-1.7 \pm \\
0.2^{d}\end{array}$ \\
\hline 14 & $\begin{array}{c}6.46 \pm \\
0.04\end{array}$ & $\begin{array}{c}-1.8 \pm \\
0.3\end{array}$ & $\begin{array}{c}6.85 \pm \\
0.07\end{array}$ & $\begin{array}{c}-1.5 \pm \\
0.3\end{array}$ & $\begin{array}{c}6.06 \pm \\
0.12\end{array}$ & $\begin{array}{c}-1.0 \pm \\
0.1\end{array}$ & $\begin{array}{c}6.70 \pm \\
0.06\end{array}$ & $\begin{array}{c}-1.3 \pm \\
0.2\end{array}$ & $\begin{array}{c}6.06 \pm \\
0.12\end{array}$ & $\begin{array}{c}-1.1 \pm \\
0.2\end{array}$ \\
\hline 15 & $\begin{array}{c}8.23 \pm \\
0.11\end{array}$ & $\begin{array}{c}-0.87 \pm \\
0.12\end{array}$ & $\begin{array}{c}9.74 \pm \\
0.09\end{array}$ & $\begin{array}{c}-0.97 \pm \\
0.11\end{array}$ & $\begin{array}{c}6.84 \pm \\
0.08\end{array}$ & $\begin{array}{c}-0.85 \pm \\
0.05\end{array}$ & $\begin{array}{c}9.35 \pm \\
0.09\end{array}$ & $\begin{array}{c}-0.83 \pm \\
0.09\end{array}$ & $\begin{array}{c}6.63 \pm \\
0.03\end{array}$ & $\begin{array}{c}-1.1 \pm \\
0.1\end{array}$ \\
\hline 16 & $\begin{array}{c}7.86 \pm \\
0.04\end{array}$ & $\begin{array}{c}-1.8^{ \pm} \\
0.2^{d}\end{array}$ & $\begin{array}{c}8.52 \pm \\
0.06\end{array}$ & $\begin{array}{c}-1.9 \pm \\
0.3\end{array}$ & $\begin{array}{c}6.83 \pm \\
0.03\end{array}$ & $\begin{array}{c}-1.8 \pm \\
0.02^{d}\end{array}$ & $\begin{array}{c}8.02 \pm \\
0.23\end{array}$ & $\begin{array}{c}-1.4 \pm \\
0.1\end{array}$ & $\begin{array}{c}6.41 \pm \\
0.08\end{array}$ & $\begin{array}{c}-1.3 \pm \\
0.2\end{array}$ \\
\hline 17 & $\begin{array}{c}7.82 \pm \\
0.04\end{array}$ & $\begin{array}{c}-2.1^{ \pm} \\
0.1^{d}\end{array}$ & $\begin{array}{c}8.35 \pm \\
0.04\end{array}$ & $\begin{array}{c}-2.3^{ \pm} \\
0.2^{d}\end{array}$ & $\begin{array}{c}7.07 \pm \\
0.06\end{array}$ & $\begin{array}{c}-1.4 \pm \\
0.1\end{array}$ & $\begin{array}{c}7.73 \pm \\
0.09\end{array}$ & $\begin{array}{c}-1.5 \pm \\
0.1^{d}\end{array}$ & $\begin{array}{c}7.16 \pm \\
0.05\end{array}$ & $\begin{array}{c}-1.5 \pm \\
0.1^{d}\end{array}$ \\
\hline 18 & $\begin{array}{c}8.00 \pm \\
0.10\end{array}$ & $\begin{array}{c}-1.9 \pm \\
0.2^{d}\end{array}$ & $\begin{array}{c}8.87 \pm \\
0.06\end{array}$ & $\begin{array}{c}-1.3 \pm \\
0.2\end{array}$ & $\begin{array}{c}7.17 \pm \\
0.01\end{array}$ & $\begin{array}{c}-1.1 \pm \\
0.03\end{array}$ & $\begin{array}{c}8.40 \pm \\
0.20\end{array}$ & $\begin{array}{c}-1.3 \pm \\
0.1\end{array}$ & $\begin{array}{c}6.85 \pm \\
0.01\end{array}$ & $\begin{array}{c}-1.5 \pm \\
0.1\end{array}$ \\
\hline 20 & $\begin{array}{c}8.54 \pm \\
0.17\end{array}$ & $\begin{array}{c}-1.4 \pm \\
0.2\end{array}$ & $\begin{array}{c}9.28 \pm \\
0.09\end{array}$ & $\begin{array}{c}-1.3 \pm \\
0.1\end{array}$ & $\begin{array}{c}7.09 \pm \\
0.03\end{array}$ & $\begin{array}{c}-0.99 \pm \\
0.12\end{array}$ & $\begin{array}{c}8.67 \pm \\
0.18\end{array}$ & $\begin{array}{c}-1.0 \pm \\
0.1\end{array}$ & $\begin{array}{c}6.87 \pm \\
0.14\end{array}$ & $\begin{array}{c}-0.99 \pm \\
0.16\end{array}$ \\
\hline 21 & - & & $\begin{array}{c}9.23 \pm \\
0.10^{c}\end{array}$ & $\begin{array}{c}-0.82 \pm \\
0.10\end{array}$ & - & & - & & - & \\
\hline 22 & - & & $\begin{array}{c}9.03 \pm \\
0.08\end{array}$ & $\begin{array}{c}-1.4 \pm \\
0.1\end{array}$ & - & & - & & - & \\
\hline 23 & $\begin{array}{c}8.28 \pm \\
0.17\end{array}$ & $\begin{array}{c}-1.3 \pm \\
0.1\end{array}$ & $\begin{array}{c}9.10 \pm \\
0.04\end{array}$ & $\begin{array}{c}-0.99 \pm \\
0.19\end{array}$ & $\begin{array}{c}6.81 \pm \\
0.05\end{array}$ & $\begin{array}{c}-1.3^{ \pm} \\
0.1^{d}\end{array}$ & $\begin{array}{c}8.35 \pm \\
0.19\end{array}$ & $\begin{array}{c}-0.98 \pm \\
0.07\end{array}$ & $\begin{array}{c}6.78 \pm \\
0.24\end{array}$ & $\begin{array}{c}-0.98 \pm \\
0.15\end{array}$ \\
\hline 26 & - & & $\begin{array}{c}9.57 \pm \\
0.07\end{array}$ & $\begin{array}{c}-1.9 \pm \\
0.3\end{array}$ & - & & - & & - & \\
\hline 27 & - & & $\begin{array}{c}8.85 \pm \\
0.07\end{array}$ & $\begin{array}{c}-1.5 \pm \\
0.2\end{array}$ & - & & - & & - & \\
\hline 28 & $\begin{array}{c}8.64 \pm \\
0.03\end{array}$ & $\begin{array}{c}-1.6 \pm \\
0.1^{d}\end{array}$ & $\begin{array}{c}9.20 \pm \\
0.03\end{array}$ & $\begin{array}{c}-1.3 \pm \\
0.1\end{array}$ & $\begin{array}{c}7.12 \pm \\
0.02\end{array}$ & $\begin{array}{c}-1.6 \pm \\
0.2\end{array}$ & $\begin{array}{c}8.54 \pm \\
0.16\end{array}$ & $\begin{array}{c}-1.1 \pm \\
0.1\end{array}$ & $\begin{array}{c}6.39 \pm \\
0.02\end{array}$ & $\begin{array}{c}-1.1 \pm \\
0.4\end{array}$ \\
\hline 29 & $8.79^{e}$ & $-1.2^{e}$ & $9.71^{e}$ & $-1.4^{e}$ & $7.77^{e}$ & $-1.2^{e}$ & - & & - & \\
\hline 30 & $\begin{array}{c}8.64 \pm \\
0.09\end{array}$ & $\begin{array}{c}-1.6 \pm \\
0.3\end{array}$ & $\begin{array}{c}9.59 \pm \\
0.03\end{array}$ & $\begin{array}{c}-1.7 \pm \\
0.2\end{array}$ & $\begin{array}{c}7.66 \pm \\
0.06\end{array}$ & $\begin{array}{c}-1.2 \pm \\
0.2\end{array}$ & $\begin{array}{c}8.59 \pm \\
0.04\end{array}$ & $\begin{array}{c}-1.5 \pm \\
0.3\end{array}$ & $\begin{array}{c}7.51 \pm \\
0.21\end{array}$ & $\begin{array}{c}-0.70 \pm \\
0.09\end{array}$ \\
\hline
\end{tabular}

${ }^{a}$ Presented are mean values \pm SEM from two $\left(\mathbf{2 3}, \mathrm{M}_{5} \mathrm{R}\right)$ or at least three independent experiments (performed in triplicate). $K_{\mathrm{d}}$ values (reported previously ${ }^{42}$ )/applied concentrations of [ $\left.{ }^{3} \mathrm{H}\right] \mathrm{NMS}: \mathrm{M}_{1}, 0.12 / 0.2 \mathrm{nM} ; \mathrm{M}_{2}, 0.090 / 0.2$ $\mathrm{nM} ; \mathrm{M}_{3}, 0.089 / 0.2 \mathrm{nM} ; \mathrm{M}_{4}, 0.035 / 0.1 \mathrm{nM} ; \mathrm{M}_{5}, 0.24 / 0.3 \mathrm{nM}$. ${ }^{b}$ Curve slope of the four-parameter logistic fit. 'Data 
were previously reported as $\mathrm{pIC}_{50}$ values by Keller et al. and were reanalyzed to give $\mathrm{p} K_{\mathrm{i}}$ values. ${ }^{42}{ }^{d}$ Slope different from unity $(\mathrm{P}<0.05) .{ }^{e}$ She $e t a l .39$

$M_{2} R$ antagonism. The fluorescently labeled dibenzodiazepinone derivatives 18, 20, 23 and 28 were investigated in an IP1 accumulation assay at $37^{\circ} \mathrm{C}$ using live HEK-293 cells transiently transfected with the $\mathrm{hM}_{2} \mathrm{R}$ and the hybrid G-protein $\mathrm{G}_{\mathrm{qi}}-\mathrm{HA}{ }^{38,52}$. Compounds 18, 20, 23 and 28 did not elicit IP1 accumulation when studied in agonist mode (Figure 3A). In antagonist mode, 18, 20, 23 and 28 as well as the reference antagonist atropine (31) fully inhibited IP1 accumulation elicited by carbachol $(\mathrm{CCh})\left(0.3 \mu \mathrm{M}, \approx \mathrm{EC}_{80}\right)$ (Figure 3B), demonstrating that the studied fluorescent ligands are $\mathrm{M}_{2} \mathrm{R}$ antagonists. As previously reported for the dibenzodiazepinone-type MR antagonists 6 and 7 (structures $c f$. Figure 1B), the antagonistic potencies of 18, 20, 23 and 28 (Table 2) were considerably lower compared to binding data ( $\mathrm{p} K_{\mathrm{i}}$ values) obtained from radioligand competition binding studies (Table 1). Increasing the incubation times in the $\mathrm{M}_{2} \mathrm{R}$ IP1 assay from $30 \mathrm{~min}$ to $180 \mathrm{~min}$ (preincubation of the cells with antagonist) and from $60 \mathrm{~min}$ to $90 \mathrm{~min}$ (continued incubation after addition of the agonist $\mathrm{CCh}$ ), as well as lowering the temperature from $37{ }^{\circ} \mathrm{C}$ to $22{ }^{\circ} \mathrm{C}$ during preincubation, did not affect $(\mathbf{1 8}, \mathbf{2 8})$ or led to a moderate increase $(\mathbf{2 0}, \mathbf{2 3})$ in $\mathrm{pIC}_{50}$ values (Table 2). Possibly, the type of interaction between $\mathbf{1 8}, \mathbf{2 0}, \mathbf{2 3}$ or $\mathbf{2 8}$ and $\mathrm{CCh}$ is different from how the small antagonist $\mathbf{3 1}$ inhibits the CCh induced IP1 accumulation, which is supported by a much better correlation of the $\mathrm{pIC}_{50}\left(\mathrm{p} K_{\mathrm{b}}\right)$ and $\mathrm{p} K_{\mathrm{i}}$ value in case of $\mathbf{3 1}\left(\mathrm{pIC}_{50}: 8.09\right.$ (Table 2$)$, corresponding $\mathrm{p} K_{\mathrm{b}}: 8.66$, $\mathrm{p} K_{\mathrm{i}}: 9.04$ (Table 6)). Therefore, $\mathrm{p} K_{\mathrm{b}}$ estimates were not calculated for 18, 20, 23 and 28.

The fluorescent ligands 18, 20, 23 and 28 were also investigated in an $M_{4} R$ IP1 accumulation assay using intact HEK-293 cells transiently transfected with the $\mathrm{hM}_{4} \mathrm{R}$ and the hybrid Gprotein $\mathrm{Ga}_{\mathrm{qi}}$ - HA. For these studies, only the aforementioned "long incubation" conditions $\left(M_{2} R\right)$ were applied. 

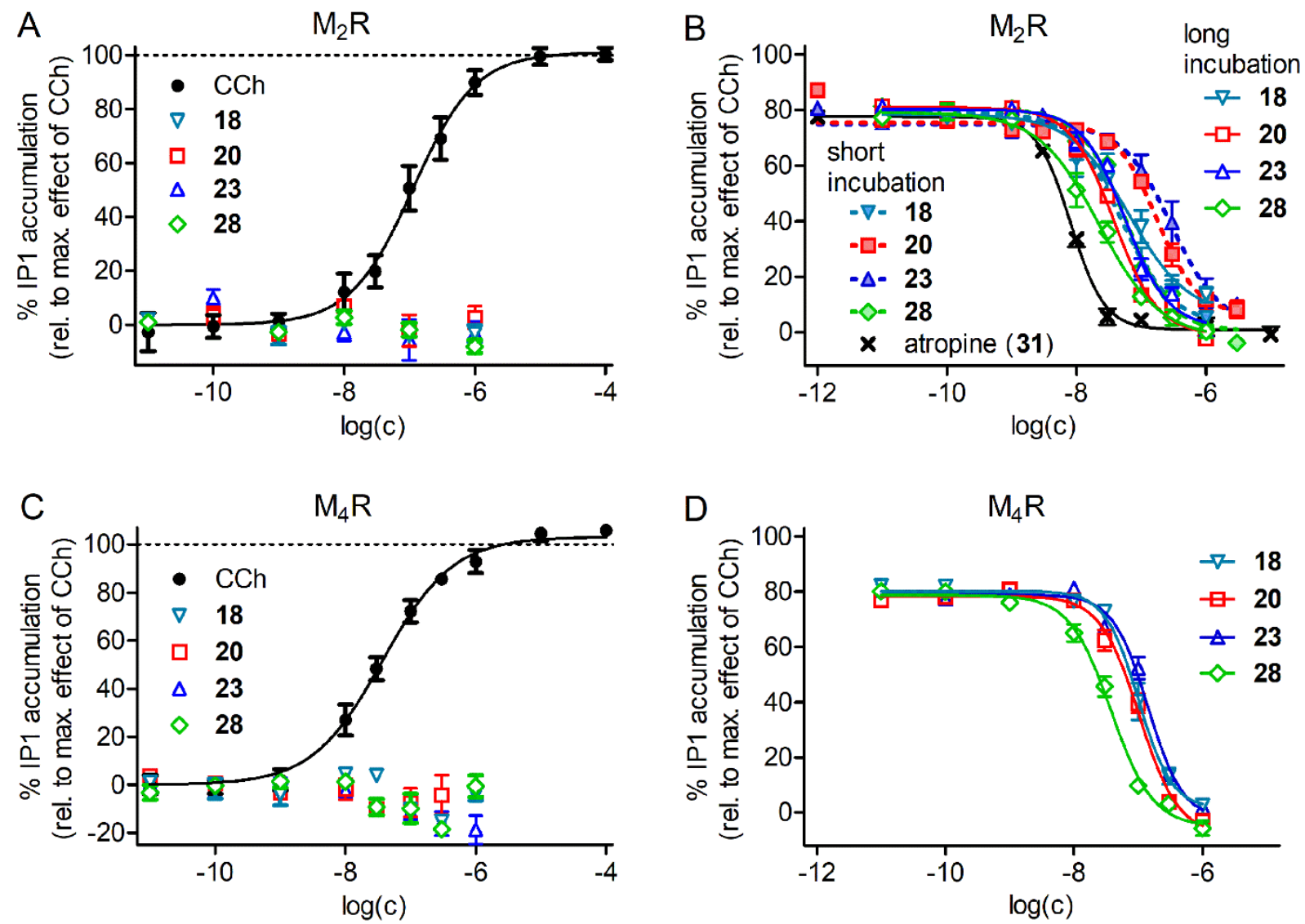

Figure 3. Investigation of $\mathrm{M}_{2} \mathrm{R}$ and $\mathrm{M}_{4} \mathrm{R}$ agonism and antagonism of compounds 18, 20, 23 and 28 in IP1 accumulation assays using HEK-hM ${ }_{2}-\mathrm{G}_{\mathrm{qi}} 5^{-} \mathrm{HA}$ and $\mathrm{HEK}-\mathrm{hM}_{4}-\mathrm{G}_{\mathrm{qi}^{-} 5^{-} \mathrm{HA}}$ cells, respectively. (A) Effect of CCh, 18, 20, 23 and 28 on the $\mathrm{M}_{2} \mathrm{R}$ mediated accumulation of IP1. 18, 20, 23 and 28 elicited no response. Data of CCh represent means \pm SD from 14 independent experiments performed in duplicate. Data of 18, 20, 23 and 28 represent means \pm SEM from three $(\mathbf{2 0}, \mathbf{2 3})$ or four $(\mathbf{1 8}, \mathbf{2 8})$ independent experiments performed in duplicate. $\mathrm{pEC}_{50}$ of $\mathrm{CCh}$ : $6.95 \pm 0.12($ mean $\pm S D, n=14)$. (B) Inhibition of the $\mathrm{CCh}(0.3 \mu \mathrm{M})$ induced IP1 accumulation $\left(\mathrm{M}_{2} \mathrm{R}\right)$ by 18, 20, 23, 28 and atropine ( $\mathrm{pIC}_{50}$ values see Table 2$)$. Cells were either preincubated with the antagonist at $\mathrm{rt}$ for $30 \mathrm{~min}$ followed by addition of $\mathrm{CCh}$ and continued incubation for $60 \mathrm{~min}$ (short incubation) or were preincubated with the antagonist at $22{ }^{\circ} \mathrm{C}$ for $180 \mathrm{~min}$ followed by addition of $\mathrm{CCh}$ and continued incubation at $37^{\circ} \mathrm{C}$ for $90 \mathrm{~min}$ (long incubation). Data represent means \pm SEM (number of individual experiments see Table 2). (C) Effect of CCh, 18, 20, 23 and 28 on the $M_{4} R$ mediated accumulation of IP1. 18, 20, 23 and 28 elicited no response. Data represent means \pm SEM from four $(\mathbf{1 8}, \mathbf{2 0}, \mathbf{2 3}, \mathbf{2 8})$ or six $(\mathrm{CCh})$ independent 
experiments, each performed in duplicate. $\mathrm{pEC}_{50}$ of $\mathrm{CCh}: 7.42 \pm 0.02($ mean $\pm \mathrm{SEM}, \mathrm{n}=6$ ). (D) Inhibition of the CCh $(0.1 \mu \mathrm{M})$ induced IP1 accumulation $\left(\mathrm{M}_{4} \mathrm{R}\right)$ by $\mathbf{1 8 , 2 0 , 2 3 , 2 8}\left(\mathrm{pIC}_{50}\right.$ values see Table 2). Cells were preincubated with the antagonist at $22{ }^{\circ} \mathrm{C}$ for $180 \mathrm{~min}$ followed by addition of $\mathrm{CCh}$ and continued incubation at $37^{\circ} \mathrm{C}$ for $90 \mathrm{~min}$. Data represent means $\pm \mathrm{SEM}$ (number of individual experiments see Table 2).

As in case of the $\mathrm{M}_{2} \mathrm{R}$ IP1 assay, compounds 18, 20, 23 and 28 did not elicit IP1 accumulation when studied in agonist mode (Figure 3C), but completely inhibited IP1 accumulation elicited by carbachol $\left(0.1 \mu \mathrm{M}, \approx \mathrm{EC}_{80}\right)$ when studied in antagonist mode (Figure $\left.3 \mathrm{D}\right)$. The $\mathrm{pIC}_{50}$ values from the $\mathrm{M}_{4} \mathrm{R}$ IP1 assay were marginally lower than the respective $\mathrm{pIC}_{50}$ values obtained from the $M_{2} R$ IP1 assay (Table 2), reflecting lacking $M_{2} R$ selectivity (towards $M_{4} R$ ) identified in radioligand competition binding studies (Table 1).

Table 2. Antagonistic activities of 18, 20, 23 and 28 obtained from $M_{2} R$ and $M_{4} R$ IP1 accumulation assays.

\begin{tabular}{|c|c|c|c|c|c|c|}
\hline \multirow{3}{*}{ compd. } & \multicolumn{4}{|c|}{$\mathrm{M}_{2} \mathrm{R}$} & \multirow{2}{*}{\multicolumn{2}{|c|}{$\frac{\mathrm{M}_{4} \mathrm{R}}{\text { long incubation }}$}} \\
\hline & \multicolumn{2}{|c|}{ short incubation } & \multicolumn{2}{|c|}{ long incubation } & & \\
\hline & $\mathrm{pIC}_{50}{ }^{a}$ & $\mathrm{n}^{b}$ & $\mathrm{pIC}_{50}{ }^{a}$ & $\mathrm{n}^{b}$ & $\mathrm{pIC}_{50}{ }^{c}$ & $\mathrm{n}^{b}$ \\
\hline 18 & $7.31 \pm 0.15$ & 4 & $7.22 \pm 0.12$ & 9 & $7.04 \pm 0.09$ & 8 \\
\hline 20 & $6.65 \pm 0.09$ & 6 & $7.41 \pm 0.05$ & 7 & $6.99 \pm 0.07$ & 6 \\
\hline 23 & $6.45 \pm 0.14$ & 6 & $7.24 \pm 0.05$ & 7 & $6.86 \pm 0.03$ & 6 \\
\hline 28 & $7.62 \pm 0.19$ & 4 & $7.76 \pm 0.12$ & 8 & $7.43 \pm 0.04$ & 10 \\
\hline 31 (atropine) & $8.09 \pm 0.03$ & 5 & n.d. & - & n.d. & - \\
\hline
\end{tabular}

${ }^{a}$ Inhibition of the $\mathrm{CCh}\left(0.3 \mu \mathrm{M}, \approx \mathrm{EC}_{80}\right)$ induced IP1 accumulation in $\mathrm{HEK}-\mathrm{hM}_{2}-\mathrm{Ga}_{\mathrm{qi}}{ }^{-} \mathrm{HA}$ cells. Cells were preincubated with the antagonist at $\mathrm{rt}$ for $30 \mathrm{~min}$ followed by addition of $\mathrm{CCh}$ and continued incubation for $60 \mathrm{~min}$ (short incubation), or were preincubated with the antagonist at $22{ }^{\circ} \mathrm{C}$ for 180 min followed by addition of $\mathrm{CCh}$ and continued incubation at $37^{\circ} \mathrm{C}$ for $90 \mathrm{~min}$ (long incubation). Inhibition curves are shown in Figure 3. Data represent mean values \pm SEM from $\mathrm{n}$ independent experiments. ${ }^{b}$ Number of individual experiments (each performed in duplicate). ${ }^{c}$ Inhibition of the $\mathrm{CCh}$ $\left(0.1 \mu \mathrm{M}, \approx \mathrm{EC}_{80}\right)$ induced IP1 accumulation in $\mathrm{HEK}-\mathrm{hM}_{4}-\mathrm{G}_{\mathrm{qi}}{ }^{-\mathrm{HA}}$ cells. Cells were preincubated with the antagonist at $22{ }^{\circ} \mathrm{C}$ for $180 \mathrm{~min}$ followed by addition of $\mathrm{CCh}$ and continued incubation at $37{ }^{\circ} \mathrm{C}$ for 90 min. Inhibition curves are shown in Figure 3. Data represent mean values \pm SEM from $n$ independent experiments.

n.d.: not determined 
Fluorescence properties. The fluorescence quantum yields were determined (reference: cresyl violet perchlorate) for the fluorescent ligands 16-18, 20, 22, 23 and 28 in PBS (pH 7.4) and in PBS supplemented with $1 \%$ bovine serum albumin (BSA) to estimate the influence of proteins on the quantum yield (Table 3). The selected set of compounds covered all types of fluorophores used in this work. All investigated fluorescent ligands showed a higher quantum yield in PBS supplemented with 1\% BSA compared to PBS alone (Table 3). This phenomenon was previously observed for fluorescently labeled NPY $\mathrm{Y}_{1}$ and $\mathrm{Y}_{4}$ receptor ligands, too, ${ }^{12,14}$ and can be explained by interactions (hydrophobic, electrostatic) of the fluorophores with the protein, resulting in a changed chemical environment and reduced molecular motion (increased rigidity) of the fluorophore.

Table 3. Fluorescence properties of the MR ligands 16-18, 20, 22, 23 and 28 in PBS and PBS containing 1\% BSA: excitation/emission maxima and fluorescent quantum yields $\Phi$ (reference: cresyl violet perchlorate).

\begin{tabular}{cccccc}
\hline \multirow{2}{*}{ compd. $\begin{array}{c}\text { type/net charge of } \\
\text { cyanine dye }(c f . \text { Figure 2) }\end{array}$} & \multicolumn{2}{c}{ PBS } & \multicolumn{2}{c}{ PBS + 1\% BSA } \\
\cline { 3 - 6 } & $\lambda_{\text {ex }} / \lambda_{\text {em }}[\mathrm{nm}]$ & $\Phi(\%)$ & $\lambda_{\text {ex }} / \lambda_{\text {em }}[\mathrm{nm}]$ & $\Phi(\%)$ \\
\hline $\mathbf{1 6}$ & pyridinium/+1 & $460 / 713$ & 8.9 & $484 / 643$ & 23.8 \\
$\mathbf{1 7}$ & indolinium/+1 & $645 / 663$ & 19.1 & $655 / 675$ & 42.1 \\
$\mathbf{1 8}$ & indolinium/0 & $648 / 665$ & 20.9 & $660 / 678$ & 30.1 \\
$\mathbf{2 0}$ & indolinium/-1 & $653 / 669$ & 17.7 & $656 / 672$ & 29.0 \\
$\mathbf{2 2}$ & indolinium/0 & $645 / 666$ & 24.4 & $663 / 676$ & 51.1 \\
$\mathbf{2 3}$ & indolinium/-1 & $651 / 669$ & 21.6 & $658 / 673$ & 36.8 \\
$\mathbf{2 8}$ & indolinium/-1 & $650 / 668$ & $-a$ & $658 / 673$ & 43.4 \\
\hline
\end{tabular}

${ }^{a}$ Due to the strong adsorption of $\mathbf{2 8}$ to the cuvette when dissolved in PBS without BSA, the determination of $\Phi$ failed.

Excitation and corrected emission spectra of 16-18, 20, 22, 23 and 28 in PBS containing 1\% BSA (Figure S2, Supporting Information) revealed that the pyridinium-type fluorescent ligand 16 can be excited with an argon laser and the indolinium-type cyanine dye labeled compounds $(\mathbf{1 7}, \mathbf{1 8}, \mathbf{2 0}, \mathbf{2 2}, \mathbf{2 3}$ and $\mathbf{2 8})$ are suited for an excitation with a red diode laser $(635 \mathrm{~nm})$. 
Flow cytometric binding studies. The fluorescent ligands 18, 20, 23, 28 and 30 were applied in flow cytometric saturation binding studies using intact $\mathrm{CHO}-\mathrm{hM}_{2} \mathrm{R}$ cells. The obtained $\mathrm{p} K_{\mathrm{d}}$ values of $8.59,9.05,8.35,8.51$ and 9.19, respectively (Table 4), were in good agreement with the binding data from competition binding studies with $\left[{ }^{3} \mathrm{H}\right] \mathrm{NMS}$ ( $c f$. Table 1). At concentrations corresponding to the $K_{\mathrm{d}}$ value, unspecific binding was around $10 \%(\mathbf{1 8}, \mathbf{2 0}, \mathbf{2 3}$, 30) or below 5\% (28) of totally bound fluorescent ligand (Figure 4). The saturation binding experiments revealed that $18,20,23,28$ and 30 bind to the orthosteric binding site of the $\mathrm{hM}_{2} \mathrm{R}$, because the orthosteric antagonist atropine (31) (for structure see Figure S4, Supporting Information), used to determine unspecific binding, was capable of completely preventing onesite (monophasic) specific $\mathrm{M}_{2} \mathrm{R}$ binding of these fluorescent ligands. Saturation binding experiments with $\mathbf{2 0}$ were also performed at $\mathrm{CHO}-\mathrm{hM}_{1} \mathrm{R}$ and $\mathrm{CHO}-\mathrm{hM} \mathrm{M}_{4} \mathrm{R}$ cells, yielding $\mathrm{p} K_{\mathrm{d}}$ values of 8.19 and 8.02, respectively (Table 4; Figure S5, Supporting Information), which were again in good accordance with binding data from radioligand competition binding studies ( $c f$. Table 1). 

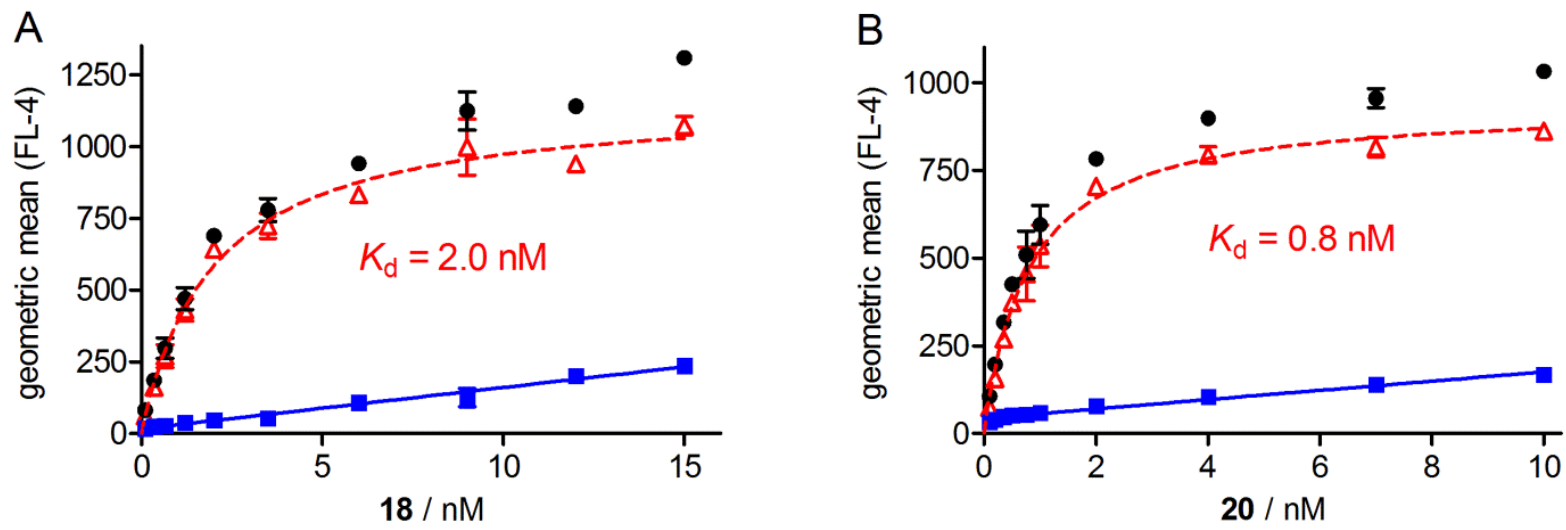

- total binding $\quad$ u unspecific binding $\Delta$ specific binding
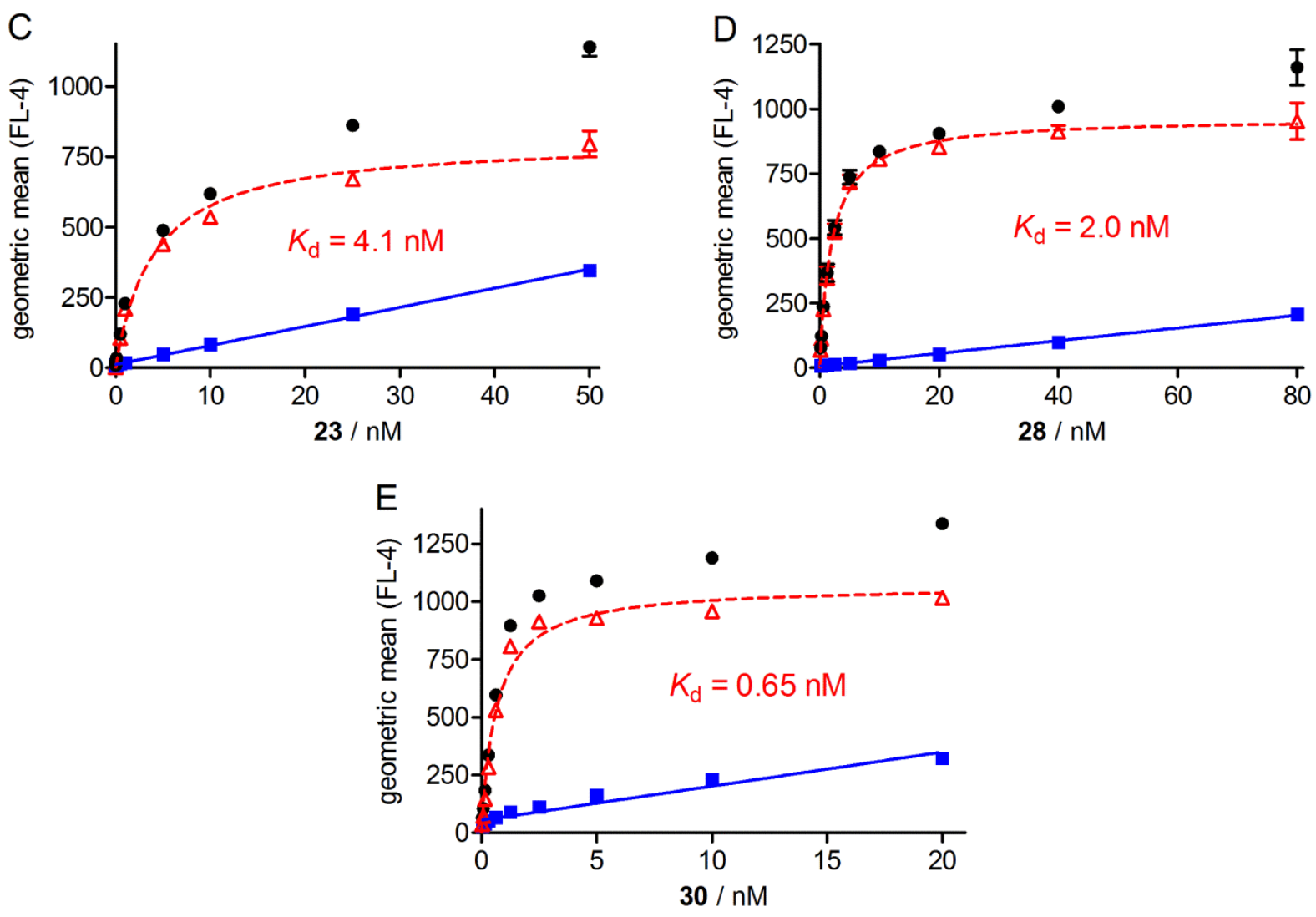

Figure 4. Representative saturation isotherms (specific binding, dashed line) obtained from flow cytometric saturation binding experiments performed with 18 (A), 20 (B), 23 (C), 28 (D) and 30 (E) at intact $\mathrm{CHO}-\mathrm{hM}_{2} \mathrm{R}$ cells. Unspecific binding was determined in the presence of atropine (31, for structure see Figure S4, Supporting Information) (500-fold excess to 18, 20, 23, 28 or 30). Cells were incubated with the fluorescent ligands at $22{ }^{\circ} \mathrm{C}$ in the dark for $2 \mathrm{~h}$ (experiments performed in duplicate). Measurements were performed with a FACSCalibur flow cytometer (Becton Dickinson). In the case of total and unspecific binding, data represent mean 
values \pm SEM. In the case of specific binding, data represent calculated values \pm propagated error.

Table 4. $M_{1} R$ binding data of 20,23 and $28, M_{2} R$ binding data of $18,20,23,28$ and 30 , and $M_{4} R$ binding data of $\mathbf{2 0}$ determined by saturation binding.

\begin{tabular}{|c|c|c|c|}
\hline \multirow{2}{*}{$\begin{array}{c}\text { fluorescent } \\
\text { ligand }\end{array}$} & \multicolumn{3}{|c|}{$\mathrm{p} K_{\mathrm{d}}{ }^{a}$ (flow cytometry) } \\
\hline & $\mathrm{hM}_{1} \mathrm{R}$ & $\mathrm{hM}_{2} \mathrm{R}$ & $\mathrm{hM}_{4} \mathrm{R}$ \\
\hline 18 & - & $8.59 \pm 0.09$ & - \\
\hline 20 & $8.19 \pm 0.02$ & $9.05 \pm 0.04$ & $8.02 \pm 0.03$ \\
\hline 23 & - & $8.35 \pm 0.06$ & - \\
\hline 28 & - & $8.51 \pm 0.08$ & - \\
\hline \multirow[t]{3}{*}{30} & - & $9.19 \pm 0.02$ & - \\
\hline & \multicolumn{3}{|c|}{$\mathrm{p} K_{\mathrm{d}}{ }^{a}$ (high-content imaging) } \\
\hline & $\mathrm{hM}_{1} \mathrm{R}$ & $\mathrm{hM}_{2} \mathrm{R}$ & - \\
\hline 18 & - & $8.06 \pm 0.04$ & \\
\hline 20 & - & $8.33 \pm 0.03$ & \\
\hline 23 & $7.58 \pm 0.04$ & $7.94 \pm 0.02$ & \\
\hline 28 & $8.00 \pm 0.05$ & $8.25 \pm 0.04$ & \\
\hline
\end{tabular}

${ }^{a}$ Determined by saturation binding at intact $\mathrm{CHO}^{-\mathrm{hM}_{\mathrm{x}} \mathrm{R}}$ cells $(\mathrm{x}=1,2,4)$ at $22{ }^{\circ} \mathrm{C}$ using a FACSCalibur flow cytometer or an IX Ultra Confocal Plate Reader (highcontent imaging); mean values $\pm \mathrm{SEM}\left(\mathrm{p} K_{\mathrm{d}}\right)$ from at least two independent experiments performed in duplicate (flow cytometry) or triplicate (high-content imaging).

The association and dissociation kinetics of $\mathbf{2 0}, \mathbf{2 3}$ and $\mathbf{2 8}$ were determined by flow cytometry at intact $\mathrm{CHO}-\mathrm{hM}_{2} \mathrm{R}$ cells at $22{ }^{\circ} \mathrm{C}$ using ligand concentrations which corresponded approximately to the $K_{\mathrm{d}}$ values of $\mathbf{2 0}, \mathbf{2 3}$ and $\mathbf{2 8}$ determined by flow cytometry at $\mathrm{CHO}-\mathrm{hM}_{2} \mathrm{R}$ cells (cf. Table 4). The association of $\mathbf{2 0 ,} \mathbf{2 3}$ and $\mathbf{2 8}$ to the $\mathrm{M}_{2} \mathrm{R}$ appeared to be monophasic (Figure $5, k_{\text {obs }}$ and $k_{\text {on }}$ values summarized in Table 5). For $\mathrm{M}_{2} \mathrm{R}$ dissociation studies with 20, 23 and 28, cells were preincubated with the fluorescent ligand for 180, 120 and $110 \mathrm{~min}$, respectively, applying ligand concentrations corresponding approximately to three times the $K_{\mathrm{d}}$. The dissociations of $\mathbf{2 0 ,} \mathbf{2 3}$ and $\mathbf{2 8}$ were followed over $9 \mathrm{~h}$. Data analysis by a three-parameter 
equation described an incomplete monophasic decline ( $k_{\text {off }}$ values given in Table 5$)$. The dissociation plateaus were different from zero (one-tailed t-test, $\mathrm{P}<0.05(\mathbf{2 0}, \mathbf{2 3})$ or $<0.02$ (28)), indicating a minor component of long lasting $\mathrm{M}_{2} \mathrm{R}$ binding of the studied fluorescent ligands (observed plateau values: 23\%, 5\% and 22\%, respectively; Figure 5). Such a phenomenon can be explained by conformational adjustments of the receptor upon ligand binding ${ }^{53}$ or by an enhanced rebinding mediated by a simultaneous interaction with more than one binding site. ${ }^{54}$ The kinetically derived dissociation constants $K_{\mathrm{d}}(\mathrm{kin})$ of $\mathbf{2 0 ,} \mathbf{2 3}$ and $\mathbf{2 8}$ were in good agreement with the $K_{\mathrm{d}}$ values obtained from flow cytometric saturation binding studies (Table 5).

Compound 23, showing the fastest dissociation of the studied ligands $(\mathbf{2 0}, \mathbf{2 3}, \mathbf{2 8})$ was chosen to perform dissociation experiments in the presence of the allosteric $\mathrm{M}_{2} \mathrm{R}$ modulators W84 (32), ${ }^{55-57}$ LY2119620 (33) ${ }^{58,59}$ or alcuronium (34) ${ }^{60,61}$ (Structures see Figure S4, Supporting Information). The allosteric ligands, used at a high concentration of $100 \mu \mathrm{M}$, did not reduce the observed dissociation rate of $\mathbf{2 3}$ from the $\mathrm{M}_{2} \mathrm{R}$ as previously observed for the structurally related radioligands $\left[{ }^{3} \mathrm{H}\right] 6$ and $\left[{ }^{3} \mathrm{H}\right] 7 .{ }^{38}$ These results are consistent with competitive interactions and an overlapping binding site between 23 and the allosteric modulators 32-34. They suggest a dualsteric binding mode of $\mathbf{2 3}$ to the orthosteric and allosteric pocket at the $\mathrm{M}_{2} \mathrm{R}$, and by implication a similar mode of action for the structurally related fluorescent $M_{2} R$ ligands $\mathbf{1 0}, \mathbf{1 2}$, 14, 16-18, 20, 22, 27, 28 and 30. 

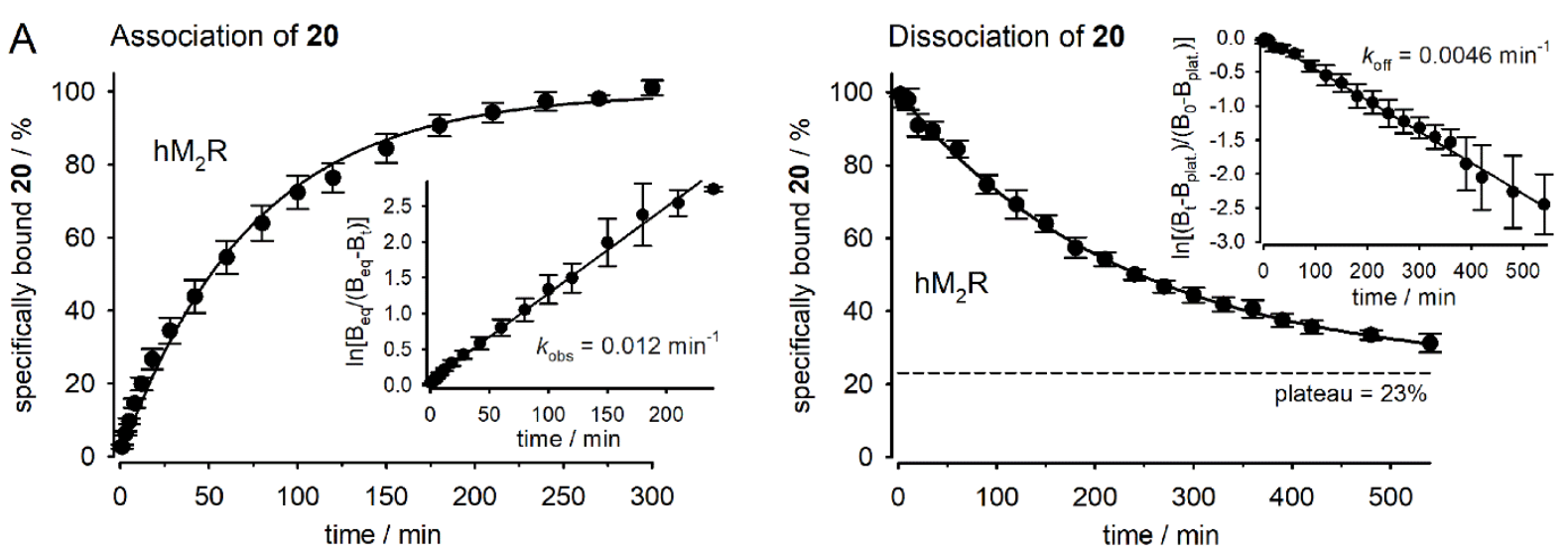

B Association of $\mathbf{2 3}$

Dissociation of 23

determined in the presence of:

- $15 \mu \mathrm{M} 31$

ㅁ $15 \mu \mathrm{M} 31+100 \mu \mathrm{M} 32$ (W84)

$\mathrm{hM}_{2} \mathrm{R}$

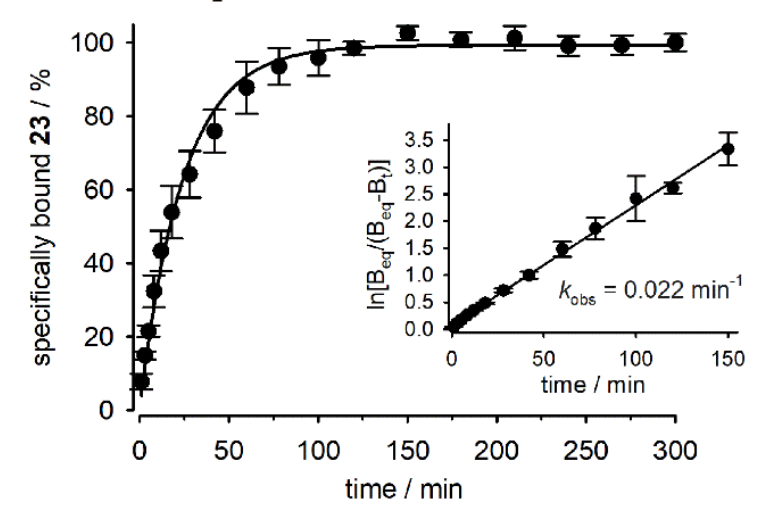

$\Delta 15 \mu \mathrm{M} 31+100 \mu \mathrm{M} 33$ (LY2119620)

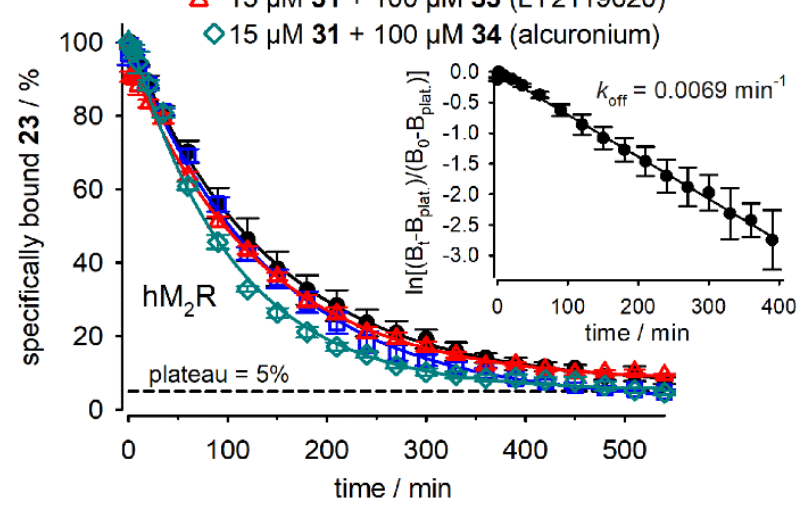

C $\quad$ Association of $\mathbf{2 8}$
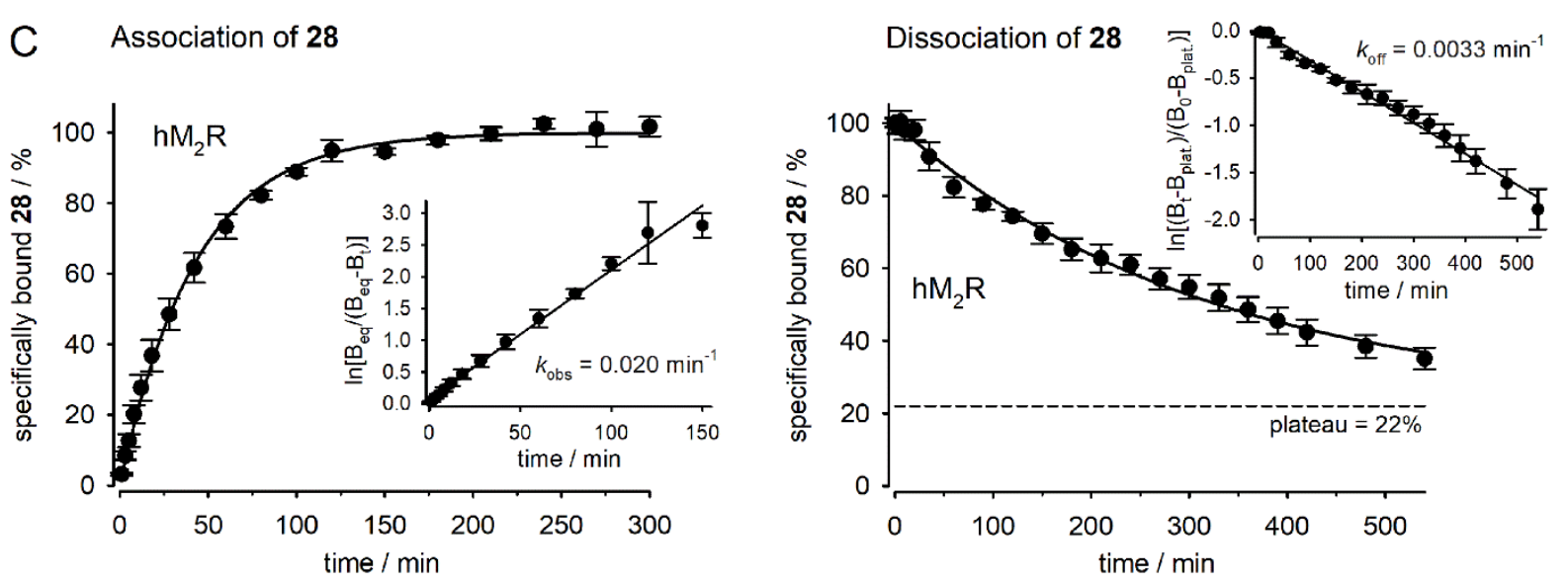

Figure 5. Association and dissociation kinetics of $\mathbf{2 0}$ (panel A), 23 (panel B) and $\mathbf{2 8}$ (panel C) determined by flow cytometry at intact $\mathrm{CHO}-\mathrm{hM}_{2} \mathrm{R}$ cells at $22{ }^{\circ} \mathrm{C}$. The dissociation was determined in the presence of an excess of atropine (31). (A, left) Association of $20(1 \mathrm{nM})$ to the $\mathrm{M}_{2} \mathrm{R}$; inset: $\ln \left[\mathrm{B}_{\mathrm{eq}} /\left(\mathrm{B}_{\mathrm{eq}}-\mathrm{B}_{\mathrm{t}}\right)\right]$ versus time. (A, right) Dissociation of 20 (preincubation: $3 \mathrm{nM}$, $180 \mathrm{~min}$ ) from the $\mathrm{M}_{2} \mathrm{R}$. (B, left) Association of $23(5 \mathrm{nM})$ to the $\mathrm{M}_{2} \mathrm{R}$; inset: $\ln \left[\mathrm{B}_{\mathrm{eq}} /\left(\mathrm{B}_{\mathrm{eq}}-\mathrm{B}_{\mathrm{t}}\right)\right]$ 
versus time. (B, right) Dissociation of 23 (preincubation: $15 \mathrm{nM}, 120 \mathrm{~min}$ ) from the $\mathrm{M}_{2} \mathrm{R}$. Addition of the allosteric $\mathrm{M}_{2} \mathrm{R}$ modulators $\mathbf{3 2}, \mathbf{3 3}$ or $\mathbf{3 4}$ at a high concentration $(100 \mu \mathrm{M})$ did not slow down the dissociation of $\mathbf{2 3}$ indicating a competitive mechanism between $\mathbf{2 3}$ and the allosteric $M_{2} R$ ligands. (C, left) Association of $28(3.5 \mathrm{nM})$ to the $\mathrm{M}_{2} R$; inset: $\ln \left[\mathrm{B}_{\mathrm{eq}} /\left(\mathrm{B}_{\mathrm{eq}}-\mathrm{B}_{\mathrm{t}}\right)\right]$ versus time. (C, right) Dissociation of 28 (preincubation: $10 \mathrm{nM}, 110 \mathrm{~min}$ ) from the $\mathrm{M}_{2} \mathrm{R}$. Data in A-C represent the mean \pm SEM from three or four independent experiments (performed in duplicate). Dissociation data were analyzed by a three-parameter equation describing an incomplete monophasic decline because the curve plateau mean values $(23 \%, 5 \%$ and $22 \%$, respectively) from individual experiments (analyzed by a three-parameter equation) were different from zero $(\mathrm{P}<0.05,<0.05$ and $<0.02$, respectively). The association and dissociation rate constants derived from non-linear curve fitting are summarized in Table 5.

Table 5. Parameters characterizing the association of $\mathbf{2 0 , 2 3}$ and $\mathbf{2 8}$ to, and their dissociation from the $\mathrm{hM}_{2} \mathrm{R}$, determined at CHO-hM $\mathrm{h}_{2} \mathrm{R}$ cells at $22 \pm 1{ }^{\circ} \mathrm{C}$.

\begin{tabular}{cccccc}
\hline compd. & $K_{\mathrm{d}}(\mathrm{sat})[\mathrm{nM}]^{a}$ & $K_{\mathrm{d}}(\mathrm{kin})[\mathrm{nM}]^{b}$ & $k_{\mathrm{obs}}\left[\mathrm{min}^{-1}\right]^{c}$ & $k_{\mathrm{on}}\left[\mathrm{min}^{-1} \cdot \mathrm{nM}^{-1}\right]^{d}$ & $k_{\text {off }}\left[\mathrm{min}^{-1}\right]^{e}$ \\
\hline $\mathbf{2 0}$ & 0.91 & $0.48 \pm 0.22$ & $0.014 \pm 0.002$ & $0.0095 \pm 0.0028$ & $0.0045 \pm 0.0007$ \\
$\mathbf{2 3}$ & 4.6 & $1.9 \pm 0.6$ & $0.026 \pm 0.001$ & $0.0037 \pm 0.0005$ & $0.0069 \pm 0.0011$ \\
$\mathbf{2 8}$ & 3.2 & $1.4 \pm 0.5$ & $0.024 \pm 0.003$ & $0.0049 \pm 0.0011$ & $0.0031 \pm 0.0004$
\end{tabular}

${ }^{a}$ Dissociation constant (given for comparison with $K_{\mathrm{d}}(\mathrm{kin})$ ) determined by flow cytometric saturation binding at $\mathrm{CHO}-\mathrm{hM}_{2} \mathrm{R}$ cells (data taken from Table 4). ${ }^{b}$ Kinetically derived dissociation constant ( \pm propagated error) calculated from $k_{\text {on }}$ and $k_{\text {off. }}{ }^{c}$ Observed association rate constant obtained from two-parameter non-linear fits (exponential rise to a maximum); mean values \pm SEM from three $(\mathbf{2 3}, \mathbf{2 8})$ or four $(\mathbf{2 0})$ independent experiments performed in duplicate. ${ }^{d}$ Association rate constant \pm propagated error, calculated from $k_{\text {obs }}, k_{\text {off }}$ and the applied radioligand concentration ( $c f$. Figure 5 and experimental section). ${ }^{e}$ Dissociation rate constant obtained from threeparameter non-linear fits (incomplete monophasic exponential decline); mean \pm SEM from three (20, 28) or four (23) independent experiments performed in duplicate.

Confocal microscopy. Binding studies with compounds 20, 23 and 28 at live CHO-hM 2 R cells, using confocal microscopy, revealed a marked difference between total and unspecific binding in all cases (Figure 6). Over the whole incubation period (45 min), the major fraction of detected 
fluorescence appeared to be associated with the plasma membrane, and a substantial increase in intracellular fluorescence over time was not observed.

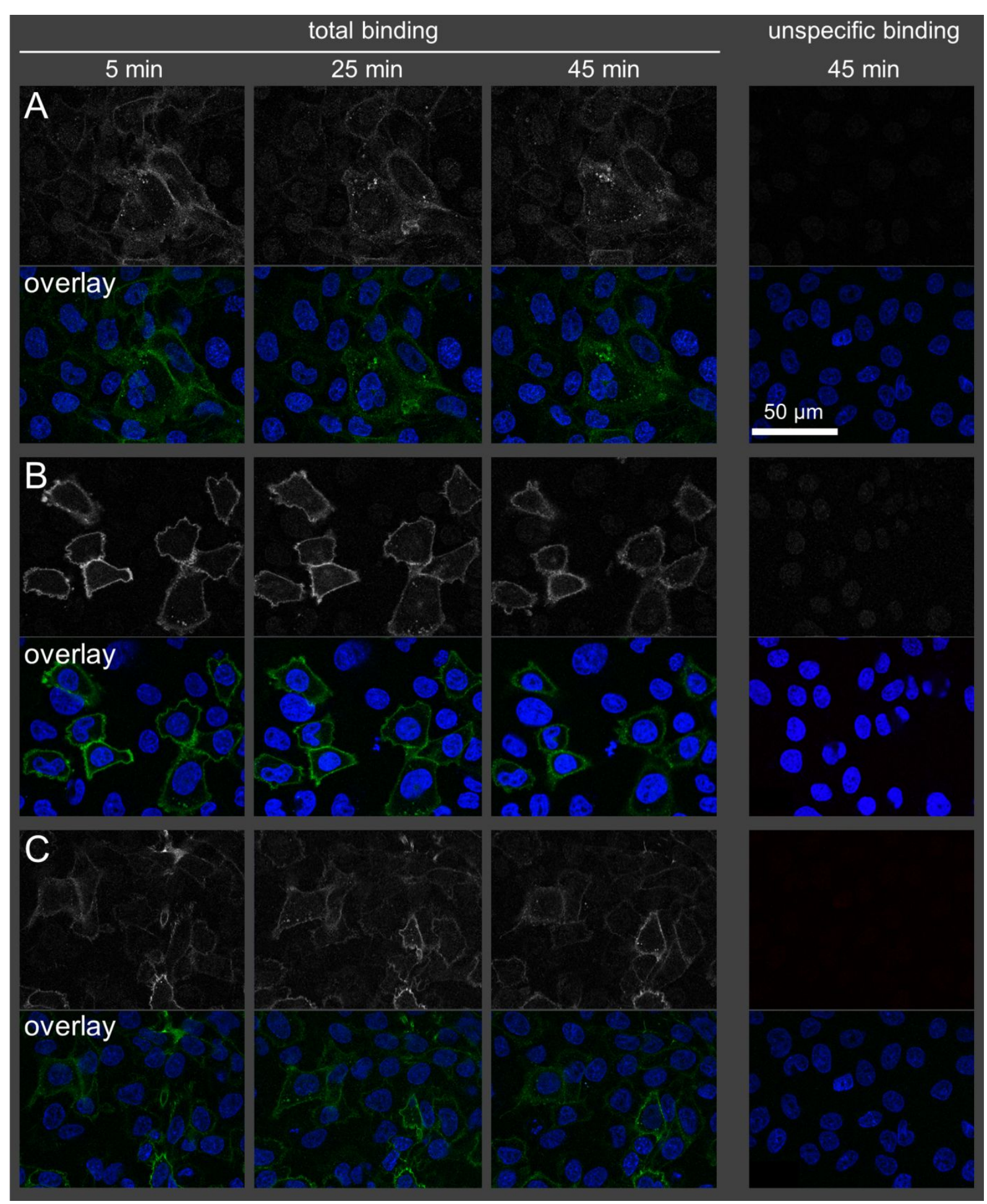

Figure 6. Binding of the fluorescent ligands 20 (A), 23 (B) and 28 (C) (each $30 \mathrm{nM}$ ) to live $\mathrm{CHO}-\mathrm{hM}_{2} \mathrm{R}$ cells at $30{ }^{\circ} \mathrm{C}$, visualized by confocal microscopy (excitation: $633 \mathrm{~nm}$, emission: 
638-759 $\mathrm{nm}$ ) after 5, 25 and $45 \mathrm{~min}$. Unspecific binding was determined in the presence of atropine $(\mathbf{3 1}, 10 \mu \mathrm{M})$. Upper panels show ligand fluorescence alone (greyscale) and overlay panels merge ligand fluorescence (green) and nuclei (blue). Images (representative of at least three experiments) were acquired with a Zeiss LSM 710 confocal microscope.

High-content imaging. The fluorescent ligands 18, 20, 23 and 28 were also applied in highcontent imaging binding assays, allowing a higher sample throughput compared to flow cytometers. In order to reduce background fluorescence, a wash step was performed immediately before measurement (exemplified for $\mathbf{2 3}$ in Figure S8, Supporting Information) Saturation binding experiments with 18, 20, 23 and 28 at live $\mathrm{CHO}-\mathrm{hM}_{2} \mathrm{R}$ cells revealed $\mathrm{p} K_{\mathrm{d}}$ values $\left(8.06,8.33,7.94\right.$ and 8.25 , respectively), which were slightly lower compared to $\mathrm{p} K_{\mathrm{d}}$ values obtained by flow cytometric saturation binding studies (Table 4, Figure 7). These deviations might be attributed to the different techniques used, requiring different types of fluorescence analysis (flow cytometry: analysis of single, suspended cells passing a laser beam; high-content imaging: acquisition of fluorescence images of adherent cells, fluorescence quantification by granularity analysis). Moreover, in case of high-content imaging, high unspecific binding at higher fluorescent ligand concentrations (cf. Figure S8, Supporting Information) might affect the free concentration of fluorescent ligand, resulting in lower apparent $\mathrm{p} K_{\mathrm{d}}$ values.

In addition to $\mathrm{M}_{2} \mathrm{R}$ binding studies, saturation binding experiments with $\mathbf{2 3}$ and $\mathbf{2 8}$ were performed at $\mathrm{CHO}-\mathrm{hM}_{1} \mathrm{R}$ cells (Figure $\mathrm{S} 6$, Supporting Information) yielding $\mathrm{p} K_{\mathrm{d}}$ values of 7.58 and 8.00, respectively (Table 4). Binding experiments with reference compound 25 at CHO$\mathrm{hM}_{2} \mathrm{R}$ cells revealed that the fluorescent dye itself was not capable of staining the cells (Figure S9, Supporting Information). 

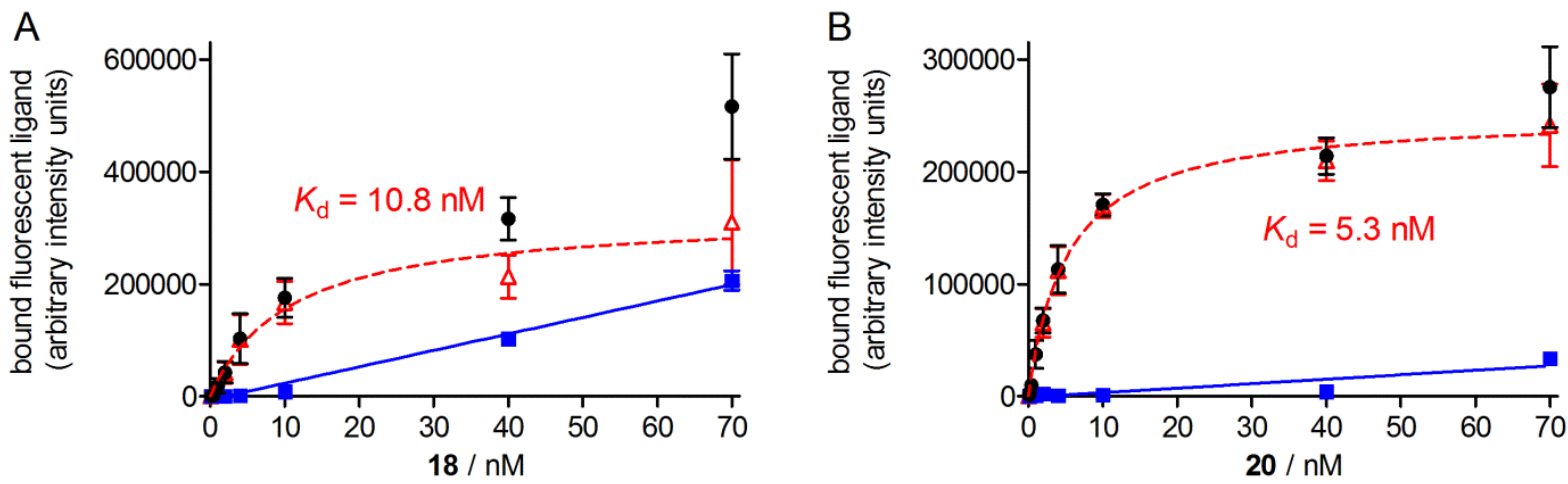

- total binding unspecific binding $\Delta$ specific binding
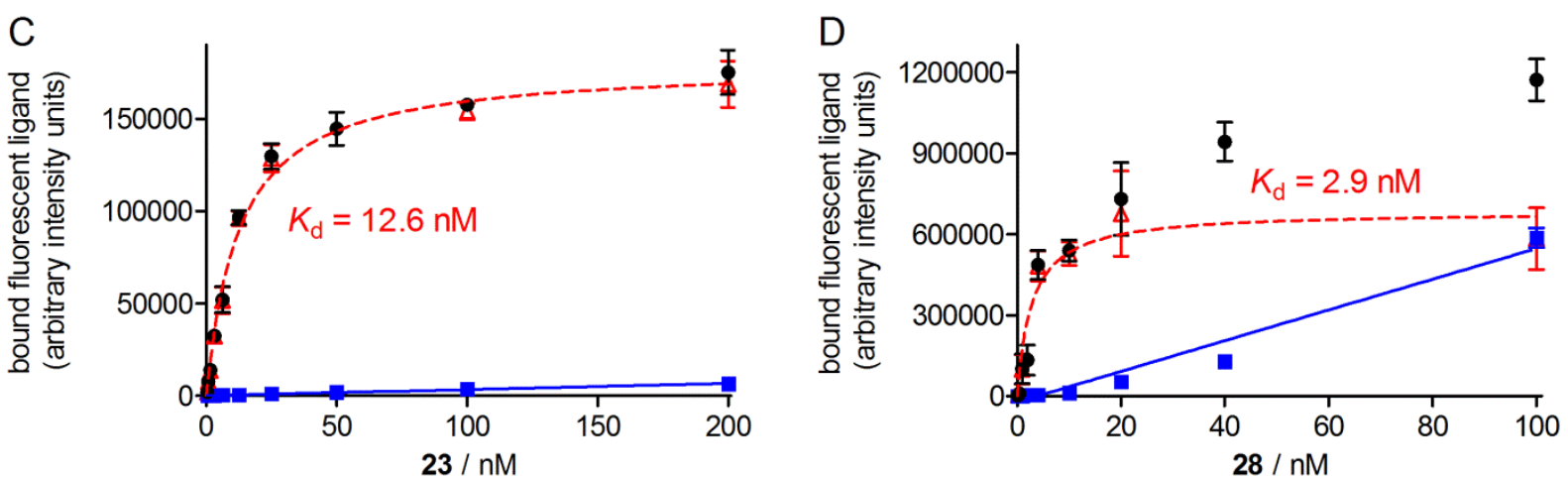

Figure 7. Representative saturation isotherms (specific binding, dashed line) obtained from high-content imaging saturation binding experiments performed with 18 (A), 20 (B), 23 (C) and 28 (D) at intact $\mathrm{CHO}-\mathrm{hM}_{2} \mathrm{R}$ cells. Unspecific binding was determined in the presence of atropine (500-fold excess to 18, 20, 23 or 28). Cells were incubated with the fluorescent ligands at $22{ }^{\circ} \mathrm{C}$ in the dark for $1 \mathrm{~h}$ followed by a wash step and immediate measurement with an IX Ultra Confocal Plate Reader (Molecular Devices). Experiments were performed in triplicate. In the case of total and unspecific binding, data represent mean values \pm SEM. In the case of specific binding, data represent calculated values \pm propagated error.

In order to further support the hypothesis of dualsteric binding of the fluorescent ligands to the $\mathrm{M}_{2} \mathrm{R}$ (concluded, e.g. from dissociation experiments with $\mathbf{2 3}$ in the presence of various allosteric $\mathrm{M}_{2} \mathrm{R}$ modulators; see Figure 5B), saturation binding experiments were performed with 20, 23 and 28 in the presence of the negative allosteric $\mathrm{M}_{2} \mathrm{R}$ modulator 32 (structure see Figure $\mathrm{S} 4$, 
Supporting Information), ${ }^{55-57}$ applied at increasing concentrations (Schild-like analysis, Figure 8). This kind of experiment is equivalent to the Schild analysis used to investigate the inhibiting effect of a receptor antagonist on the response elicited by an agonist, ${ }^{62-64}$ and was applied, for instance, to prove the dualsteric binding mode of $\left[{ }^{3} \mathrm{H}\right] 6$ and $\left[{ }^{3} \mathrm{H}\right] 7$ at the $\mathrm{hM}_{2} \mathrm{R}^{38,39}$ as well as of a fluorescent pirenzepine derivative at the $M_{1} R \cdot{ }^{31}$ In the presence of $\mathbf{3 2}$, the saturation isotherms of both monomeric ligands $(\mathbf{2 0}, \mathbf{2 3})$ and of the dimeric ligand 28 were rightward shifted resulting in linear 'Schild' regressions with a slope not different from unity (Figure 8; Table S1, Supporting Information). These results were further indication of a competitive mechanism between the allosteric $\mathrm{M}_{2} \mathrm{R}$ ligand $\mathbf{3 2}$ and the fluorescent dibenzodiazepinone-type ligands $\mathbf{2 0}$, 23 and 28. 

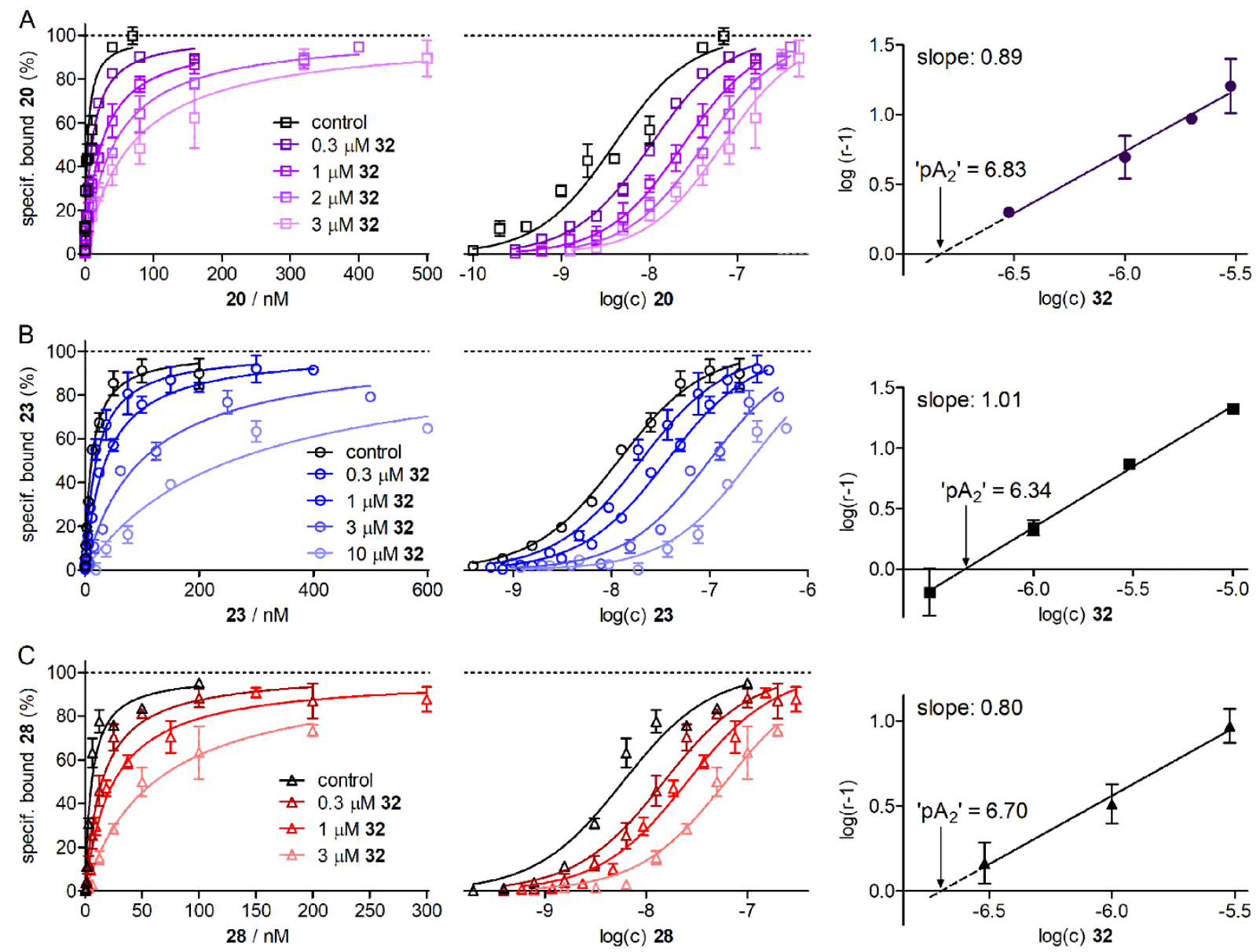

Figure 8. Saturation binding of 20 (A), 23 (B) and 28 (C) at the $\mathrm{hM}_{2} \mathrm{R}$ in the presence of the allosteric $\mathrm{M}_{2} \mathrm{R}$ modulator 32 (for structure see Figure S4, Supporting Information) determined at intact $\mathrm{CHO}-\mathrm{hM}_{2} \mathrm{R}$ cells using high-content imaging. Presented are saturation isotherms of specific fluorescent ligand binding (left, linear scale; middle, semi-logarithmic scale) and 'Schild' regressions (right) resulting from the rightward shifts $\left(\Delta \mathrm{p} K_{\mathrm{d}}\right)$ of the saturation isotherms $\left(\log (\mathrm{r}-1)\right.$ plotted vs. $\log ($ concentration allosteric modulator $)$, where $\left.\mathrm{r}=10^{\Delta \mathrm{p} K \mathrm{~d}}\right)$. Increasing concentrations of $\mathbf{3 2}$ resulted in a rightward shift of the saturation isotherms of the fluorescently labeled dibenzodiazepinone derivatives 20, 23 and 28. In all cases, the slope of the linear "Schild" regression was close to unity (for statistical evaluation see Table S1, Supporting Information), indicating a competitive interaction between the fluorescent ligands and the allosteric modulator 32. Data represent mean values \pm SEM from three independent experiments (performed in triplicate). Note: In case of the logistic (sigmoidal) fits (middle), initial four parameter fitting to allow variation in the Hill factor, did not result in slopes 
significantly different from unity $(\mathrm{P}>0.05)$ except for ' $20+2 \mu \mathrm{M} 32$ ' $($ slope $=0.94 \pm 0.01, \mathrm{P}$ $<0.02$ ) and ' $23+0.3 \mu \mathrm{M} 32$ ' (slope $=1.23 \pm 0.04, \mathrm{P}<0.05$ ). As these slopes were still close to unity, the data were also analyzed using a fixed slope of 1 , which did not affect the respective $\mathrm{p} K_{\mathrm{d}}$ values (deviations $<0.2 \%$ ).

The ' $\mathrm{pA}_{2}$ ' values of $\mathbf{3 2}$ derived from the 'Schild' regressions were in good agreement with a reported ' $\mathrm{pA}_{2}$ ' of $\mathbf{3 2}^{38}$ and with the $\mathrm{p} K_{\mathrm{i}}$ values of $\mathbf{3 2}$ from equilibrium competition binding studies with 20, 23 and 28 (described below; Table S1, Supporting Information). With regard to the fact that $\mathbf{2 0}, \mathbf{2 3}$ and $\mathbf{2 8}$ address the orthosteric binding site of the $\mathrm{M}_{2} \mathrm{R}$ (concluded from experimental data presented in Figures 4 and 7) the results of the Schild-like analyses suggested, as already reported, e.g. for the dibenzodiazepinone-type MR ligands $\mathbf{6}$ and 7,,38,39 a dualsteric binding mode of $\mathbf{2 0}, \mathbf{2 3}$ and $\mathbf{2 8}$ at the $\mathrm{hM}_{2} \mathrm{R}$.

Fluorescence-based competition binding studies. The fluorescent probes 18, 20, 23 and 28 were applied in competition binding studies at $\mathrm{CHO}-\mathrm{hM}_{2} \mathrm{R}$ cells to determine $\mathrm{M}_{2} \mathrm{R}$ affinities of various reported MR ligands, including orthosteric antagonists (NMS, atropine (31)), orthosteric agonists (xanomeline (35), oxotremorine (36)), allosteric modulators (W84 (32), ${ }^{55}$ LY2119620 (33) $)^{58,59}$ ), and dualsteric ligands (6, UR-AP060 (37), ${ }^{38}$ AF-DX $384(\mathbf{3 8})^{65,66}$ ) (for structures see Figure S4, Supporting Information, and Figure 1B). In high-content imaging binding assays, NMS, compounds 6, 31-33 and 35-37 fully competed for specific $\mathrm{hM}_{2} \mathrm{R}$ binding of $\mathbf{2 0 ,} \mathbf{2 3}$ or $\mathbf{2 8}$, indicating a competitive mechanism between the reported MR ligands and $\mathbf{2 0}$, 23 and 28 ( $c f$. Figure S7B-S7D, Supporting Information). As the allosteric $\mathrm{M}_{2} \mathrm{R}$ ligands 32 and 33 were capable of complete displacement of $\mathbf{2 0}, \mathbf{2 3}$ and $\mathbf{2 8}$ at the $\mathrm{hM}_{2} \mathrm{R}$, these results support the hypothesis of a dualsteric binding mode of $\mathbf{2 0}, \mathbf{2 3}$ and $\mathbf{2 8}$ at the $\mathrm{hM}_{2} \mathrm{R}$, and are consistent with the results from the Schild analysis (Figure 8). Flow cytometric competition binding experiments with 20 and the reported MR ligands 6, 31-33, 35 and 38 also resulted throughout 
in complete displacement of $\mathbf{2 0}$ (Figure S7E and S7F, Supporting Information). The reference compound $\mathrm{p} K_{\mathrm{i}}$ values $(\mathrm{NMS}, \mathbf{6}, \mathbf{3 1 - 3 3}, \mathbf{3 5 - 3 8})$ against different fluorescent tracers $(\mathbf{1 8}, \mathbf{2 0}, \mathbf{2 3}$ or 28) were also compared with the $\mathrm{p} K_{\mathrm{i}}$ values obtained from orthosteric radioligand ([$\left.\left.{ }^{3} \mathrm{H}\right] \mathrm{NMS}\right)$ competition binding experiments. Here, the closest correlation between fluorescent and radioligand data was observed when using fluorescent ligand 23 (Table 6). One explanation may be the nearly fully reversible $\mathrm{M}_{2} \mathrm{R}$ binding of $\mathbf{2 3}$, compared to the persistence of a long lasting pseudo-irreversible component identified in $\mathbf{2 0}$ and $\mathbf{2 8}$ dissociation experiments (Figure $5)$.

To discriminate between a competitive and an allosteric interaction of the allosteric $M_{2} R$ modulator 32 and the dibenzodiazepinone-type fluorescent MR ligands, the effect of $\mathbf{3 2}$ on $\mathrm{hM}_{2} \mathrm{R}$ equilibrium binding of 20, applying a high $\mathrm{M}_{2} \mathrm{R}$ occupancy by $\mathbf{2 0}\left(\mathrm{c}=20 \mathrm{nM}, K_{\mathrm{d}}=0.91\right.$ $\mathrm{nM}$, fractional receptor occupancy: 0.96), was determined. In case of a negative allosteric mechanism between $\mathbf{3 2}$ and 20, this type of experiment would result in an elevation of the lower curve plateau (four-parameter logistic fit), and the $\mathrm{pIC}_{50}$ value of $\mathbf{3 2}$ would be unaffected compared to the experiment using a concentration of $\mathbf{2 0}$ close to its $K_{\mathrm{d}}$ value (such a noncompetitive behavior was previously demonstrated, e.g., for $\left[{ }^{3} \mathrm{H}\right] \mathrm{NMS}$ and $\mathbf{3 2}^{38}$ ). However, as shown in Figure S7F (Supporting Information), the lower curve plateau did not increase and the $\mathrm{pIC}_{50}$ of $\mathbf{3 2}$ was rightward shifted by approx. one order of magnitude, being consistent with a competitive mechanism between $\mathbf{2 0}$ and $\mathbf{3 2}$. 
Table 6. $\mathrm{M}_{2} \mathrm{R}$ binding data $\left(\mathrm{p} K_{\mathrm{i}}\right.$ or $\left.\mathrm{pIC}_{50}\right)$ of various orthosteric $(\mathrm{NMS}, \mathbf{3 1}, \mathbf{3 5}, \mathbf{3 6})$, allosteric $(32,33)$ and dualsteric $(6,37,38)$ MR ligands determined by the use of the fluorescent ligands $\mathbf{1 8}, \mathbf{2 0}, \mathbf{2 3}$ or $\mathbf{2 8}$, and with the orthosteric radioligand $\left[{ }^{3} \mathrm{H}\right] \mathrm{NMS}$.

\begin{tabular}{|c|c|c|c|c|c|c|}
\hline \multirow[t]{3}{*}{ compd. } & \multicolumn{6}{|c|}{ labeled ligand used for competition binding studies } \\
\hline & 20 & 18 & 20 & 23 & 28 & {$\left[{ }^{3} \mathrm{H}\right] \mathrm{NMS}$} \\
\hline & $\begin{array}{c}\mathrm{p} K_{\mathrm{i}} \pm \mathrm{SEM}^{a} \\
\text { slope } \pm S E M^{b} \\
\text { (flow cytometry) }\end{array}$ & & $\begin{array}{r}\mathrm{p} K_{\mathrm{i}} \pm \\
\text { slope } \pm \\
\text { (high-conte }\end{array}$ & $\begin{array}{l}\mathrm{SEM}^{c} \\
S E M^{b} \\
\text { nt imaging) }\end{array}$ & & $\begin{array}{l}\mathrm{p} K_{\mathrm{i}}^{*} \text { or } \mathrm{pIC}_{50} * * \\
\text { (radiochemical) }\end{array}$ \\
\hline NMS & - & $\begin{array}{l}8.95 \pm 0.13 \\
-1.7 \pm 0.2^{d}\end{array}$ & $\begin{array}{c}8.93 \pm 0.14 \\
-1.6 \pm 0.5\end{array}$ & $\begin{array}{l}9.86 \pm 0.17 \\
-1.1 \pm 0.2\end{array}$ & $\begin{array}{c}9.23 \pm 0.08 \\
-0.83 \pm 0.01^{d}\end{array}$ & $10.01 \pm 0.08^{* e}$ \\
\hline 6 & $\begin{array}{c}8.70 \pm 0.05 \\
-0.96 \pm 0.33\end{array}$ & - & - & $\begin{array}{l}9.00 \pm 0.28 \\
-1.0 \pm 0.04\end{array}$ & $\begin{array}{l}8.39 \pm 0.17 \\
-1.2 \pm 0.1\end{array}$ & $9.12 * f$ \\
\hline $\begin{array}{c}\mathbf{3 1} \\
\text { (atropine) }\end{array}$ & $\begin{array}{c}8.60 \pm 0.21 \\
-0.78 \pm 0.16\end{array}$ & $\begin{array}{c}7.73 \pm 0.07 \\
-0.89 \pm 0.37\end{array}$ & $\begin{array}{l}8.31 \pm 0.08 \\
-1.2 \pm 0.2\end{array}$ & $\begin{array}{c}8.50 \pm 0.11 \\
-0.79 \pm 0.05\end{array}$ & $\begin{array}{c}8.15 \pm 0.07 \\
-1.1 \pm 0.1\end{array}$ & $9.04 \pm 0.08^{* e}$ \\
\hline $\begin{array}{c}32 \\
(\mathrm{~W} 84)\end{array}$ & $\begin{array}{c}6.39 \pm 0.09 \\
-0.78 \pm 0.05\end{array}$ & - & $\begin{array}{c}5.85 \pm 0.08 \\
-0.88 \pm 0.11\end{array}$ & $\begin{array}{l}6.19 \pm 0.16 \\
-1.1 \pm 0.3\end{array}$ & $\begin{array}{l}6.07 \pm 0.08 \\
-1.2 \pm 0.3\end{array}$ & $6.32 * * f$ \\
\hline $\begin{array}{c}33 \\
\text { (LY2119620) }\end{array}$ & $\begin{array}{l}5.19 \pm 0.07 \\
-1.5 \pm 0.1\end{array}$ & - & $\begin{array}{c}5.45 \pm 0.21 \\
-1.9 \pm 0.3\end{array}$ & $\begin{array}{l}5.04 \pm 0.06 \\
-1.8 \pm 0.1^{d}\end{array}$ & $\begin{array}{l}5.03 \pm 0.20 \\
-1.0 \pm 0.2\end{array}$ & $<4.5^{* * f}$ \\
\hline $\begin{array}{c}35 \\
\text { (xanomeline) }\end{array}$ & $\begin{array}{l}6.67 \pm 0.02 \\
-1.1 \pm 0.2\end{array}$ & $\begin{array}{l}6.14 \pm 0.01 \\
-1.4 \pm 0.3\end{array}$ & $\begin{array}{l}6.42 \pm 0.03 \\
-1.6 \pm 0.4\end{array}$ & $\begin{array}{l}6.49 \pm 0.15 \\
-1.1 \pm 0.1\end{array}$ & $\begin{array}{l}6.56 \pm 0.14 \\
-1.0 \pm 0.2\end{array}$ & $6.70 \pm 0.16^{* e}$ \\
\hline $\begin{array}{c}\mathbf{3 6} \\
\text { (oxotremorine) }\end{array}$ & - & - & $\begin{array}{l}6.07 \pm 0.19 \\
-1.1 \pm 0.5\end{array}$ & $\begin{array}{c}5.99 \pm 0.03 \\
-0.86 \pm 0.24\end{array}$ & $\begin{array}{l}5.75 \pm 0.04 \\
-1.0 \pm 0.3\end{array}$ & $7.04 \pm 0.12 * e$ \\
\hline $\begin{array}{c}37 \\
\text { (UR-AP060) }\end{array}$ & - & - & - & $\begin{array}{l}9.45 \pm 0.13 \\
-1.1 \pm 0.04\end{array}$ & $\begin{array}{l}9.28 \pm 0.18 \\
-1.5 \pm 0.4\end{array}$ & $9.39 * f$ \\
\hline $\begin{array}{c}38 \\
(\text { AF-DX 384) }\end{array}$ & $\begin{array}{c}8.31 \pm 0.18 \\
-0.75 \pm 0.12\end{array}$ & - & - & - & - & $8.71 \pm 0.04^{* e}$ \\
\hline
\end{tabular}

${ }^{a}$ Determined by flow cytometric competition binding experiments with $\mathbf{2 0}(1 \mathrm{nM})$ at live $\mathrm{CHO}_{-} \mathrm{hM}_{2} \mathrm{R}$ cells; mean values \pm SEM from at least two independent experiments (performed in duplicate). ${ }^{b}$ Curve slope of the fourparameter logistic fit. ${ }^{c}$ Determined by high-content imaging competition binding with $18(10 \mathrm{nM}), 20(10 \mathrm{nM}), 23$ $(10 \mathrm{nM})$ or $28(10 \mathrm{nM})$ at intact $\mathrm{CHO}-\mathrm{hM}_{2} \mathrm{R}$ cells; mean values $\pm \mathrm{SEM}$ from at least two independent experiments (performed in duplicate). ${ }^{d}$ Slope different from unity $(\mathrm{P}<0.05) .{ }^{e}$ Determined by competition binding studies with $\left[{ }^{3} \mathrm{H}\right] \mathrm{NMS}(\mathrm{c}=0.2 \mathrm{nM})$ at live $\mathrm{CHO}-\mathrm{hM}_{2} \mathrm{R}$ cells; mean values \pm SEM from at least two independent experiments (performed in triplicate). ${ }^{f}$ Pegoli et al, ${ }^{38} \mathrm{pIC}_{50}$ values were not converted to $\mathrm{p} K_{\mathrm{i}}$ values as 32 and $\mathbf{3 3}$ inhibit $\left[{ }^{3} \mathrm{H}\right] \mathrm{NMS}$ binding in a non-competitive manner.

Molecular dynamics (MD) simulations. To model the interactions between the fluorescent dibenzodiazepinone derivatives and the $\mathrm{M}_{2} \mathrm{R}$, MD simulations $(5 \mu \mathrm{s})$ of the human $\mathrm{M}_{2} \mathrm{R}$ bound to the fluorescent ligands $\mathbf{2 3}$ or $\mathbf{2 8}$ were performed by analogy with a MD simulation described for $6 .^{38}$ It should be noted that such short scale MD simulations, starting from a docking pose and requiring numerous simplifications, can only give a vague idea of the binding mode, but 
are by far incapable of describing the whole ligand binding process. According to the simulation data, both ligands exhibited comparable orthosteric receptor interactions, which were persistent over the whole simulation timeframe (Figure 9A and 9B, Figure S10B, Supporting Information). The allosteric vestibule ('common' allosteric site) of the $\mathrm{hM}_{2} \mathrm{R}$ was primarily occupied by the linker moieties in $\mathbf{2 3}$ and $\mathbf{2 8}$ (Figure 9A and 9B), but not by the fluorophores. This supports the competitive pharmacological interaction between the fluorescent ligands and the allosteric modulator 32 at the $\mathrm{hM}_{2} \mathrm{R}$ ( $c f$. Figures 5B and 8, and Figure S7F, Supporting Information). The monomeric ligand $\mathbf{2 3}$ showed no persistent hydrogen bonds except for those in the orthosteric binding site, but a cation- $\pi$ interaction with $\mathrm{W} 422^{7.35}$, a key residue involved in binding of allosteric MR modulators, ${ }^{67}$ was evident as "allosteric contact" (Figure 9A, Figure S10B, Supporting Information). In case of the homodimeric fluorescent ligand $\mathbf{2 8}$, hydrogen bonds to $\mathrm{T} 84^{2.65}, \mathrm{D} 173^{\mathrm{ECL} 2}$ and $\mathrm{E} 175^{\mathrm{ECL} 2}$, located in the allosteric vestibule and in ECL2, respectively, were identified as allosteric interactions (Figure 9B, Figure S10B, Supporting Information). Whereas the fluorophore and a part of the linker of $\mathbf{2 3}$ showed high flexibility over the whole time period of the simulation (Figure 9C), the non-orthosterically bound part of the dimeric ligand $\mathbf{2 8}$ proved to be considerably less flexible (Figure 9D). This was also evident from an RMSD analysis of $\mathbf{2 3}$ and $\mathbf{2 8}$ (Figure S11, Supporting Information), although one has to keep in mind that the RMSD analysis considers the entire ligand structure. As reported previously for a $\mathrm{MD}$ simulation of the $\mathrm{hM}_{2} \mathrm{R}$ bound to compound $\mathbf{6}$, the highly conserved D103 ${ }^{3.32}$, which typically interacts with MR agonists, ${ }^{68}$ formed a cluster with S76 2.57 , W99 ${ }^{3.28}$, Y426 7.39 and Y430 7.43 (Figure S10A, Supporting Information) instead of interacting with the antagonists 23 and 28 . This was also reported for crystal structures of the $M_{1} R$ and $M_{4} R$ in complex with an antagonist. ${ }^{69}$ 


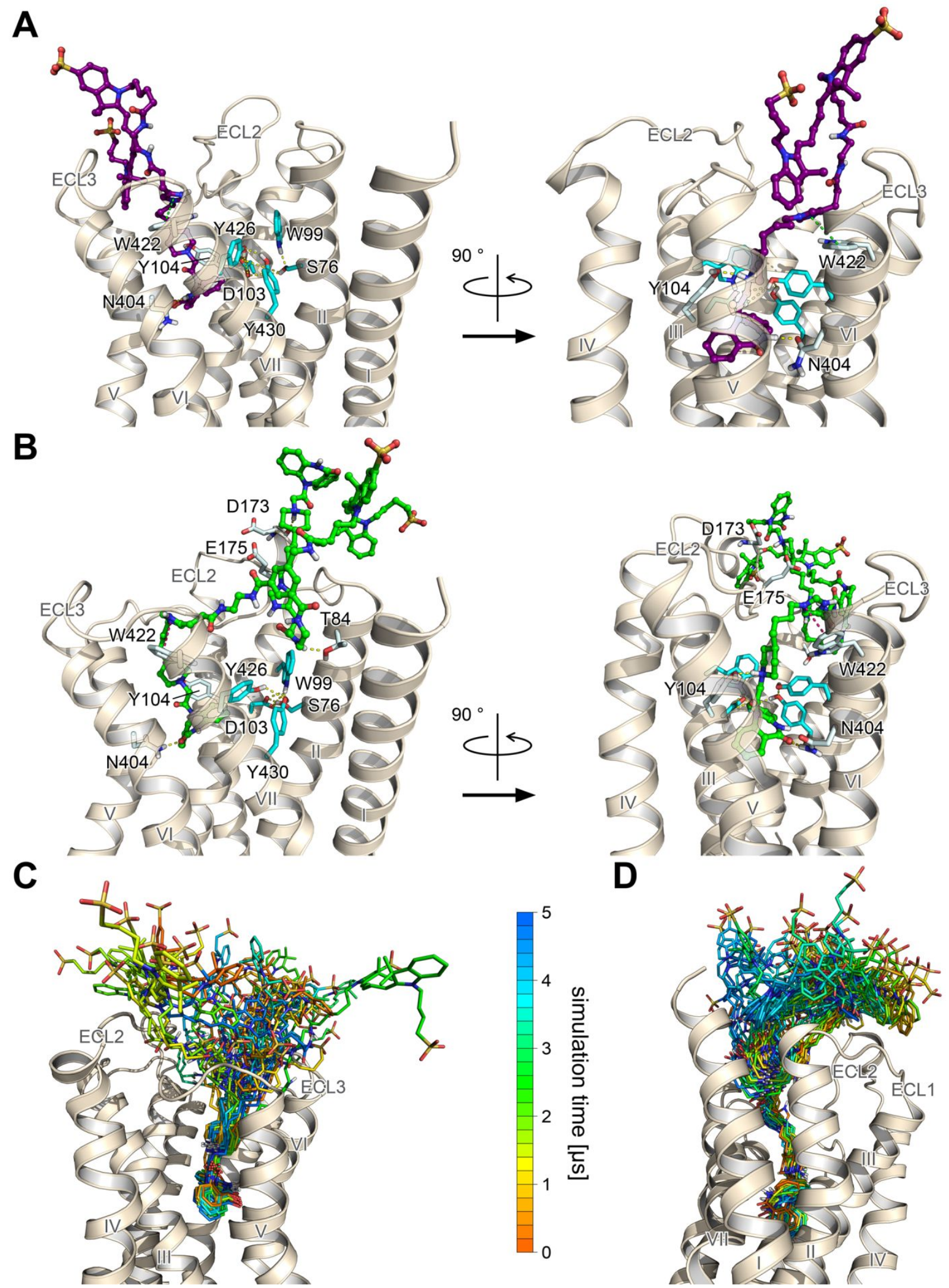

Figure 9. Molecular dynamics simulations ( $5 \mu \mathrm{s})$ of the human $\mathrm{M}_{2} \mathrm{R}$ (inactive state, PDB code $3 \mathrm{UON}^{70}$ ) bound to the fluorescent dibenzodiazepinone derivatives 23 (A, C) or 28 (B, D). (A) Cluster 0 binding pose of $\mathbf{2 3}$ (shown in purple). (B) Cluster 0 binding pose of $\mathbf{2 8}$ (shown in 
green). In $\mathrm{A}$ and $\mathrm{B}$, carbon atoms of amino acids constituting the $\mathrm{D} 103^{3.32} / \mathrm{S} 76^{2.57} / \mathrm{W} 99^{3.28} / \mathrm{Y} 426^{7.39} / \mathrm{Y}_{430^{7.43}}$ cluster are highlighted in cyan. H-bonds between ligand and receptor (yellow dashed lines) were identified for Y104 $4^{3.33}$ (o.) and N404 ${ }^{6.52}$ (o.) (A), as well as for $\mathrm{T} 84^{2.65}$ (a.), $\mathrm{Y} 104^{3.33}$ (o.), $\mathrm{D} 173^{\mathrm{ECL} 2}$ (a.), $\mathrm{E} 175^{\mathrm{ECL} 2}$ (a.) and $\mathrm{N} 404^{6.25}$ (o.) (B). In A, $\pi-\pi$-stacking (a.) between ligand and receptor is highlighted as green dashed line, and in B, the cation $-\pi$-interaction (a.) between ligand and receptor is highlighted as pink dashed line. (C, D) Time course of the $5 \mu$ s MD simulations of the $\mathrm{hM}_{2} \mathrm{R}$ bound to 23 (C) or 28 (D) showing superimposed snap shots collected every 200 ns. o. $=$ orthosteric, a. $=$ allosteric.

\section{Conclusion}

The study presents a series of fluorescence-labeled dibenzodiazepinone-type, $\mathrm{M}_{2} \mathrm{R}$ subtypepreferring $\mathrm{MR}$ antagonists, comprising compounds with high $\mathrm{M}_{2} \mathrm{R}$ affinity $\left(\mathrm{p} K_{\mathrm{i}}>8.5\right)$. Saturation binding and dissociation experiments at the $\mathrm{M}_{2} \mathrm{R}$ in the absence and in the presence of allosteric $\mathrm{M}_{2} \mathrm{R}$ ligands suggested a dualsteric binding mode at the $\mathrm{M}_{2} \mathrm{R}$. The application of the presented type of fluorescent probes in flow cytometric and high-content imaging binding assays as well to confocal microscopy, revealed their suitability as molecular tools to study $\mathrm{M}_{2} \mathrm{R}$ expression in cells and to determine $\mathrm{M}_{2} \mathrm{R}$ binding affinities of (non-labeled) orthosteric and allosteric $\mathrm{M}_{2} \mathrm{R}$ ligands. As the presented fluorescent $\mathrm{M}_{2} \mathrm{R}$ ligands lack selectivity towards the $\mathrm{M}_{1}$ and $\mathrm{M}_{4}$ receptor, this compound class might be useful for the design and preparation of fluorescent probes with high $\mathrm{M}_{1} \mathrm{R}, \mathrm{M}_{2} \mathrm{R}$ or $\mathrm{M}_{4} \mathrm{R}$ affinity, using fluorophores with properties compatible with fluorescence based techniques such as (time-resolved-)FRET measurements, fluorescence correlation spectroscopy and fluorescence anisotropy based methods. On the other hand, the combination of fluorescence labeling with a recently reported approach to increase $M_{2} R$ selectivity of dibenzodiazepinone-type $M R$ ligands ${ }^{71}$ might lead to $M_{2} R$ selective fluorescent probes. 


\section{Experimental section}

General experimental conditions. Standard chemicals and solvents were purchased from commercial suppliers and were used without further purification. Acetonitrile for HPLC (gradient grade) was obtained from Merck (Darmstadt, Germany) or Sigma-Aldrich (Taufkirchen, Germany). CCh, NMS, atropine (31), W84 (32) and Hoechst 33342 (H33342) were purchased from Sigma-Aldrich. Oxotremorine sesquifumarate (36) was from MP Biomedicals (Eschwege, Germany) and LY2119620 (33) was purchased from Absource Diagnostic (Munich, Germany). AF-DX 384 (38) was from Abcam (Cambridge, UK). The indolinium-type cyanine dye succinimidyl esters 11, 13 and 19 were obtained from FEW Chemicals (Bitterfeld-Wolfen, Germany). $\left[{ }^{3} \mathrm{H}\right] \mathrm{NMS}$ (specific activity $=80 \mathrm{Ci} / \mathrm{mmol}$ ) was purchased from American Radiolabeled Chemicals Inc. (St. Louis, MO) via Hartman Analytics (Braunschweig, Germany). The syntheses of $\mathbf{6},{ }^{38} \mathbf{8},{ }^{42} \mathbf{1 5},{ }^{39} \mathbf{2 1},{ }^{42} \mathbf{2 5},{ }^{27} \mathbf{2 6},{ }^{38} \mathbf{2 9}{ }^{39}$ and $\mathbf{3 7}{ }^{38}$ were described elsewhere. Xanomeline $(\mathbf{3 5})^{72}$ and the pyrylium dye $9^{73}$ were prepared according to described procedures. Millipore water was used throughout for the preparation of buffers and HPLC eluents. Polypropylene reaction vessels (1.5 or $2 \mathrm{~mL}$ ) with screw cap (Süd-Laborbedarf, Gauting, Germany) were used for the synthesis of the fluorescent ligands $(\mathbf{1 0}, \mathbf{1 2}, \mathbf{1 4}, \mathbf{1 6}-\mathbf{1 8}$, 20, 22, 23, 27, 28 and 30) and for the preparation and storage of stock solutions. NMR spectra were recorded on a Bruker Avance III HD 600 equipped with a cryogenic probe $(14.1 \mathrm{~T} ; 1 \mathrm{H}$, $600 \mathrm{MHz}$ (Bruker, Karlsruhe, Germany). Abbreviations for the multiplicities of the signals are $\mathrm{s}$ (singlet), d (doublet), $\mathrm{t}$ (triplet), $\mathrm{tt}$ (triplet of triplet), m (multiplet), and brs (broad-singlet). High-resolution mass spectrometry (HRMS) analysis was performed with an Agilent 6540 UHD Accurate-Mass Q-TOF LC/MS system (Agilent Technologies, Santa Clara, CA) using an ESI source. Preparative HPLC was performed with a system from Knauer (Berlin, Germany) consisting of two K-1800 pumps and a K-2001 detector. A Kinetex-XB C18 $(5 \mu \mathrm{m}, 250 \times 21$ $\mathrm{mm}$; Phenomenex, Aschaffenburg, Germany) was used as stationary phase at a flow rate of 15, 18 or $20 \mathrm{~mL} / \mathrm{min}$. Mixtures of acetonitrile and $0.1 \%$ or $0.2 \%$ aq TFA were used as mobile phase. 
The detection wavelength was set to $220 \mathrm{~nm}$ throughout. The solvent of the collected fractions was removed by lyophilization using an Alpha 2-4 LD apparatus (Martin Christ, Osterode am Harz, Germany) equipped with a RZ 6 rotary vane vacuum pump (Vacuubrand, Wertheim, Germany). For compounds 10, 12, 14, 16-18 and 20 analytical HPLC analysis (purity control) was performed on a system from Merck-Hitachi (Hitachi, Düsseldorf, Germany) composed of a L-6200-A pump, an AS-2000A autosampler, a L-4000A UV detector and a D-6000 interface. A Kinetex-XB C18, $5 \mu \mathrm{m}, 250 \times 4.6 \mathrm{~mm}$ (Phenomenex) was used as stationary phase at a flow rate of $0.8 \mathrm{~mL} / \mathrm{min}$. Mixtures of $0.1 \%$ aq TFA (A) and acetonitrile (B) were used as mobile phase (degassed by helium purging). The following linear gradient was applied: 0-30 min: A/B 95:5-15:85, 30-32 min: 15:85-5:95, 32-40 min: 5:95. The oven temperature was set to $25^{\circ} \mathrm{C}$ and detection was performed at $220 \mathrm{~nm}$. Analytical HPLC analysis of compounds 20 (chemical stability), 22, 23, 27, 28 and $\mathbf{3 0}$ was performed with a system from Agilent Technologies composed of a 1290 Infinity binary pump equipped with a degasser, a 1290 Infinity autosampler, a 1290 Infinity thermostated column compartment, a 1260 Infinity diode array detector, and a 1260 Infinity fluorescence detector. A Kinetex-XB C18, $2.6 \mu \mathrm{m}, 100 \times 3 \mathrm{~mm}$ (Phenomenex) served as stationary phase at a flow rate of $0.5 \mathrm{~mL} / \mathrm{min}$. Mixtures of $0.04 \%$ aq TFA (A) and acetonitrile (B) were used as mobile phase. The following linear gradients were applied: compounds 22, 23, 27, 28 and $\mathbf{3 0}$ (purity): 0-20 min: A/B 85:15-50:50, 20-22 min: 50:50-5:95, 22-28 min: 5:95; compounds 20 and 30 (chemical stabilities): 0-20 min: A/B 90:1068:32, 20-22 min: 68:32-5:95, 22-26 min: 5:95. The oven temperature was set to $25^{\circ} \mathrm{C}$ and detection was performed at $220 \mathrm{~nm}$. Stock solutions $(1,5$ or $10 \mathrm{mM})$ of fluorescent ligands were prepared in DMSO and were stored at $-78^{\circ} \mathrm{C}$. Sigmacote (Sigma) was used for "siliconization" (coating) of glass and polypropylene reaction vessels used for the investigation of the chemical stabilities of 20, 23, 28 and $\mathbf{3 0}$. 
Compound Characterization. All target compounds (fluorescent ligands 10, 12, 14, 16-18, 20, 22, 23, 27, 28 and 30) were characterized by HRMS and RP-HPLC analysis. Additionally, compounds 10, 12, 14, 17, 18, 20, 22, 23, 27, 28 and 30 were characterized by ${ }^{1} \mathrm{H}-\mathrm{NMR}$ (spectra shown in the Supporting Information). The HPLC purity of all fluorescent ligands amounted to $\geq 96 \%$ (220 nm) (chromatograms shown in the Supporting Information).

Screening for pan-assay interference compounds (PAINS). Screening of all target compounds for PAINS via the public tool http://zinc15.docking.org/patterns/home, ${ }^{74}$ yielded no hits except for compounds $\mathbf{1 0}$ and $\mathbf{1 6}$. In case of $\mathbf{1 0}$ and $\mathbf{1 6}$, the $N, N$-dimethylaniline partial structure was identified as PAIN. The identities of $\mathbf{1 0}$ and $\mathbf{1 6}$ were proven by HRMS (in case of $\mathbf{1 0}$ additionally by $\left.{ }^{1} \mathrm{H}-\mathrm{NMR}\right)$ and both compounds exhibited a purity of $98 \%$. Moreover, there are no reports on the $N, N$-dimethylaniline scaffold to exhibit high MR affinity as determined for $\mathbf{1 0}$ and $\mathbf{1 6}$. Therefore, an interference in the radioligand competition binding assays by an impurity containing a $N, N$-dimethylaniline scaffold can be excluded.

Chemistry: experimental protocols and analytical data of compounds 10, 12, 14, 16-18, 20, 22, 23, 27, 28 and 30

4-((1E,3E)-4-(4-(Dimethylamino)phenyl)buta-1,3-dien-1-yl)-2,6-dimethyl-1-(4-(1-(2-oxo2-(11-oxo-10,11-dihydro-5H-dibenzo $[b, e][1,4]$ diazepin-5-yl)ethyl)piperidin-4yl)butyl)pyridin-1-ium hydrotrifluoroacetate trifluoroacetate (10). The reaction was carried out in a $1.5-\mathrm{mL}$ polypropylene reaction vessel equipped with a micro stir bar. Amine 8 (2.0 mg, $4.92 \mu \mathrm{mol})$ and triethylamine $(5.0 \mathrm{mg}, 6.8 \mu \mathrm{L}, 49 \mu \mathrm{mol})$ were dissolved in anhydrous DMF $(300 \mu \mathrm{L})$ followed by the addition of $9(5.4 \mathrm{mg}, 15 \mu \mathrm{mol})$ in anhydrous DMF $(120 \mu \mathrm{L})$ and stirring at $\mathrm{rt}$ in the dark for $2 \mathrm{~h} .10 \%$ aq TFA (corresponding to ca. $50 \mu \mathrm{mol}$ of TFA) was added. Purification of the product by preparative HPLC (flow rate: $15 \mathrm{~mL} / \mathrm{min}$; gradient: 0-30 
min: $0.1 \%$ aq TFA/acetonitrile 95:5-38:62, $\left.t_{\mathrm{R}}=17 \mathrm{~min}\right)$ afforded $\mathbf{1 0}$ as a red solid $(0.91 \mathrm{mg}$, 21\%). RP-HPLC (220 nm): 98\% ( $\left.t_{\mathrm{R}}=19.4 \mathrm{~min}, k=5.8\right) .{ }^{1} \mathrm{H}-\mathrm{NMR}\left(600 \mathrm{MHz}, \mathrm{MeOH}-d_{4}\right)($ ratio of observed configurational isomers: ca 1.5:1): $\delta(\mathrm{ppm}) 1.38-1.62(\mathrm{~m}, 7 \mathrm{H}), 1.79-1.86(\mathrm{~m}, 2 \mathrm{H})$, 1.91-2.04 (m, 2H), $2.78(\mathrm{~s}, 6 \mathrm{H}), 2.89-2.98(\mathrm{~m}, 1 \mathrm{H}), 2.99-3.10(\mathrm{~m}, 7 \mathrm{H}), 3.42-3.51(\mathrm{~m}, 1 \mathrm{H}), 3.69-$ $3.83(\mathrm{~m}, 2 \mathrm{H}), 4.32-4.38(\mathrm{~m}, 2 \mathrm{H}), 4.40(\mathrm{~d}, J 17 \mathrm{~Hz}, 0.6 \mathrm{H}), 4.43(\mathrm{~d}, J 17 \mathrm{~Hz}, 0.4 \mathrm{H}), 6.57$ (d, $J 16$ $\mathrm{Hz}, 1 \mathrm{H}), 6.74-6.78(\mathrm{~m}, 2 \mathrm{H}), 6.91-7.02(\mathrm{~m}, 2 \mathrm{H}), 7.24-7.36(\mathrm{~m}, 2 \mathrm{H}), 7.36-7.41(\mathrm{~m}, 0.4 \mathrm{H})$, 7.417.46 (m, 2H), 7.46-7.55 (m, 2.2H), 7.59-7.73 (m, 5H), 7.73-7.78 (m, 0.4H), 7.88-7.93 (m, 0.6H), 7.95-7.99 (m, 0.4H). HRMS (ESI): $m / z[M]^{+}$calcd. for $\left[\mathrm{C}_{43} \mathrm{H}_{50} \mathrm{~N}_{5} \mathrm{O}_{2}\right]^{+}$668.3959, found: 668.3963. $\mathrm{C}_{43} \mathrm{H}_{50} \mathrm{~N}_{5} \mathrm{O}_{2}{ }^{+} \cdot \mathrm{C}_{4} \mathrm{HF}_{6} \mathrm{O}_{4}^{-}(668.91+227.04)$.

\section{2-((1E,3E)-5-((E)-3,3-Dimethyl-1-(6-oxo-6-((4-(1-(2-oxo-2-(11-oxo-10,11-dihydro-}

\section{Hdibenzo[b,e][1,4]diazepin-5-yl)ethyl)piperidin-4-yl)butyl)amino)hexyl)indolin-2-}

\section{ylidene)penta-1,3-dien-1-yl)-1,3,3-trimethyl-3 $H$-indol-1-ium}

hydrotrifluoroacetate

trifluoroacetate (12). Compound 12 was prepared from amine $8(2.2 \mathrm{mg}, 5.4 \mu \mathrm{mol})$ and 11 (2.4 mg, $3.6 \mu \mathrm{mol})$ according to the procedure for the synthesis of 10, but DIPEA ( $4.7 \mathrm{mg}, 6.3$ $\mu \mathrm{L}, 36 \mu \mathrm{mol}$ ) was used instead of triethylamine. Purification by preparative HPLC (flow rate: $15 \mathrm{~mL} / \mathrm{min}$; gradient: 0-30 min: $\mathrm{MeCN} / 0.1 \%$ aq TFA/acetonitrile 95:5-10:90, $t_{\mathrm{R}}=14 \mathrm{~min}$ ) afforded compound 12 as a dark blue solid (1.62 mg, 40\%). RP-HPLC (220 nm): 97\% $\left(t_{\mathrm{R}}=\right.$ $25.9 \mathrm{~min}, k=8.0) .{ }^{1} \mathrm{H}-\mathrm{NMR}\left(600 \mathrm{MHz}, \mathrm{MeOH}-d_{4}\right)$ (ratio of observed configurational isomers: ca 1.5:1): $\delta(\mathrm{ppm}) 1.27-1.35(\mathrm{~m}, 4 \mathrm{H}), 1.39-1.53(\mathrm{~m}, 7 \mathrm{H}), 1.64-1.70(\mathrm{~m}, 2 \mathrm{H}), 1.712(\mathrm{~s}, 6 \mathrm{H})$, $1.715(\mathrm{~s}, 6 \mathrm{H}), 1.77-1.85(\mathrm{~m}, 2 \mathrm{H}), 1.85-1.97(\mathrm{~m}, 2 \mathrm{H}), 2.17(\mathrm{t}, J 7.4 \mathrm{~Hz}, 2 \mathrm{H}), 2.85-2.94(\mathrm{~m}, 1 \mathrm{H})$, 2.98-3.05 (m, 1H), $3.11(\mathrm{t}, J 7.2 \mathrm{~Hz}, 2 \mathrm{H}), 3.39-3.46\left(\mathrm{~m}, 1 \mathrm{H}\right.$ (interfering with the ${ }^{13} \mathrm{C}$ satellite of the solvent residual signal)), $3.61(\mathrm{~s}, 3 \mathrm{H}), 3.67-3.80(\mathrm{~m}, 2 \mathrm{H}), 4.08(\mathrm{t}, J 7.4 \mathrm{~Hz}, 2 \mathrm{H}), 4.37$ (d, $J$ $17 \mathrm{~Hz}, 0.6 \mathrm{H}), 4.41$ (d, $J 17 \mathrm{~Hz}, 0.4 \mathrm{H}), 6.26$ (d, J $14 \mathrm{~Hz}, 2 \mathrm{H}), 6.60$ (t, $J 12 \mathrm{~Hz}, 1 \mathrm{H}), 7.23-7.35$ $(\mathrm{m}, 6 \mathrm{H}), 7.36-7.43(\mathrm{~m}, 2.4 \mathrm{H}), 7.45-7.54(\mathrm{~m}, 4.2 \mathrm{H}), 7.59-7.65(\mathrm{~m}, 1.4 \mathrm{H}), 7.66-7.70(\mathrm{~m}, 0.6 \mathrm{H})$ 7.72-7.76 (m, 0.4H), 7.88-7.92 (m, 0.6H), 7.95-7.88 (m, 0.4H), 8.19-8.27 (m, 2H). HRMS 
(ESI): $m / z[\mathrm{M}]^{+}$calcd. for $\left[\mathrm{C}_{56} \mathrm{H}_{67} \mathrm{~N}_{6} \mathrm{O}_{3}\right]^{+}$871.5269, found: 871.5265. $\mathrm{C}_{56} \mathrm{H}_{67} \mathrm{~N}_{6} \mathrm{O}_{3}{ }^{+} \cdot \mathrm{C}_{4} \mathrm{HF}_{6} \mathrm{O}_{4}{ }^{-}$ $(872.19+227.04)$.

\section{4-(2-((1E,3E)-5-((E)-3,3-Dimethyl-1-(6-0xo-6-((4-(1-(2-0xo-2-(11-0xo-10,11-dihydro-} 5Hdibenzo[b,e][1,4]diazepin-5-yl)ethyl)piperidin-4-yl)butyl)amino)hexyl)indolin-2ylidene)penta-1,3-dien-1-yl)-3,3-dimethyl-3H-indol-1-ium-1-yl)butane-1-sulfonate hydrotrifluoroacetate (14). Compound 14 was prepared from amine 8 (1.9 mg, $4.7 \mu \mathrm{mol})$ and $13(2.2 \mathrm{mg}, 3.1 \mu \mathrm{mol})$ according to the procedure for the synthesis of 10, but DIPEA (4.05 mg, $5.5 \mu \mathrm{L}, 31 \mu \mathrm{mol})$ was used instead of triethylamine. Purification by preparative HPLC (conditions as used for $\mathbf{1 2}, t_{\mathrm{R}}=15 \mathrm{~min}$ ) afforded compound $\mathbf{1 4}$ as a dark blue solid (1.43 $\mathrm{mg}$, 37\%). RP-HPLC (220 nm): 96\% $\left(t_{\mathrm{R}}=24.2 \mathrm{~min}, k=7.4\right) .{ }^{1} \mathrm{H}-\mathrm{NMR}\left(600 \mathrm{MHz}, \mathrm{MeOH}-d_{4}\right)($ ratio of observed configurational isomers: ca 1.5:1): $\delta(\mathrm{ppm}) 1.28-1.36(\mathrm{~m}, 4 \mathrm{H}), 1.41-1.55(\mathrm{~m}, 7 \mathrm{H})$, 1.63-1.76 (m, 14H), 1.77-1.89 (m, 3H), 1.90-2.01 (m, 5H), $2.18(\mathrm{t}, J 7.4 \mathrm{~Hz}, 2 \mathrm{H}), 2.85-2.96(\mathrm{~m}$, $3 \mathrm{H}), 3.00-3.08(\mathrm{~m}, 1 \mathrm{H}), 3.10-3.16(\mathrm{~m}, 2 \mathrm{H}), 3.39-3.47\left(\mathrm{~m}, 1 \mathrm{H}\right.$ (interfering with the ${ }^{13} \mathrm{C}$ satellite of the solvent residual signal)), 3.67-3.79 (m, 2H), 4.03-4.16 (m, 4H), 4.37 (d, J $17 \mathrm{~Hz}, 0.6 \mathrm{H})$, $4.43(\mathrm{~d}, J 17 \mathrm{~Hz}, 0.4 \mathrm{H}), 6.23-6.28(\mathrm{~m}, 1 \mathrm{H}), 6.31-6.37$ (m, 1H), 6.59-6.67 (m, 1H), 7.22-7.29 (m, 3.6H), 7.29-7.43 (m, 4.6H), 7.43-7.55 (m, 4.4H), 7.59-7.68 (m, 2H), 7.71-7.76 (m, 0.4H), 7.86-7.90 (m, 0.6H), 7.93-7.97 (m, 0.4H), 8.17-8.26 (m, 2H). HRMS (ESI): $m / z[\mathrm{M}+\mathrm{H}]^{+}$calcd. for $\left[\mathrm{C}_{59} \mathrm{H}_{73} \mathrm{~N}_{6} \mathrm{O}_{6} \mathrm{~S}\right]^{+}$993.5307, found: 993.5317. $\mathrm{C}_{59} \mathrm{H}_{72} \mathrm{~N}_{6} \mathrm{O}_{6} \mathrm{~S} \cdot \mathrm{C}_{2} \mathrm{HF}_{3} \mathrm{O}_{2}(993.32+114.02)$.

\section{4-((1E,3E)-4-(4-(Dimethylamino)phenyl)buta-1,3-dien-1-yl)-2,6-dimethyl-1-(2-(4-(4-(1-} (2-oxo-2-(11-oxo-10,11-dihydro-5H-dibenzo[b,e][1,4]diazepin-5-yl)ethyl)piperidin-4yl)butyl)piperazin-1-yl)ethyl)pyridin-1-ium tris(hydrotrifluoroacetate) trifluoroacetate (16). Compound 16 was prepared from amine $15(3.0 \mathrm{mg}, 3.1 \mu \mathrm{mol})$ and 9 (3.6 mg, $9.9 \mu \mathrm{mol})$ according to the procedure for the synthesis of $\mathbf{1 0}$. Triethylamine: $5.36 \mathrm{mg}, 7.4 \mu \mathrm{L}, 52.9 \mu \mathrm{mol}$. Purification of the product by preparative HPLC (flow rate: $15 \mathrm{~mL} / \mathrm{min}$; gradient: 0-30 min: 
$0.1 \%$ aq TFA/acetonitrile $\left.85: 15-38: 62, t_{\mathrm{R}}=12 \mathrm{~min}\right)$ afforded 16 as a red solid $(1.31 \mathrm{mg}, 34 \%)$. RP-HPLC $(220 \mathrm{~nm}): 98 \%\left(t_{\mathrm{R}}=16.6 \mathrm{~min}, k=4.8\right)$; HRMS $(\mathrm{ESI}): \mathrm{m} / z[\mathrm{M}]^{+}$calcd. for $\left[\mathrm{C}_{49} \mathrm{H}_{62} \mathrm{~N}_{7} \mathrm{O}_{2}\right]^{+}$780.4960, found: 780.4961. $\mathrm{C}_{49} \mathrm{H}_{62} \mathrm{~N}_{7} \mathrm{O}_{2}{ }^{+} \cdot \mathrm{C}_{8} \mathrm{H}_{3} \mathrm{~F}_{12} \mathrm{O}_{8}{ }^{-}(781.08+455.09)$.

\section{2-((1E,3E)-5-((E)-3,3-Dimethyl-1-(6-oxo-6-((2-(4-(4-(1-(2-oxo-2-(11-0xo-10,11-dihydro-}

\section{Hdibenzo[b,e][1,4]diazepin-5-yl)ethyl)piperidin-4-yl)butyl)piperazin-1-}

\section{yl)ethyl)amino)hexyl)indolin-2-ylidene)penta-1,3-dien-1-yl)-1,3,3-trimethyl-3H-indol-1-} ium tris(hydrotrifluoroacetate) trifluoroacetate (17). Compound 17 was prepared from amine $15(5.8 \mathrm{mg}, 5.95 \mu \mathrm{mol})$ and $11(3.0 \mathrm{mg}, 4.5 \mu \mathrm{mol})$ according to the procedure for the synthesis of 10, but DIPEA $(5.9 \mathrm{mg}, 7.9 \mu \mathrm{L}, 45 \mu \mathrm{mol})$ was used instead of triethylamine and the reaction time was $1 \mathrm{~h}$ instead of $2 \mathrm{~h}$. Purification by preparative HPLC (conditions as used for $\left.12, t_{\mathrm{R}}=19 \mathrm{~min}\right)$ afforded the product as a dark blue solid $(2.06 \mathrm{mg}, 31 \%)$. RP-HPLC (220 $\mathrm{nm}): 97 \%\left(t_{\mathrm{R}}=21.9 \mathrm{~min}, k=6.6\right) .{ }^{1} \mathrm{H}-\mathrm{NMR}\left(600 \mathrm{MHz}, \mathrm{MeOH}-d_{4}\right)$ (ratio of observed configurational isomers: ca 1.5:1): $\delta(\mathrm{ppm}) 1.31-1.41(\mathrm{~m}, 4 \mathrm{H}), 1.42-1.56(\mathrm{~m}, 5 \mathrm{H}), 1.64-1.75$ (m, 16H), 1.78-1.85 (m, 2H), 1.86-1.99 (m, 2H), $2.21(\mathrm{t}, J 7.5 \mathrm{~Hz}, 2 \mathrm{H})$, ca. 2.5-3.1 (brs, $4 \mathrm{H}$ (interfering with the next three listed signals)), 2.61-2.67 (m, 2H), 2.87-2.95 (m, 1H), 3.00-3.07 (m, 3H), ca. 3.1-3.5 (brs, 4H (interfering with the next two listed signals)), 3.31-3.34 (m, 2H (interfering with the solvent residual signal)), 3.41-3.48 (m, $1 \mathrm{H}$ (interfering with the ${ }^{13} \mathrm{C}$ satellite of the solvent residual signal)), $3.62(\mathrm{~s}, 3 \mathrm{H}), 3.68-3.81(\mathrm{~m}, 2 \mathrm{H}), 4.09(\mathrm{t}, J 7.4 \mathrm{~Hz}, 2 \mathrm{H}), 4.39$ (d, $J 17 \mathrm{~Hz}, 0.6 \mathrm{H}), 4.42(\mathrm{~d}, J 17 \mathrm{~Hz}, 0.4 \mathrm{H}), 6.26(\mathrm{~d}, J 14 \mathrm{~Hz}, 2 \mathrm{H}), 6.57-6.64(\mathrm{~m}, 1 \mathrm{H}), 7.23-7.35$ (m, 6H), 7.36-7.43 (m, 2.4H), 7.45-7.55 (m, 4.2H), 7.59-7.66 (m, 1.4H), 7.66-7.71 (m, 0.6H), 7.72-7.77 (m, 0.4H), 7.88-7.92 (m, 0.6H), 7.95-7.98 (m, 0.4H), 8.20-8.27 (m, 2H). HRMS (ESI): $m / z[\mathrm{M}]^{+}$calcd. for $\left[\mathrm{C}_{62} \mathrm{H}_{79} \mathrm{~N}_{8} \mathrm{O}_{3}\right]^{+}$983.6270, found: 983.6275. $\mathrm{C}_{62} \mathrm{H}_{79} \mathrm{~N}_{8} \mathrm{O}_{3}{ }^{+}$. $\mathrm{C}_{8} \mathrm{H}_{3} \mathrm{~F}_{12} \mathrm{O}_{8}{ }^{-}(984.37+455.09)$. 
4-(2-((1E,3E)-5-((E)-3,3-Dimethyl-1-(6-0xo-6-((2-(4-(4-(1-(2-0xo-2-(11-0xo-10,11dihydro-5H-dibenzo[b,e $][1,4]$ diazepin-5-yl)ethyl)piperidin-4-yl)butyl)piperazin-1yl)ethyl)amino)hexyl)indolin-2-ylidene)penta-1,3-dien-1-yl)-3,3-dimethyl-3H-indol-1ium-1-yl)butane-1-sulfonate tris(hydrotrifluoroacetate) (18). Compound 18 was prepared from amine 15 (3.7 mg, $3.8 \mu \mathrm{mol})$ and $\mathbf{1 3}(2.4 \mathrm{mg}, 3.4 \mu \mathrm{mol})$ according to the procedure for the synthesis of 10, but DIPEA $(4.4 \mathrm{mg}, 5.9 \mu \mathrm{L}, 34 \mu \mathrm{mol})$ was used instead of triethylamine and the reaction time was $1 \mathrm{~h}$ instead of $2 \mathrm{~h}$. Purification by preparative HPLC (conditions as used for $\left.12, t_{\mathrm{R}}=18 \mathrm{~min}\right)$ afforded the product as a dark blue solid $(1.59 \mathrm{mg}, 30 \%)$. RP-HPLC (220 $\mathrm{nm}): 96 \%\left(t_{\mathrm{R}}=21.3 \mathrm{~min}, k=6.4\right) .{ }^{1} \mathrm{H}-\mathrm{NMR}\left(600 \mathrm{MHz}, \mathrm{MeOH}-d_{4}\right)$ (ratio of observed configurational isomers: ca 1.5:1): $\delta(\mathrm{ppm}) 1.31-1.62(\mathrm{~m}, 9 \mathrm{H}), 1.65-1.77(\mathrm{~m}, 16 \mathrm{H}), 1.78-1.85$ (m, 2H), 1.86-2.01 (m, 6H), $2.23(\mathrm{t}, J 7.3 \mathrm{~Hz}, 2 \mathrm{H})$, ca. 2.4-3.6 (brs, 8H (interfering with the next five listed signals)), 2.70 (brs, 2H), 2.86-2.97 (m, 3H), 3.01-3.10 (m, 3H), 3.36 (brs, 2H), 3.40$3.46\left(\mathrm{~m}, 1 \mathrm{H}\right.$ (interfering with the ${ }^{13} \mathrm{C}$ satellite of the solvent residual signal)), 3.67-3.81 $(\mathrm{m}, 2 \mathrm{H})$, 4.09 (t, J 7.6 Hz, 2H), 4.13 (brs, 2H), 4.38 (d, J $17 \mathrm{~Hz}, 0.6 \mathrm{H}), 4.42$ (d, J 17 Hz, 0.4H), 6.27 (d, $J 14 \mathrm{~Hz}, 1 \mathrm{H}), 6.34$ (d, $J 14 \mathrm{~Hz}, 1 \mathrm{H}), 6.61-6.68(\mathrm{~m}, 1 \mathrm{H}), 7.23-7.30(\mathrm{~m}, 3.6 \mathrm{H}), 7.30-7.35$ (m, 2.4H), 7.35-7.42 (m, 2.4H), 7.45-7.55 (m, 4.2H), 7.59-7.70 (m, 2H), 7.72-7.76 (m, 0.4H), 7.88$7.91(\mathrm{~m}, 0.6 \mathrm{H})$, 7.95-7.98 (m, 0.4H), 8.20-8.27 (m, 2H). HRMS (ESI): $m / z[\mathrm{M}+\mathrm{H}]^{+}$calcd. for $\left[\mathrm{C}_{65} \mathrm{H}_{85} \mathrm{~N}_{8} \mathrm{O}_{6} \mathrm{~S}\right]^{+}$1105.6307, found: 1105.6309. $\mathrm{C}_{65} \mathrm{H}_{84} \mathrm{~N}_{8} \mathrm{O}_{6} \mathrm{~S} \cdot \mathrm{C}_{6} \mathrm{H}_{3} \mathrm{~F}_{9} \mathrm{O}_{6}(1105.50+342.07)$.

4-(2-((1E,3E)-5-((E)-3,3-dimethyl-1-(6-oxo-6-((2-(4-(4-(1-(2-oxo-2-(11-oxo-10,11-dihydro$5 H$-dibenzo[b,e][1,4]diazepin-5-yl)ethyl)piperidin-4-yl)butyl)piperazin-1-

yl)ethyl)amino)hexyl)-5-sulfoindolin-2-ylidene)penta-1,3-dien-1-yl)-3,3-dimethyl-3H-

indol-1-ium-1-yl)butane-1-sulfonate bis(hydrotrifluoroacetate) (20). Compound 20 was prepared from amine $\mathbf{1 5}(4.5 \mathrm{mg}, 4.6 \mu \mathrm{mol})$ and $\mathbf{1 9}(2.3 \mathrm{mg}, 2.9 \mu \mathrm{mol})$ according to the procedure for the synthesis of 10, but DIPEA $(4.2 \mathrm{mg}, 5.7 \mu \mathrm{L}, 33 \mu \mathrm{mol})$ was used instead of triethylamine and the reaction time was $1 \mathrm{~h}$ instead of $2 \mathrm{~h}$. Purification by preparative HPLC 
(conditions as used for $\mathbf{1 2}, t_{\mathrm{R}}=15 \mathrm{~min}$ ) afforded the product as a dark blue solid (1.45 $\mathrm{mg}$, 30\%). RP-HPLC (220 nm): 96\% $\left(t_{\mathrm{R}}=18.2 \mathrm{~min}, k=18.8\right) .{ }^{1} \mathrm{H}-\mathrm{NMR}\left(600 \mathrm{MHz}, \mathrm{MeOH}-d_{4}\right)$ (ratio of observed configurational isomers: ca 1.5:1): $\delta(\mathrm{ppm}) 1.34-1.56(\mathrm{~m}, 8 \mathrm{H}), 1.59-1.78(\mathrm{~m}$, 17H), 1.79-1.86 (m, 2H), 1.90-2.04 (m, 6H), 2.18 (t, J 6.8 Hz, 2H), 2.36 (brs, 2H), ca. 2.4 (brs, $1 \mathrm{H}), 2.80-3.14(\mathrm{~m}, 9 \mathrm{H})$, ca. 3.14-3.60 (brs, $4 \mathrm{H}$ (interfering with the next two listed signals)), 3.17-3.22 (m, $2 \mathrm{H}$ (interfering with ${ }^{13} \mathrm{C}$ satellite of the solvent residual signal)), 3.41-3.48 (m, $1 \mathrm{H}$ (interfering with the ${ }^{13} \mathrm{C}$ satellite of the solvent residual signal)), 3.70-3.83 (m, 2H), $4.07(\mathrm{t}$, $J 6.8 \mathrm{~Hz}, 2 \mathrm{H}), 4.22(\mathrm{t}, J 7.5 \mathrm{~Hz}, 2 \mathrm{H}), 4.38(\mathrm{~d}, J 17 \mathrm{~Hz}, 0.6 \mathrm{H}), 4.43(\mathrm{~d}, J 17 \mathrm{~Hz}, 0.4 \mathrm{H}), 6.21(\mathrm{~d}$, $J 13 \mathrm{~Hz}, 1 \mathrm{H}), 6.45(\mathrm{~d}, J 14 \mathrm{~Hz}, 1 \mathrm{H}), 6.64-6.71(\mathrm{~m}, 1 \mathrm{H}), 7.24-7.35(\mathrm{~m}, 4 \mathrm{H}), 7.36-7.40(\mathrm{~m}, 0.4 \mathrm{H})$, 7.40-7.48 (m, 2.6H), 7.48-7.55 (m, 2.6H), 7.59-7.70 (m, 2H), 7.72-7.76 (m, 0.4H), 7.81-7.86 (m, 2H), 7.88-7.91 (m, 0.6H), 7.95-7.98 (m, 0.4H), $8.21(\mathrm{t}, J 13 \mathrm{~Hz}, 1 \mathrm{H}), 8.29(\mathrm{t}, J 13 \mathrm{~Hz}, 1 \mathrm{H})$. HRMS (ESI): $m / z[\mathrm{M}+\mathrm{H}]^{+}$calcd. for $\left[\mathrm{C}_{65} \mathrm{H}_{85} \mathrm{~N}_{8} \mathrm{O}_{9} \mathrm{~S}_{2}\right]^{+}$1185.5875, found: 1185.5896 . $\mathrm{C}_{65} \mathrm{H}_{84} \mathrm{~N}_{8} \mathrm{O}_{9} \mathrm{~S}_{2} \cdot \mathrm{C}_{4} \mathrm{H}_{2} \mathrm{~F}_{6} \mathrm{O}_{4}(1185.55+228.05)$.

4-(2-((1E,3E)-5-((E)-3,3-dimethyl-1-(6-oxo-6-((2-)(3-(1-(4-(1-(2-0xo-2-(11-0xo-10,11dihydro-5H-dibenzo[b,e][1,4]diazepin-5-yl)ethyl)piperidin-4-yl)butyl)-1 $H$-imidazol-4yl)propanamido)ethyl)amino)hexyl)indolin-2-ylidene)penta-1,3-dien-1-yl)-3,3-dimethyl3H-indol-1-ium-1-yl)butane-1-sulfonate bis(hydrotrifluoroacetate) (22). The reaction was carried out in a $1.5-\mathrm{mL}$ polypropylene reaction vessel equipped with a micro stir bar. Amine 21 (7.0 mg, 7.6 $\mu \mathrm{mol})$ and DIPEA $(6.6 \mathrm{mg}, 9.0 \mu \mathrm{L}, 51 \mu \mathrm{mol})$ were dissolved in anhydrous DMF $(50 \mu \mathrm{L})$ followed by the addition of $\mathbf{1 3}(3.6 \mathrm{mg}, 5.1 \mu \mathrm{mol})$ in anhydrous DMF $(50 \mu \mathrm{L})$ and stirring was continued at $\mathrm{rt}$ in the dark for $1 \mathrm{~h} .10 \%$ aq TFA $(100 \mu \mathrm{L})$ was added and purification by preparative HPLC (flow rate: $18 \mathrm{~mL} / \mathrm{min}$; gradient: $0-25 \mathrm{~min}: 0.1 \%$ aq TFA/acetonitrile $\left.85: 15-55: 45, t_{\mathrm{R}}=18 \mathrm{~min}\right)$ afforded 22 as a dark blue fluffy solid $(2.4 \mathrm{mg}, 34 \%)$. RP-HPLC (220 $\mathrm{nm}): 99 \%\left(t_{\mathrm{R}}=14.5, k=14.8\right) .{ }^{1} \mathrm{H}-\mathrm{NMR}\left(600 \mathrm{MHz}, \mathrm{MeOH}-d_{4}\right)$ (ratio of observed configurational isomers: ca 1.5:1): $\delta$ (ppm) 1.32 (brs, $4 \mathrm{H}), 1.41-1.56(\mathrm{~m}, 5 \mathrm{H}), 1.64-1.76(\mathrm{~m}$, 
14H), 1.77-1.89 (m, 5H), 1.96 (brs, 5H), 2.20 (t, J 7.4 Hz, 2H), 2.57 (t, J 7.1 Hz, 2H), 2.87-2.98 $(\mathrm{m}, 5 \mathrm{H}), 3.01-3.07(\mathrm{~m}, 1 \mathrm{H}), 3.24(\mathrm{~s}, 4 \mathrm{H}), 3.41-3.47\left(\mathrm{~m}, 1 \mathrm{H}\right.$ (interfering with the ${ }^{13} \mathrm{C}$ satellite of the solvent residual signal)), 3.67-3.81 (m, 2H), $4.09(\mathrm{t}, J 7.4 \mathrm{~Hz}, 2 \mathrm{H}), 4.11-4.19(\mathrm{~m}, 4 \mathrm{H}), 4.38$ (d, $J 17 \mathrm{~Hz}, 0.6 \mathrm{H}), 4.43$ (d, $J 17 \mathrm{~Hz}, 0.4 \mathrm{H}), 6.23-6.28$ (m, 1H), 6.32-6.37 (m, 1H), 6.59-6.67 (m, 1H), 7.23-7.29 (m, 3.8H), 7.30-7.34 (m, 2.2H), 7.34-7.43 (m, 3.4H), 7.44-7.55 (m, 4.2H), 7.59-7.68 (m, 2H), 7.71-7.76 (m, 0.4H), 7.87-7.90 (m, 0.6H), 7.94-7.97 (m, 0.4H), 8.19-8.26 (m, 2H), 8.78 (brs, 1H). HRMS (ESI): $m / z[\mathrm{M}+2 \mathrm{H}]^{2+}$ calcd. for $\left[\mathrm{C}_{67} \mathrm{H}_{85} \mathrm{~N}_{9} \mathrm{O}_{7} \mathrm{~S}\right]^{2+}$ 579.8141, found: 579.8153. $\mathrm{C}_{67} \mathrm{H}_{83} \mathrm{~N}_{9} \mathrm{O}_{7} \mathrm{~S} \cdot \mathrm{C}_{4} \mathrm{H}_{2} \mathrm{~F}_{6} \mathrm{O}_{4}(1158.52+228.05)$.

4-(2-((1E,3E)-5-((E)-3,3-dimethyl-1-(6-oxo-6-((2-)(3-(1-(4-(1-(2-oxo-2-(11-0xo-10,11dihydro-5H-dibenzo[b,e][1,4]diazepin-5-yl)ethyl)piperidin-4-yl)butyl)-1H-imidazol-4yl)propanamido)ethyl)amino)hexyl)-5-sulfoindolin-2-ylidene)penta-1,3-dien-1-yl)-3,3dimethyl-3H-indol-1-ium-1-yl)butane-1-sulfonate hydrotrifluoroacetate (23). Compound $\mathbf{2 3}$ was prepared from amine $\mathbf{2 1}(3.2 \mathrm{mg}, 3.5 \mu \mathrm{mol})$ and $\mathbf{1 9}(1.9 \mathrm{mg}, 2.3 \mu \mathrm{mol})$ according to the procedure for the synthesis of 22. DIPEA: $3.0 \mathrm{mg}, 4.0 \mu \mathrm{L}, 23 \mu \mathrm{mol}$. Purification by preparative HPLC (conditions as used for $\mathbf{2 2}, t_{\mathrm{R}}=14 \mathrm{~min}$ ) afforded $\mathbf{2 3}$ as a dark blue fluffy solid (1.4 $\mathrm{mg}$, 41\%). RP-HPLC (220 nm): 98\% $\left(t_{\mathrm{R}}=10.0, k=9.9\right) .{ }^{1} \mathrm{H}-\mathrm{NMR}\left(600 \mathrm{MHz}, \mathrm{MeOH}-d_{4}\right)$ (ratio of observed configurational isomers: ca 1.5:1): $\delta$ (ppm) 1.31 (brs, $4 \mathrm{H}), 1.36-1.55(\mathrm{~m}, 5 \mathrm{H}), 1.62-$ $1.68(\mathrm{~m}, 2 \mathrm{H}), 1.69-1.72(\mathrm{~m}, 6 \mathrm{H}), 1.73(\mathrm{~s}, 6 \mathrm{H}), 1.77-1.86(\mathrm{~m}, 5 \mathrm{H}), 1.88-1.98(\mathrm{~m}, 3 \mathrm{H}), 2.01$ (brs, 2H), $2.16(\mathrm{t}, J 7.1 \mathrm{~Hz}, 2 \mathrm{H}), 2.55(\mathrm{t}, J 7.1 \mathrm{~Hz}, 2 \mathrm{H}), 2.88-2.97(\mathrm{~m}, 5 \mathrm{H}), 3.01-3.08(\mathrm{~m}, 1 \mathrm{H}), 3.15$ (s, 4H), 3.40-3.46 (m, $1 \mathrm{H}$ (interfering with the ${ }^{13} \mathrm{C}$ satellite of the solvent residual signal)), 3.69$3.81(\mathrm{~m}, 2 \mathrm{H}), 4.06(\mathrm{t}, J 6.7 \mathrm{~Hz}, 2 \mathrm{H}), 4.16(\mathrm{t}, J 7.2 \mathrm{~Hz}, 2 \mathrm{H}), 4.21(\mathrm{t}, J 7.0 \mathrm{~Hz}, 2 \mathrm{H}), 4.39(\mathrm{~d}, J 17$ Hz, 0.6H), 4.45 (d, J $17 \mathrm{~Hz}, 0.4 \mathrm{H}), 6.18-6.23(\mathrm{~m}, 1 \mathrm{H}), 6.49$ (d, J $14 \mathrm{~Hz}, 1 \mathrm{H}), 6.63-6.69(\mathrm{~m}, 1 \mathrm{H})$, 7.21-7.28 (m, 1.8H), 7.30-7.34 (m, 2.2H), 7.35-7.38 (m, 0.4H), 7.38-7.48 (m, 3.6H), 7.48-7.55 (m, 2.6H), 7.59-7.63 (m, 0.4H), 7.63-7.69 (m, 1.6H), 7.72-7.76 (m, 0.4H), 7.80-7.86 (m, 2H), 7.87-7.91 (m, 0.6H), 7.94-7.97 (m, 0.4H), $8.20(\mathrm{t}, J 13 \mathrm{~Hz}, 1 \mathrm{H}), 8.28$ (t, $J 13 \mathrm{~Hz}, 1 \mathrm{H}), 8.77$ (brs, 
1H). HRMS (ESI): $m / z[\mathrm{M}+2 \mathrm{H}]^{2+}$ calcd. for $\left[\mathrm{C}_{67} \mathrm{H}_{85} \mathrm{~N}_{9} \mathrm{O}_{10} \mathrm{~S}_{2}\right]^{2+}$ 619.7925, found: 619.7941 . $\mathrm{C}_{67} \mathrm{H}_{83} \mathrm{~N}_{9} \mathrm{O}_{10} \mathrm{~S}_{2} \cdot \mathrm{C}_{2} \mathrm{HF}_{3} \mathrm{O}_{2}(1238.58+114.02)$.

\section{4-(2-((1E,3E)-5-((E)-1-(6-)(3,5-bis((2-)(3-(1-(4-(1-(2-oxo-2-(11-oxo-10,11-dihydro-5H-} dibenzo[b,e][1,4]diazepin-5-yl)ethyl)piperidin-4-yl)butyl)-1 H-imidazol-4-

yl)propanamido)ethyl)carbamoyl)benzyl)amino)-6-oxohexyl)-3,3-dimethylindolin-2ylidene)penta-1,3-dien-1-yl)-3,3-dimethyl-3H-indol-1-ium-1-yl)butane-1-sulfonate tetrakis(hydrotrifluoroacetate) (27). Compound 27 was prepared from amine $\mathbf{2 6}(6.0 \mathrm{mg}, 4.6$ $\mu \mathrm{mol})$ and $\mathbf{1 3}(2.2 \mathrm{mg}, 3.1 \mu \mathrm{mol})$ according to the procedure for the synthesis of 22. DIPEA: $4.0 \mathrm{mg}, 5.4 \mu \mathrm{L}, 31 \mu \mathrm{mol}$. Purification by preparative HPLC (flow rate: $18 \mathrm{~mL} / \mathrm{min}$; gradient: 025 min: $0.1 \%$ aq TFA/acetonitrile $85: 15-40: 60, t_{\mathrm{R}}=16 \mathrm{~min}$ ) afforded 27 as a dark blue fluffy solid (2.6 mg, 36\%). RP-HPLC (220 nm): 99\% $\left(t_{\mathrm{R}}=13.3, k=13.5\right) .{ }^{1} \mathrm{H}-\mathrm{NMR}(600 \mathrm{MHz}$, $\left.\mathrm{MeOH}-d_{4}\right)$ (ratio of observed configurational isomers: ca 1.5:1): $\delta(\mathrm{ppm}) 1.30$ (brs, $\left.8 \mathrm{H}\right), 1.38-$ $1.56(\mathrm{~m}, 8 \mathrm{H}), 1.69(\mathrm{~s}, 6 \mathrm{H}), 1.71(\mathrm{~s}, 6 \mathrm{H}), 1.72-1.77(\mathrm{~m}, 2 \mathrm{H}), 1.78-1.88(\mathrm{~m}, 8 \mathrm{H}), 1.88-1.97$ (brs, 6H), $2.32(\mathrm{t}, J 7.1 \mathrm{~Hz}, 2 \mathrm{H}), 2.58(\mathrm{t}, J 7.1 \mathrm{~Hz}, 4 \mathrm{H}), 2.85-2.98(\mathrm{~m}, 8 \mathrm{H}), 3.03$ (brs, 2H), 3.37 (t, $J$ $6.0 \mathrm{~Hz}, 4 \mathrm{H}$ ), 3.43 (brs, $1 \mathrm{H}$ (interfering with the ${ }^{13} \mathrm{C}$ satellite of the solvent residual signal)), 3.44-3.49 (m, 5H), 3.66-3.82 (m, 4H), 4.06-4.16 (m, 8H), $4.39(\mathrm{~d}, J 17 \mathrm{~Hz}, 1.2 \mathrm{H}), 4.43(\mathrm{~d}, J 17$ Hz, 0.8H), 4.46 (s, 2H), 6.26 (d, J 14 Hz, 2H), 6.51 (t, J 12 Hz, 1H), 7.23-7.29 (m, 5H), 7.297.34 (m, 3H), 7.35 (brs, 2H), 7.36-7.42 (m, 2.6H), 7.44-7.52 (m, 6.6H), 7.59-7.68 (m, 4H), 7.71-7.75 (m, 0.8H), 7.87-7.90 (m, 1.2H), 7.91 (brs, 2H), 7.94-7.97 (m, 0.8H), 8.16-8.24 (m, $3 \mathrm{H}$ ), 8.75 (brs, $2 \mathrm{H})$. HRMS (ESI): $m / z[\mathrm{M}+4 \mathrm{H}]^{4+}$ calcd. for $\left[\mathrm{C}_{108} \mathrm{H}_{133} \mathrm{~N}_{17} \mathrm{O}_{12} \mathrm{~S}\right]^{4+}$ 473.0005, found: 473.0016. $\mathrm{C}_{108} \mathrm{H}_{129} \mathrm{~N}_{17} \mathrm{O}_{12} \mathrm{~S} \cdot \mathrm{C}_{8} \mathrm{H}_{4} \mathrm{~F}_{12} \mathrm{O}_{8}(1889.39+456.09)$.

\section{4-(2-((1E,3E)-5-((E)-1-(6-)(3,5-Bis((2-(3-(1-(4-(1-(2-oxo-2-(11-oxo-10,11-dihydro-5H- dibenzo[b,e][1,4]diazepin-5-yl)ethyl)piperidin-4-yl)butyl)-1 $H$-imidazol-4- yl)propanamido)ethyl)carbamoyl)benzyl)amino)-6-oxohexyl)-3,3-dimethyl-5-}


sulfoindolin-2-ylidene)penta-1,3-dien-1-yl)-3,3-dimethyl-3H-indol-1-ium-1-yl)butane-1sulfonate tris(hydrotrifluoroacetate) (28). Compound 28 was prepared from amine 26 (6.0 $\mathrm{mg}, 4.6 \mu \mathrm{mol})$ and $\mathbf{1 9}(7.6 \mathrm{mg}, 3.1 \mu \mathrm{mol})$ according to the procedure for the synthesis of $\mathbf{2 2}$. DIPEA: $4.0 \mathrm{mg}, 5.4 \mu \mathrm{L}, 31 \mu \mathrm{mol}$. Purification by preparative HPLC (conditions as used for 22, $\left.t_{\mathrm{R}}=15 \mathrm{~min}\right)$ afforded 28 as a dark blue fluffy solid (2.9 mg, 26\%). RP-HPLC (220 nm): 99\% $\left(t_{\mathrm{R}}=10.4, k=10.3\right) .{ }^{1} \mathrm{H}-\mathrm{NMR}\left(600 \mathrm{MHz}, \mathrm{MeOH}-d_{4}\right)$ (ratio of observed configurational isomers: ca 1.5:1): $\delta(\mathrm{ppm}) 1.30(\mathrm{brs}, 8 \mathrm{H}), 1.37-1.55(\mathrm{~m}, 8 \mathrm{H}), 1.65-1.74(\mathrm{~m}, 14 \mathrm{H}), 1.76-1.88(\mathrm{~m}, 8 \mathrm{H})$, 1.88-1.97 (m, 4H), 2.00 (brs, 2H), 2.28 (t, J 6.8 Hz, 2H), 2.58 (t, J 7.1 Hz, 4H), 2.86-2.97 (m, $8 \mathrm{H}), 3.04$ (brs, $2 \mathrm{H}), 3.35-3.39(\mathrm{~m}, 4 \mathrm{H}), 3.43$ (brs, $1 \mathrm{H}$ (interfering with the ${ }^{13} \mathrm{C}$ satellite of the solvent residual signal)), 3.44-3.48 (m, 5H), 3.67-3.82 (m, 4H), 4.04 (brs, 2H), 4.11 (t, J 7.2 Hz, 4H), $4.21(\mathrm{t}, J 7.1 \mathrm{~Hz}, 2 \mathrm{H}), 4.32$ (s, 2H), 4.39 (d, J $17 \mathrm{~Hz}, 1.2 \mathrm{H}), 4.44$ (d, J $17 \mathrm{~Hz}, 0.8 \mathrm{H})$, $6.17(\mathrm{~d}, J 13 \mathrm{~Hz}, 1 \mathrm{H}), 6.46(\mathrm{~d}, J 14 \mathrm{~Hz}, 1 \mathrm{H}), 6.55-6.63(\mathrm{~m}, 1 \mathrm{H}), 7.17(\mathrm{~d}, J 8.3 \mathrm{~Hz}, 1 \mathrm{H}), 7.23-$ $7.28(\mathrm{~m}, 1.6 \mathrm{H})$, 7.29-7.34 (m, 3.4H), 7.34-7.39 (m, 2.6H), 7.39-7.54 (m, 7.6H), 7.58-7.68 (m, 4H), 7.71-7.76 (m, 1.8H), 7.84 (brs, 1H), 7.87-7.91 (m, 3.2H), 7.93-7.97 (m, 0.8H), 8.12-8.20 (m, 2H), $8.26(\mathrm{t}, J 13 \mathrm{~Hz}, 1 \mathrm{H}), 8.74$ (brs, 2H). HRMS (ESI): $m / z[\mathrm{M}+3 \mathrm{H}]^{3+}$ calcd. for $\left[\mathrm{C}_{108} \mathrm{H}_{132} \mathrm{~N}_{17} \mathrm{O}_{15} \mathrm{~S}_{2}\right]^{3+}$ 656.9838, found: 656.9851. $\mathrm{C}_{108} \mathrm{H}_{129} \mathrm{~N}_{17} \mathrm{O}_{15} \mathrm{~S}_{2} \cdot \mathrm{C}_{6} \mathrm{H}_{3} \mathrm{~F}_{9} \mathrm{O}_{6}(1969.44+$ 342.07).

4-(2-((1E,3E)-5-((E)-3,3-dimethyl-1-(6-oxo-6-((3-((2-(4-(2-oxo-2,3-dihydro-1Hbenzo $[d]$ imidazol-1-yl)-[1,4'-bipiperidin]-1'-yl)ethyl)carbamoyl)-5-((2-(4-(4-(1-(2-oxo-2(11-0xo-10,11-dihydro-5H-dibenzo $[b, e][1,4]$ diazepin-5-yl)ethyl)piperidin-4yl)butyl)piperazin-1-yl)ethyl)carbamoyl)benzyl)amino)hexyl)-5-sulfoindolin-2ylidene)penta-1,3-dien-1-yl)-3,3-dimethyl-3H-indol-1-ium-1-yl)butane-1-sulfonate tetrakis(hydrotrifluoroacetate) (30). Compound $\mathbf{3 0}$ was prepared from amine 29 (5.0 $\mathrm{mg}, 4.9$ $\mu \mathrm{mol})$ and $\mathbf{1 9}(2.6 \mathrm{mg}, 3.3 \mu \mathrm{mol})$ according to the procedure used for the synthesis of 22 . DIPEA: $4.3 \mathrm{mg}, 6.0 \mu \mathrm{L}, 33 \mu \mathrm{mol}$. Purification by preparative HPLC (conditions as used for 22, 
$\left.t_{\mathrm{R}}=14 \mathrm{~min}\right)$ afforded 30 as a dark blue fluffy solid (2.3 mg, 34\%). RP-HPLC (220 nm): 97\% $\left(t_{\mathrm{R}}=9.4, k=9.2\right) .{ }^{1} \mathrm{H}-\mathrm{NMR}\left(600 \mathrm{MHz}, \mathrm{MeOH}-d_{4}\right)$ (ratio of observed configurational isomers: ca 1.5:1): $\delta(\mathrm{ppm}) 1.30-1.60(\mathrm{~m}, 9 \mathrm{H}), 1.64-1.77(\mathrm{~m}, 16 \mathrm{H}), 1.77-1.84(\mathrm{~m}, 2 \mathrm{H}), 1.86-1.98(\mathrm{~m}$, 4H), 1.98-2.05 (m, 2H), ca. 2.0-4.3 (brs, 8H (interfering with the next 16 listed signals)), 2.09$2.15(\mathrm{~m}, 2 \mathrm{H}), 2.24-2.35(\mathrm{~m}, 4 \mathrm{H}), 2.43-2.51(\mathrm{~m}, 2 \mathrm{H}), 2.67(\mathrm{t}, J 6.2 \mathrm{~Hz}, 2 \mathrm{H}), 2.82-2.91(\mathrm{~m}, 4 \mathrm{H})$, 2.91-2.98 (m, 1H), 3.01-3.09 (m, 3H), 3.13-3.23 (brs, $2 \mathrm{H}$ (interfering with the ${ }^{13} \mathrm{C}$ satellite of the solvent residual signal)), 3.32-3.38 (m, 2H), 3.39-3.47 (m, 3H), $3.50(\mathrm{t}, J 6.6 \mathrm{~Hz}, 2 \mathrm{H}), 3.66$ (brs, 1H), 3.69-3.83 (m, 6H), 3.98 (brs, 2H), $4.02(\mathrm{t}, J 7.1 \mathrm{~Hz}, 2 \mathrm{H}), 4.22(\mathrm{t}, J 7.3 \mathrm{~Hz}, 2 \mathrm{H}), 4.36$ (brs, 2H), 4.39 (d, J $17 \mathrm{~Hz}, 0.6 \mathrm{H}), 4.44(\mathrm{~d}, J 17 \mathrm{~Hz}, 0.4 \mathrm{H}), 4.59$ (tt, $J 12.3,4.3 \mathrm{~Hz}, 1 \mathrm{H}), 6.19$ (d, $J 13 \mathrm{~Hz}, 1 \mathrm{H}), 6.48(\mathrm{~d}, J 14 \mathrm{~Hz}, 1 \mathrm{H}), 6.63(\mathrm{t}, J 12 \mathrm{~Hz}, 1 \mathrm{H}), 7.02-7.09$ (m, 3H), $7.14(\mathrm{~d}, J 8.3 \mathrm{~Hz}$, 1H), 7.24-7.35 (m, 4H), 7.35-7.54 (m, 5.6H), 7.59-7.70 (m, 3H), 7.72-7.76 (m, 0.4H), 7.81 (brs, 1H), 7.88-7.91 (m, 0.6H), 7.93 (brs, 1H), 7.95-7.98 (m, 1.4H), 8.14 (t, J $13 \mathrm{~Hz}, 1 \mathrm{H}), 8.21$ (brs, $1 \mathrm{H}), 8.25(\mathrm{t}, J 13 \mathrm{~Hz}, 1 \mathrm{H})$. HRMS (ESI): $m / z[\mathrm{M}+3 \mathrm{H}]^{3+}$ calcd. for $\left[\mathrm{C}_{93} \mathrm{H}_{121} \mathrm{~N}_{14} \mathrm{O}_{12} \mathrm{~S}_{2}\right]^{3+}$ 563.2904, found: 563.2916. $\mathrm{C}_{93} \mathrm{H}_{118} \mathrm{~N}_{14} \mathrm{O}_{12} \mathrm{~S}_{2} \cdot \mathrm{C}_{8} \mathrm{H}_{4} \mathrm{~F}_{12} \mathrm{O}_{8}(1688.17+456.09)$.

Investigation of the chemical stability. The chemical stabilities of 20, 23, 28 and $\mathbf{3 0}$ were investigated in PBS pH 7.4 at $22 \pm 1{ }^{\circ} \mathrm{C}$ using siliconized (Sigmacote, Sigma) flat-bottom glass tubes ( $8.2 \times 40 \mathrm{~mm}$; Altmann Analytik, Munich, Germany) in case of 20 and 23, and different vessel materials (polypropylene, siliconized glass (the same type as for $\mathbf{2 0}$ and $\mathbf{2 3}$ ) or coated ("siliconized") polypropylene) for $\mathbf{2 8}$ and $\mathbf{3 0}$. The incubation was started by the addition of 10 $\mu \mathrm{L}$ of $1 \mathrm{mM}$ solution of the fluorescent ligand in DMSO to PBS $(90 \mu \mathrm{L})$ to yield a final concentration of $100 \mu \mathrm{M}$. After 0,24 and $48 \mathrm{~h}$, aliquots $(20 \mu \mathrm{L})$ were taken and added to $1 \%$ aq TFA/acetonitrile $(8: 2 \mathrm{v} / \mathrm{v})(20 \mu \mathrm{L})$. The resulting solutions were analyzed by RP-HPLC (analytical HPLC system and conditions see general experimental conditions; $t_{\mathrm{R}}: 18.2 \mathrm{~min}(\mathbf{2 0})$, $10.3 \min (\mathbf{2 3}), 10.4 \min (\mathbf{2 8}), 18.0 \min (\mathbf{3 0}))$. 
Determination of Fluorescence Quantum Yields. The determination of the fluorescence quantum yields of the fluorescently labeled ligands 16-18, 20, 22, 23 and 28, dissolved in PBS or PBS containing 1\% BSA, was performed with a Cary Eclipse spectrofluorimeter and a Cary 100 UV/VIS photometer (Varian Inc., Mulgrave, Victoria, Australia) as described previously with minor modifications. ${ }^{12}$ All spectra were recorded using acryl cuvettes $(10 \times 10 \mathrm{~mm}$, Ref. 67.755, Sarstedt, Nümbrecht, Germany). Fluorescence spectra were recorded at the slit adjustments (excitation/emission) 10/5 $\mathrm{nm}$ and 10/10 $\mathrm{nm}$ and resulting quantum yields were averaged. Table 7 provides an overview of the used concentrations of the fluorescent ligands and the applied excitation wavelengths. The concentration of cresyl violet perchlorate in EtOH was $2 \mu \mathrm{M}$. Fluorescence spectra of cresyl violet perchlorate were recorded using an excitation wavelength of $575 \mathrm{~nm}$.

Table 7. Fluorescent ligand concentrations and excitation wavelengths used for the determination of fluorescence quantum yields.

\begin{tabular}{ccccc}
\hline \multirow{2}{*}{ compd. } & \multicolumn{2}{c}{ concentration $[\mu \mathrm{M}]$} & \multicolumn{2}{c}{$\lambda_{\mathrm{ex}}[\mathrm{nm}]$} \\
\cline { 2 - 5 } & PBS & PBS + 1\% BSA & PBS & PBS + 1\% BSA \\
\hline $\mathbf{1 6}$ & 15 & 12 & 445 & 470 \\
$\mathbf{1 7}$ & 5 & 5 & 600 & 610 \\
$\mathbf{1 8}$ & 3 & 2 & 610 & 620 \\
$\mathbf{2 0}$ & 2 & 2 & 610 & 610 \\
$\mathbf{2 2}$ & 2.5 & 2.5 & 605 & 610 \\
$\mathbf{2 3}$ & 2.5 & 2.5 & 604 & 609 \\
$\mathbf{2 8}$ & 2.5 & 2.5 & 617 & 613 \\
\hline
\end{tabular}

Cell culture. CHO-K9 cells, stably transfected with the DNA of human muscarinic receptors $\mathrm{M}_{1}-\mathrm{M}_{5}$ (obtained from Missouri S\&T cDNA Resource Center; Rolla, MO) were cultured in HAM's F12 medium supplemented with fetal calf serum (Biochrom, Berlin, Germany) (10\%) and G418 (Biochrom) $(750 \mu \mathrm{g} / \mathrm{mL})$. 
IP1 accumulation assays. The $\mathrm{M}_{2} \mathrm{R}$ IP1 accumulation assay was performed as described elsewhere. ${ }^{38}$ In addition to the previously described conditions used for the investigation of $\mathrm{M}_{2} \mathrm{R}$ antagonism (preincubation of the cells with antagonist at $37^{\circ} \mathrm{C}$ for 30 min followed by addition of $\mathrm{CCh}(0.3 \mu \mathrm{M})$ and continuation of the incubation at $37^{\circ} \mathrm{C}$ for $\left.60 \mathrm{~min}\right)$, cells were preincubated with $\mathbf{2 0}$ or $\mathbf{2 3}$ at $22{ }^{\circ} \mathrm{C}$ for $180 \mathrm{~min}$ followed by addition of $\mathrm{CCh}$ (final concentration: $0.3 \mu \mathrm{M}$ ) and continuation of the incubation at $37^{\circ} \mathrm{C}$ for $90 \mathrm{~min}$.

The $\mathrm{M}_{4} \mathrm{R}$ IP1 accumulation assay was essentially performed as the previously described $\mathrm{M}_{2} \mathrm{R}$ IP1 accumulation assay ${ }^{38}$ using the cDNA of the human $\mathrm{M}_{4} \mathrm{R}$ (Missouri S\&T cDNA Resource Center) to prepare transiently transfected $\mathrm{HEK}-\mathrm{hM}_{4}-\mathrm{G} \alpha_{\mathrm{qi}}{ }^{-\mathrm{HA}}$ cells. To investigate $\mathrm{M}_{2} \mathrm{R}$ antagonism, cells were preincubated with the antagonist at $\mathrm{rt}$ for $180 \mathrm{~min}$ followed by addition of CCh (final concentration: $0.1 \mu \mathrm{M}$ ) and continuation of the incubation at $37^{\circ} \mathrm{C}$ for $90 \mathrm{~min}$.

Radioligand competition binding. Equilibrium competition binding experiments with $\left[{ }^{3} \mathrm{H}\right] \mathrm{NMS}$ were performed at intact $\mathrm{CHO}-\mathrm{hM}_{\mathrm{x}} \mathrm{R}$ cells $(\mathrm{x}=1-5)$ as described previously, ${ }^{42}$ but the total volume per well was $200 \mu \mathrm{L}$, i.e., in case of total binding, wells were filled with 180 $\mu \mathrm{L}$ of $\mathrm{L} 15$ medium followed by the addition of L15 medium $(20 \mu \mathrm{L})$ containing $\left[{ }^{3} \mathrm{H}\right] \mathrm{NMS}(10-$ fold concentrated). To determine unspecific binding and the effect of a compound of interest on $\left[{ }^{3} \mathrm{H}\right] \mathrm{NMS}$ equilibrium binding, wells were filled with $160 \mu \mathrm{L}$ of $\mathrm{L} 15$ medium followed by the addition of L15 medium $(20 \mu \mathrm{L})$ containing 31 or the compound of interest (10-fold concentrated) and L15 medium (20 $\mu \mathrm{L})$ containing $\left[{ }^{3} \mathrm{H}\right] \mathrm{NMS}$ (10-fold concentrated). Samples containing fluorescent ligand were incubated in the dark.

Flow cytometry. All flow cytometric binding studies (fluorescent ligands 18, 20, 23, 28 and 30) were performed with a FACSCalibur flow cytometer (Becton Dickinson, Heidelberg, Germany) (saturation and competition binding) or with a FACSCanto II (Becton Dickinson) 
(association and dissociation experiments), both equipped with an argon laser (488 $\mathrm{nm}$ ) and a red diode laser (635 and $640 \mathrm{~nm}$, respectively). Settings for forward and sideward scatter were: FSC: E-1, SSC: $280 \mathrm{~V}$ (FACSCalibur), or FSC: 0 V, SSC: 252 V (FACSCantoII). Fluorescence was recorded in channel FL-4 (excitation: $635 \mathrm{~nm}$, emission: $661 \pm 9 \mathrm{~nm}$, gain: 700-800 V) and in cannel APC-A (excitation: $640 \mathrm{~nm}$, emission: $660 \pm 10 \mathrm{~nm}$, gain: 510-540 V), respectively. Measurements were stopped after counting of 10,000 (FACSCanto II, flow rate: medium) or 20,000 (FACSCalibur, flow rate: high) gated events. Samples were prepared and incubated (22 ${ }^{\circ} \mathrm{C}$, in the dark) in $1.5 \mathrm{~mL}$ polypropylene reaction vessels (Sarstedt, Nümbrecht, Germany) or $50 \mathrm{~mL}$ polypropylene vessels (VWR International, Radnor, PA). All experiments were performed in duplicate. Cells were seeded in $175-\mathrm{cm}^{2}$ culture flasks 5-6 days prior to the experiment. On the day of the experiment, cells were treated with trypsin, suspended in culture medium and centrifuged. The cell pellet was re-suspended in Leibovitz's L15 culture medium (Gibco, Life Technologies, Darmstadt, Germany) supplemented with 1\% BSA (in the following referred to as L15 medium). The cell density was adjusted to $0.9-1.1 \times 10^{6}$ cells $/ \mathrm{mL}$. For saturation $(\mathbf{1 8}, \mathbf{2 0}, \mathbf{2 3}, \mathbf{2 8}, \mathbf{3 0})$ and competition (20) binding experiments, $1.5 \mathrm{~mL}$ reaction vessels were prefilled with $490 \mu \mathrm{L}$ of the cell suspension. For total binding, DMSO/ $\mathrm{H}_{2} \mathrm{O}(1: 1$ $\mathrm{v} / \mathrm{v})(5 \mu \mathrm{L})$ and $\mathrm{DMSO} / \mathrm{H}_{2} \mathrm{O}(1: 1 \mathrm{v} / \mathrm{v})(5 \mu \mathrm{L})$, containing the fluorescent ligand (100-fold concentrated), were added. To determine unspecific binding and in case of competition binding, DMSO $/ \mathrm{H}_{2} \mathrm{O}(1: 1 \mathrm{v} / \mathrm{v})(5 \mu \mathrm{L})$, containing atropine (31) (100-fold concentrated) and the compound of interest (100-fold concentrated), respectively, and DMSO/ $\mathrm{H}_{2} \mathrm{O}(1: 1 \mathrm{v} / \mathrm{v})(5 \mu \mathrm{L})$, containing the fluorescent ligand (100-fold concentrated), were added. For saturation binding experiments at the $\mathrm{M}_{2} \mathrm{R}$ the following final concentrations of fluorescent ligands were applied: 0.1-15 nM (18), 0.1-10 nM (20), 0.005-50 nM (23), 0.15-80 nM (28) and 0.04-20 nM (30). For saturation binding studies at the $\mathrm{M}_{1} \mathrm{R}$ and $\mathrm{M}_{4} \mathrm{R}$, compound $\mathbf{2 0}$ was applied at final concentrations of $0.15-80 \mathrm{nM}$. For competition binding experiments with 20, the final concentration of $\mathbf{2 0}$ was 1 or $20 \mathrm{nM}$. Unspecific binding was determined in the presence of $\mathbf{3 1}$ 
at 500-fold access to the fluorescent ligands. Samples were incubated at $22{ }^{\circ} \mathrm{C}$ in the dark under gentle shaking for $2 \mathrm{~h}$.

For association experiments with $20(1 \mathrm{nM}), \mathbf{2 3}(5 \mathrm{nM})$ and $28(3.5 \mathrm{nM})$ at $\mathrm{CHO}-\mathrm{hM}_{2} \mathrm{R}$ cells, $50 \mathrm{~mL}$ reaction vessels were prefilled with $5 \mathrm{~mL}$ (total binding) or $2.5 \mathrm{~mL}$ (unspecific binding) of the cell suspension. For total binding, DMSO/ $\mathrm{H}_{2} \mathrm{O}(2: 8 \mathrm{v} / \mathrm{v})(50 \mu \mathrm{L})$ and $\mathrm{DMSO} / \mathrm{H}_{2} \mathrm{O}(1: 1$ v/v) $(50 \mu \mathrm{L})$, containing $20(100 \mathrm{nM}), \mathbf{2 3}(500 \mathrm{nM})$ or $\mathbf{2 8}(350 \mathrm{nM})$, were added. To determine unspecific binding, DMSO/ $\mathrm{H}_{2} \mathrm{O}(2: 8 \mathrm{v} / \mathrm{v})(25 \mu \mathrm{L})$, containing $31(50,250$ and $175 \mu \mathrm{M}$, respectively), and $\mathrm{DMSO} / \mathrm{H}_{2} \mathrm{O}(1: 1 \mathrm{v} / \mathrm{v})(25 \mu \mathrm{L})$, containing $20(100 \mathrm{nM}), \mathbf{2 3}(500 \mathrm{nM})$ or 28 $(350 \mathrm{nM})$, were added to the cell suspension followed by incubation under gentle shaking in the dark. After different periods of time (1-300 min), aliquots $(200 \mu \mathrm{L})$ were taken and subjected to measurement. In the case of dissociation experiments, cells were preincubated with $20(3 \mathrm{nM}), \mathbf{2 3}(15 \mathrm{nM})$ or $\mathbf{2 8}(10 \mathrm{nM})$ for $180 \min (\mathbf{2 0}), 120 \min (\mathbf{2 3})$ or $110 \min (\mathbf{2 8})$. Vessels and sample volumes were the same as for association experiments. Unspecific binding was determined in the presence of $\mathbf{3 1}$ at final concentrations of $1.5,7.5$ and $5 \mu \mathrm{M}$, respectively. After preincubation with the fluorescent ligand under gentle shaking in the dark, the dissociation was started by the addition of $\mathbf{3 1}$ (100-fold concentrated in DMSO/water $(2: 8 \mathrm{v} / \mathrm{v}))$ to reach final concentrations of $\mathbf{3 1}$ of 3,15 and $10 \mu \mathrm{M}$, respectively. After different periods of time (2-540 min), aliquots $(200 \mu \mathrm{L})$ were taken and subjected to measurement. Dissociation experiments with 23 in the presence of the allosteric $M_{2} R$ ligands 32, 33 or 34, were performed as dissociation experiments in the absence of 32-34, but 1 min before the start of the dissociation by the addition of $\mathbf{3 1}$, compound $\mathbf{3 2 , 3 3}$ or $\mathbf{3 4}(10 \mu \mathrm{M}$ in DMSO) was added to reach a final concentration of $100 \mu \mathrm{M}$.

High-content imaging binding experiments. One day prior to the experiment, $\mathrm{CHO}-\mathrm{hM}_{2} \mathrm{R}$ or CHO-hM $\mathrm{R}_{1} \mathrm{R}$ cells were seeded at 35,000-40,000 cells per well into the central 60 wells of a black clear bottomed 96-well plate (Greiner 655090). On the day of the experiment the medium 
was removed by suction, the cells were washed with $\mathrm{HBSS}^{75}$ containing $0.1 \%$ BSA (in the following referred to as HBSS-BSA) $(50 \mu \mathrm{L})$, and covered with HBSS-BSA ( $80 \mu \mathrm{L})$ containing the permeable nuclear Hoechst dye H33342 $(2 \mu \mathrm{g} / \mathrm{mL}$ ). To determine total binding (saturation and competition binding experiments), HBSS-BSA $(10 \mu \mathrm{L})$ and HBSS-BSA $(10 \mu \mathrm{L})$ containing the fluorescent ligand (10-fold concentrated) were added. For the determination of unspecific binding and to study the effect of a compound of interest on $\mathrm{M}_{2} \mathrm{R}$ binding of the fluorescent ligand (competition binding assay), HBSS-BSA (10 $\mu \mathrm{L})$ containing 31 or the 'competitor' (10fold concentrated) and HBSS-BSA $(10 \mu \mathrm{L})$ containing the fluorescent ligand (10-fold concentrated) were added. Samples were incubated at rt in the dark for $60 \mathrm{~min}$. After incubation, images were directly acquired with the IX Ultra confocal plate reader (Molecular Devices, Sunnyvale CA) (to obtain "non-washing" saturation binding curves) or the cells were washed with HBSS-BSA $(50 \mu \mathrm{L})$ and covered with HBSS-BSA $(50 \mu \mathrm{L})$ followed by immediate acquisition of the images using the IX Ultra confocal plate reader. The washing procedure was performed within $<3 \mathrm{~min}$. The excitation laser lines of the Ultra plate reader were $405 \mathrm{~nm}$ (H33342) and $635 \mathrm{~nm}$ (Cy5). Two sites/well were measured throughout. The following final concentrations of 18, 20, 23 and $\mathbf{2 8}$ were applied for saturation binding studies: 0.1-70 nM (18 and 20, $\left.\mathrm{M}_{2} \mathrm{R}\right), 0.4-400 \mathrm{nM}\left(\mathbf{2 3}, \mathrm{M}_{1} \mathrm{R}\right), 0.4-200 \mathrm{nM}\left(\mathbf{2 3}, \mathrm{M}_{2} \mathrm{R}\right)$, and 0.2-100 $\mathrm{nM}\left(\mathbf{2 8}, \mathrm{M}_{1} \mathrm{R}\right.$ and $\mathrm{M}_{2} \mathrm{R}$ ). For competition binding experiments at $\mathrm{CHO}-\mathrm{hM}_{2} \mathrm{R}$ cells, 18, 20, 23 and 28 were applied at final concentrations of $10 \mathrm{nM}$. For the determination of unspecific binding, $\mathbf{3 1}$ was used at 500-fold (saturation binding) or 100-fold (competition binding) excess to the fluorescent ligand. Saturation binding experiments were performed in triplicate and competition binding assays were performed in duplicate. $\mathrm{M}_{2} \mathrm{R}$ saturation binding experiments with $\mathbf{2 0}, \mathbf{2 3}$ and $\mathbf{2 8}$ in the presence of 32 (Schild analysis) were performed as described above with the following modification: the cells were covered with $70 \mu \mathrm{L}$ of HBSS-BSA instead of $80 \mu \mathrm{L}$ to compensate the extra addition of HBSS-BSA $(10 \mu \mathrm{L})$ containing 32 (10-fold concentrated). The washing step prior to the measurement was performed. 
Confocal Microscopy. For the investigation of binding of 20, 23 and 28 to $\mathrm{CHO}-\mathrm{hM}_{2} \mathrm{R}$ cells by confocal microscopy, a previously described protocol for studying binding of fluorescently labeled neurotensin receptor ligands to $\mathrm{CHO}-\mathrm{hNTS}{ }_{1} \mathrm{R}$ cells, was used. ${ }^{27}$ The final fluorescent ligand concentration was $30 \mathrm{nM}$. Unspecific binding was determined in the presence of $\mathbf{3 1}$ (10 $\mu \mathrm{M})$. Images were acquired after an incubation period of 5-45 min with a Zeiss LSM 710 confocal laser scanning microscope (Zeiss, Jena, Germany). The objective was $63 \times$ magnification with oil (1.4 NA). The excitation laser lines were $405 \mathrm{~nm}$ and $633 \mathrm{~nm}$, filter settings were 410-514 nm (H33342 channel) and 638-759 nm (Cy5 channel), and the pinhole setting was 1.0 airy unit for the Cy5 channel.

Molecular dynamics simulation. For induced-fit docking, ligand $(\mathbf{2 3}, \mathbf{2 8})$ geometries were energetically optimized using the LigPrep module (Schrödinger LLC). Tertiary amine groups and imidazole moieties in $\mathbf{2 3}$ and $\mathbf{2 8}$ were protonated, and sulfonic acid groups were deprotonated resulting in net charges of +1 and +3 , respectively. Induced-fit docking (Schrödinger LLC) of $\mathbf{2 3}$ was performed using the output coordinates of the previously described docking of 6 at the $\mathrm{hM}_{2} \mathrm{R} .{ }^{38}$ For initial docking, Y104 ${ }^{3.33}$, Y403 ${ }^{6.51}$, and $\mathrm{Y} 426^{7.39}$ were mutated to alanine, and 23 was docked within a box of $46 \times 46 \times 46 \AA^{3}$ around the binding pose of 6. For redocking, the extended precision protocol was used. Induced-fit docking of $\mathbf{2 8}$ was performed using the output coordinates of the docking of 23. Initial docking was performed by analogy to that of $\mathbf{2 3}$, but core restraints were applied to the $N^{5}$-((piperidin-1yl)ethanoyl)dibenzodiazepinone partial structure with a maximum RMSD of $5 \AA$ based on the identical partial structure of 23. For redocking, the mutations of Y104 ${ }^{3.33}$, Y $403^{6.51}$, and $Y 426^{7.39}$ to alanine as well as the core restraints were maintained, and, after redocking, a second prime refinement stage was applied (including a reversion of the alanine mutations). The binding poses, corresponding to the lowest XP GScore, were selected as initial coordinates for MD 
simulations. The respective ligand-receptor complexes were aligned to the $\mathrm{hM}_{2} \mathrm{R}$ entry (PDB ID: $3 U \mathrm{UON})$ in the orientations of proteins in membranes (OPM) database ${ }^{76}$ using the protein structure alignment tool (Schrödinger LLC). The ligand-receptor complexes were inserted into a hydrated palmitoyloleoylphosphatidylcholine (POPC) bilayer (comprising 160 POPC molecules) as described for $\mathbf{6} .{ }^{38}$ The systems contained about 62,000 (23) and 65,000 (28) atoms and the initial box size was approximately $81 \times 81 \times 102 \AA^{3}$ and $81 \times 81 \times 106 \AA^{3}$, respectively. The parameters (geometry, partial charges) of the protein structure, compounds $\mathbf{2 3}$ and $\mathbf{2 8}$, lipids, inorganic ions, and water were assigned as reported. ${ }^{38} \mathrm{MD}$ simulations were executed on Nvidia GTX 1080Ti GPUs (approximately 11.5 TFlops) using the CUDA version of PMEMD, ${ }^{77,78}$ implemented in AMBER18 (AMBER 2018, University of California, San Francisco, CA). After minimization, the systems were heated from 0 to $100{ }^{\circ} \mathrm{K}$ in the NVT ensemble during $20 \mathrm{ps}$ and from 100 to $310^{\circ} \mathrm{K}$ in the NPT ensemble during $100 \mathrm{ps}$, applying harmonic restraints of $5 \mathrm{kcal} \mathrm{mol}^{-1} \AA^{-1}$ to non-hydrogen atoms of protein, lipids and ligand. The temperature and pressure coupling parameters used for the equilibration at $310^{\circ} \mathrm{K}$ (NPT ensemble) were the same as described for MD simulations of the $\mathrm{hM}_{2} \mathrm{R}$ bound to $6 .{ }^{38}$ During the $10 \mathrm{~ns}$ equilibration period, harmonic restraints on receptor non-hydrogen atoms were reduced stepwise $\left(0.5 \mathrm{kcal} \mathrm{mol}^{-1} \AA^{-1}\right.$ every $\left.0.5 \mathrm{~ns}\right)$ to $0.5 \mathrm{kcal} \mathrm{mol}^{-1} \AA^{-1}$ within $5 \mathrm{~ns}$. Harmonic restraints on ligand non-hydrogen atoms were reduced stepwise $\left(0.5 \mathrm{kcal} \mathrm{mol}^{-1} \AA^{-1}\right.$ every 0.5 ns) to $2.5 \mathrm{kcal} \mathrm{mol}^{-1} \AA^{-1}$ within $3 \mathrm{~ns}$. After 5 and $3 \mathrm{~ns}$, respectively, harmonic restraints on receptor and ligand non-hydrogen atoms were removed, i.e. the residual equilibration period (5 ns) was run without restraints. The interaction cutoff was set to 9.0 A. Long-range electrostatics were computed using the particle mesh Ewald (PME) method. ${ }^{79}$ To enable a frame step size of $4 \mathrm{fs}$, bonds involving hydrogen atoms were constrained using SHAKE ${ }^{80}$ and hydrogen mass repartitioning $(\mathrm{HMR})^{81}$ was applied. The final frame of the equilibration period was used as input for the simulations over $5.25 \mu$ s. After the equilibration period of $10 \mathrm{~ns}$, the Berendsen Barostat was replaced by the Monte Carlo Barostat algorithm. ${ }^{82}$ Cluster and H-bond analyses 
were performed as described, ${ }^{38}$ but data were collected every 500 ps using every tenth frame (5 ns step size). The first 250 ns of the simulations were omitted. Figures showing molecular structures (Figure 9A-D) were generated with PyMOL Molecular Graphics system, version 1.8.2.1 (Schrödinger LLC).

Data processing. Retention (capacity) factors were calculated from retention times $\left(t_{\mathrm{R}}\right)$ according to $k=\left(t_{\mathrm{R}}-t_{0}\right) / t_{0}\left(t_{0}=\right.$ dead time $)$. Data from the IP1 accumulation assay were processed as described previously, but $\mathrm{pIC}_{50}$ values were not converted to $\mathrm{p} K_{\mathrm{b}}$ values. ${ }^{38} \mathrm{Raw}$ data from flow cytometric experiments were processed with the aid of the FlowJo software (FlowJo LLC, Ashland, OR) to obtain geometrical mean values of FL-4 (FACSCalibur), or using the FACSDiva Software (Becton Dickinson) to obtain arithmetic mean values of the APC-A channel (FACSCanto II). Fluorescence arbitrary values from high-content imaging fluorescence images were obtained using a previously described procedure. ${ }^{13,27}$ Specific binding data from saturation binding experiments (flow cytometry, high-content imaging), obtained by subtracting unspecific binding data from total binding data, were plotted against the fluorescent ligand concentration and analyzed by a two-parameter equation describing hyperbolic binding (one site-specific binding, GraphPad Prism 5, GraphPad Software, San Diego, CA) to obtain $K_{\mathrm{d}}$ and $B_{\max }$ values. Unspecific binding data were fitted by linear regression. Additionally, specific binding data were plotted against log(fluorescent ligand concentration) and analyzed by a four-parameter logistic fit (log(agonist) vs. response, applied constraints: bottom $=0 \%$, top $=B_{\max }$ of the aforementioned two-parameter hyperbolic fit; GraphPad Prism) to obtain $\mathrm{p} K_{\mathrm{d}}$ values. In case of saturation binding experiments in the presence of compound 32, specific binding data were analyzed by a two-parameter equation describing hyperbolic binding (one site-specific binding, GraphPad Prism) to obtain $K_{\mathrm{d}}$ and $B_{\max }$ values. Additionally, specific binding data were normalized to the $B_{\max }$ value, specific binding (\%) was plotted against $\log ($ concentration $\mathbf{2 0}, \mathbf{2 3}$ or $\mathbf{2 8}$ ) followed by analysis using a four-parameter 
logistic fit $(\log ($ agonist $)$ vs. response, applied constraints: bottom $=0 \%$, top $=100 \%$, slope $=1$; GraphPad Prism). Data for the 'Schild' plot were obtained from the rightward shift $\left(\Delta \mathrm{p} K_{\mathrm{d}}\right)$ of the saturation isotherm and transformation into $\log (\mathrm{r}-1)$ (where $\left.\mathrm{r}=10^{\Delta \mathrm{p} K \mathrm{~d}}\right) \cdot \log (\mathrm{r}-1)$ was plotted against $\log$ (concentration of 32) and the data were analyzed by linear regression to obtain the slope and the ' $\mathrm{pA}_{2}$ ' value (intercept with the $\mathrm{X}$ axis). Specific binding data from association experiments with $\mathbf{2 0 ,} \mathbf{2 3}$ and $\mathbf{2 8}$ (flow cytometry) were analyzed by a two-parameter equation describing an exponential rise to a maximum (one-phase association) (SigmaPlot 11.0, Systat Software, Chicago, IL) to obtain the observed association rate constant $k_{\mathrm{obs}}$ and the maximum of specifically bound fluorescent ligand $\left(B_{\mathrm{eq}}\right)$, which was used to calculate specifically bound fluorescent ligand $\left(\mathrm{B}_{\mathrm{t}}\right)$ in \%. Data from dissociation experiments (flow cytometry) (\% specifically bound fluorescent ligand $\left(\mathrm{B}_{\mathrm{t}}\right)$ plotted over time) were analyzed by a three-parameter equation (incomplete one phase decay, SigmaPlot 11.0). The association rate constants $\left(k_{\text {on }}\right)$ of $\mathbf{2 0}, \mathbf{2 3}$ and $\mathbf{2 8}$ were calculated from $k_{\mathrm{obs}}, k_{\mathrm{off}}$ and the concentration of the fluorescent ligand used for the determination of $k_{\text {obs }}$ ([fluorescent ligand]) according to the equation: $k_{\mathrm{on}}=\left(k_{\mathrm{obs}}-k_{\mathrm{off}}\right) /[$ fluorescent ligand]. The kinetically derived dissociation constants $K_{\mathrm{d}}($ kin $)$ of 20, 23 and 28 were calculated according to: $K_{\mathrm{d}}(\mathrm{kin})=k_{\mathrm{off}} / k_{\mathrm{on}}$. Total binding data from competition binding experiments (radiochemical assays, flow cytometry, high-content imaging) were plotted against $\log$ (concentration competitor) and analyzed by a four-parameter logistic equation ( $\log ($ inhibitor) vs response - variable slope, GraphPad Prism) followed by normalization $(100 \%=$ "top" of the four-parameter logistic fit, $0 \%=$ unspecifically bound radioligand or fluorescent ligand) and analysis of the normalized data by a four-parameter logistic equation to obtain $\mathrm{pIC}_{50}$ values. The latter were converted to $\mathrm{p} K_{\mathrm{i}}$ values according to the Cheng-Prusoff equation ${ }^{83}$ (logarithmic form). Statistical significance (curve slopes) was assessed by a one-sample, two-tailed t-test. Propagated errors were calculated according to the general equation (1) (maximum error propagation). 


$$
\Delta \mathrm{z}=\left|\frac{\partial \mathrm{f}}{\partial \mathrm{x}_{1}}\right| \Delta \mathrm{x}_{1}+\left|\frac{\partial \mathrm{f}}{\partial \mathrm{x}_{2}}\right| \Delta \mathrm{x}_{2}+\ldots
$$

$\mathrm{f}$ : function of $\mathrm{x}_{1}, \mathrm{x}_{2}$, etc. $\left(\mathrm{f}\left(\mathrm{x}_{1}, \mathrm{x}_{2}, \ldots\right)=\mathrm{z}\right) ; \Delta \mathrm{x}_{1}, \Delta \mathrm{x}_{2}$ : error (in this work represented by the SEM) of $\mathrm{x}_{1}$ and $\mathrm{x}_{2} ; \Delta \mathrm{z}$ : (propagated) error of $\mathrm{z}$

\title{
Corresponding Author Information
}

*E-mail addresses: max.keller@ur.de (M.K.), nicholas.holliday@nottingham.ac.uk

(N.D.H.) Tel.: (+49)941 9433329 (M.K.), (+44)115 8230084 (N.D.H.)

Fax: (+49)9419434820 (M.K.)

\section{Present/Current author addresses}

\$Moffitt Cancer Center, 12902 Magnolia Drive, Tampa, Florida 33612, United States

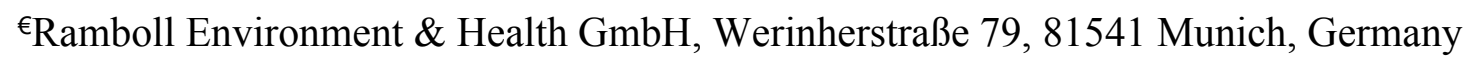

${ }^{¥}$ Leibniz Supercomputing Centre of the Bavarian Academy of Sciences and Humanities,

Boltzmannstraße 1, 85748 Garching, Germany

${ }^{\perp}$ Sanofi, R\&D China, 3/F, No. 108, Jian Guo Avenue, Chaoyang District, Beijing, 100022 , China

§Chengdu Kanghong Pharmaceutical Group Co. Ltd., No. 36, Shuxi Road, Jinniu District, Chengdu, 610036, China

\author{
Author Contributions \\ \#These authors contributed equally. X.S., A.P., M.K., M.C. and J.W. synthesized and \\ analytically characterized the florescent ligands. X.S., A.P., M.K. and C.G.G.
}


performed radiochemical and flow cytometric binding experiments and analyzed the data. X.S. and A.P. performed high-content imaging binding studies. H.H. and P.G. performed IP1 accumulation assays and analyzed the data. J.C. and N.D.H. performed confocal microscopy studies. D.W. performed MD simulations and processed the data. M.K. initiated and planned the project. M.K., N.D.H. and G.B. supervised the research. X.S., A.P., M.K., N.D.H., D.W. and G.B. wrote the manuscript. All authors have given approval to the final version of the manuscript.

\section{Notes \\ The authors declare no competing financial interest.}

\section{Acknowledgement}

The authors thank Brigitte Wenzl, Elvira Schreiber, Maria Beer-Krön, Dita Fritsch, and Susanne Bollwein for excellent technical assistance, Armin Buschauer for providing laboratory equipment and for helpful suggestions, as well as Seema Rajani and the School of Life Sciences imaging (SLIM) team (University of Nottingham) for their support in microscopy and analysis. Furthermore, the authors thank the Leibnitz Supercomputing Centre (LRZ) in Munich for providing software (Schrödinger Suite) and computing resources. This work was funded by the Graduate Training Program (Graduiertenkolleg) GRK1910 of the Deutsche Forschungsgemeinschaft (DFG) and by the China Scholarship Council (CSC).

\section{Abbreviations Used}


$\mathrm{B}_{0}$, specifically bound (fluorescent) ligand after the pre-incubation (before the start of the dissociation) of a dissociation experiment; $\mathrm{B}_{\mathrm{eq}}$, estimated maximum of specifically bound (fluorescent) ligand of an association experiment; $\mathrm{B}_{\mathrm{t}}$, specifically bound (fluorescent) ligand at time "t" of an association or a dissociation experiment; $\mathrm{CCh}$, carbachol; $\mathrm{MeCN}$, acetonitrile; CHO-cells, Chinese hamster ovary cells; DIPEA, diisopropylethylamine; GPCR, G-protein coupled receptor; HBSS, Hank's balanced salt solution; IP1, inositol monophosphate; $k$, retention (or capacity) factor (HPLC); $K_{\mathrm{d}}$, dissociation constant obtained from a saturation binding experiment; $k_{\mathrm{obs}}$, observed association rate constant; $k_{\mathrm{off}}$, dissociation rate constant; $k_{\mathrm{on}}$, association rate constant; MR, muscarinic receptor; NMS, N-methylscopolamine; PBS, phosphate buffered saline; $\mathrm{p} K_{\mathrm{b}}$, negative logarithm of the dissociation constant $K_{\mathrm{b}}$ (in $\mathrm{M}$ ) of an antagonist determined by inhibition of the response elicited by an agonist (functional assay); $\mathrm{p} K_{\mathrm{d}}$, negative logarithm of the $K_{\mathrm{d}}$ in $\mathrm{M} ; \mathrm{p} K_{\mathrm{i}}$, negative logarithm of the dissociation constant $K_{\mathrm{i}}$ (in $\mathrm{M}$ ) obtained from a competition binding experiment; RMSD, root mean square deviation; TFA, trifluoroacetic acid; $t_{\mathrm{R}}$, retention time.

\section{ASSOCIATED CONTENT}

Supporting Information Available: Figures S1-S11; Table S1; RP-HPLC chromatograms of compounds 10, 12, 14, 16-18, 20, 22, 23, 27, 28 and 30; ${ }^{1} \mathrm{H}-\mathrm{NMR}$ spectra of compounds 10 , $12,14,17,18,20,22,23,27,28$ and 30; molecular formula strings (CSV).

\section{References}

(1) Stoddart, L. A.; Kilpatrick, L. E.; Briddon, S. J.; Hill, S. J. Probing the pharmacology of G protein-coupled receptors with fluorescent ligands. Neuropharmacology 2015, 98, 4857. 
(2) Stoddart, L. A.; White, C. W.; Nguyen, K.; Hill, S. J.; Pfleger, K. D. G. Fluorescenceand bioluminescence-based approaches to study GPCR ligand binding. Br. J. Pharmacol. 2016, 173, 3028-3037.

(3) Stoddart, L. A.; Kilpatrick, L. E.; Hill, S. J. NanoBRET approaches to study ligand binding to GPCRs and RTKs. Trends Pharmacol. Sci. 2018, 39, 136-147.

(4) Rinken, A.; Veiksina, S.; Kopanchuk, S. Dynamics of ligand binding to GPCR: residence time of melanocortins and its modulation. Pharmacol. Res. 2016, 113, 747-753.

(5) Rinken, A.; Lavogina, D.; Kopanchuk, S. Assays with detection of fluorescence anisotropy: challenges and possibilities for characterizing ligand binding to GPCRs. Trends Pharmacol. Sci. 2018, 39, 187-199.

(6) Middleton, R. J.; Kellam, B. Fluorophore-tagged GPCR ligands. Curr. Opin. Chem. Biol. 2005, 9, 517-525.

(7) Kuder, K.; Kiec-Kononowicz, K. Fluorescent GPCR ligands as new tools in pharmacology. Curr. Med. Chem. 2008, 15, 2132-2143.

(8) Kuder, K. J.; Kiec-Kononowicz, K. Fluorescent GPCR ligands as new tools in pharmacology-update, years 2008- early 2014. Curr. Med. Chem. 2014, 21, 3962-3975.

(9) Dumont, Y.; Gaudreau, P.; Mazzuferi, M.; Langlois, D.; Chabot, J. G.; Fournier, A.; Simonato, M.; Quirion, R. BODIPY-conjugated neuropeptide Y ligands: new fluorescent tools to tag $\mathrm{Y}_{1}, \mathrm{Y}_{2}, \mathrm{Y}_{4}$ and $\mathrm{Y}_{5}$ receptor subtypes. Br. J. Pharmacol. 2005, 146, 1069-1081.

(10) Ziemek, R.; Brennauer, A.; Schneider, E.; Cabrele, C.; Beck-Sickinger, A. G.; Bernhardt, G.; Buschauer, A. Fluorescence- and luminescence-based methods for the determination of affinity and activity of neuropeptide $\mathrm{Y}_{2}$ receptor ligands. Eur. J. Pharmacol. 2006, 551, $10-18$.

(11) Schneider, E.; Keller, M.; Brennauer, A.; Hoefelschweiger, B. K.; Gross, D.; Wolfbeis, O. S.; Bernhardt, G.; Buschauer, A. Synthesis and characterization of the first fluorescent nonpeptide NPY $\mathrm{Y}_{1}$ receptor antagonist. ChemBioChem 2007, 8, 1981-1988. 
(12) Keller, M.; Erdmann, D.; Pop, N.; Pluym, N.; Teng, S.; Bernhardt, G.; Buschauer, A. Red-fluorescent argininamide-type NPY $\mathrm{Y}_{1}$ receptor antagonists as pharmacological tools. Bioorg. Med. Chem. 2011, 19, 2859-2878.

(13) Liu, M.; Richardson, R. R.; Mountford, S. J.; Zhang, L.; Tempone, M. H.; Herzog, H.; Holliday, N. D.; Thompson, P. E. Identification of a cyanine-dye labeled peptidic ligand for $\mathrm{Y}_{1} \mathrm{R}$ and $\mathrm{Y}_{4} \mathrm{R}$, based upon the neuropeptide $\mathrm{Y}$ C-terminal analogue, BVD-15. Bioconjug. Chem. 2016, 27, 2166-2175.

(14) Dukorn, S.; Littmann, T.; Keller, M.; Kuhn, K.; Cabrele, C.; Baumeister, P.; Bernhardt, G.; Buschauer, A. Fluorescence- and radiolabeling of $\left[\mathrm{Lys}^{4}, \mathrm{Nle}^{17,30}\right] \mathrm{hPP}$ yields molecular tools for the NPY $\mathrm{Y}_{4}$ receptor. Bioconjugate Chem. 2017, 28, 1291-1304.

(15) Li, L.; Kracht, J.; Peng, S.; Bernhardt, G.; Buschauer, A. Synthesis and pharmacological activity of fluorescent histamine $\mathrm{H}_{1}$ receptor antagonists related to mepyramine. Bioorg. Med. Chem. Lett. 2003, 13, 1245-1248.

(16) Li, L.; Kracht, J.; Peng, S.; Bernhardt, G.; Elz, S.; Buschauer, A. Synthesis and pharmacological activity of fluorescent histamine $\mathrm{H}_{2}$ receptor antagonists related to potentidine. Bioorg. Med. Chem. Lett. 2003, 13, 1717-1720.

(17) Malan, S. F.; van Marle, A.; Menge, W. M.; Zuliani, V.; Hoffman, M.; Timmerman, H.; Leurs, R. Fluorescent ligands for the histamine $\mathrm{H}_{2}$ receptor: synthesis and preliminary characterization. Bioorg. Med. Chem. 2004, 12, 6495-6503.

(18) Amon, M.; Ligneau, X.; Schwartz, J. C.; Stark, H. Fluorescent non-imidazole histamine $\mathrm{H}_{3}$ receptor ligands with nanomolar affinities. Bioorg. Med. Chem. Lett. 2006, 16, 19381940.

(19) Xie, S. X.; Petrache, G.; Schneider, E.; Ye, Q. Z.; Bernhardt, G.; Seifert, R.; Buschauer, A. Synthesis and pharmacological characterization of novel fluorescent histamine $\mathrm{H}_{2}$ receptor ligands derived from aminopotentidine. Bioorg. Med. Chem. Lett. 2006, 16, 3886-3890. 
(20) Arttamangkul, S.; Alvarez-Maubecin, V.; Thomas, G.; Williams, J. T.; Grandy, D. K. Binding and internalization of fluorescent opioid peptide conjugates in living cells. Mol. Pharmacol. 2000, 58, 1570-1580.

(21) Balboni, G.; Salvadori, S.; Dal Piaz, A.; Bortolotti, F.; Argazzi, R.; Negri, L.; Lattanzi, R.; Bryant, S. D.; Jinsmaa, Y.; Lazarus, L. H. Highly selective fluorescent analogue of the potent delta-opioid receptor antagonist Dmt-Tic. J. Med. Chem. 2004, 47, 6541-6546.

(22) Houghten, R. A.; Dooley, C. T.; Appel, J. R. De novo identification of highly active fluorescent kappa opioid ligands from a rhodamine labeled tetrapeptide positional scanning library. Bioorg. Med. Chem. Lett. 2004, 14, 1947-1951.

(23) Leopoldo, M.; Lacivita, E.; Passafiume, E.; Contino, M.; Colabufo, N. A.; Berardi, F.; Perrone, R. 4-[omega-[4-arylpiperazin-1-yl]alkoxy]phenyl)imidazo[1,2-a]pyridine derivatives: fluorescent high-affinity dopamine $\mathrm{D}_{3}$ receptor ligands as potential probes for receptor visualization. J. Med. Chem. 2007, 50, 5043-5047.

(24) Tabor, A.; Weisenburger, S.; Banerjee, A.; Purkayastha, N.; Kaindl, J. M.; Huebner, H.; Wei, L.; Groemer, T. W.; Kornhuber, J.; Tschammer, N.; Birdsall, N. J. M.; Mashanov, G. I.; Sandoghdar, V.; Gmeiner, P. Visualization and ligand-induced modulation of dopamine receptor dimerization at the single molecule level. Sci. Rep. 2016, 6, 33233.

(25) Keller, M.; Kuhn, K. K.; Einsiedel, J.; Hubner, H.; Biselli, S.; Mollereau, C.; Wifling, D.; Svobodova, J.; Bernhardt, G.; Cabrele, C.; Vanderheyden, P. M.; Gmeiner, P.; Buschauer, A. Mimicking of arginine by functionalized N(omega)-carbamoylated arginine as a new broadly applicable approach to labeled bioactive peptides: high affinity angiotensin, neuropeptide $\mathrm{Y}$, neuropeptide FF, and neurotensin receptor ligands as examples. $J$. Med. Chem. 2016, 59, 1925-1945.

(26) Faure, M. P.; Gaudreau, P.; Shaw, I.; Cashman, N. R.; Beaudet, A. Synthesis of a biologically active fluorescent probe for labeling neurotensin receptors. J. Histochem. Cytochem. 1994, 42, 755-763. 
(27) Keller, M.; Mahuroof, S. A.; Hong Yee, V.; Carpenter, J.; Schindler, L.; Littmann, T.; Pegoli, A.; Hubner, H.; Bernhardt, G.; Gmeiner, P.; Holliday, N. D. Fluorescence labeling of neurotensin(8-13) via arginine residues gives molecular tools with high receptor affinity. ACS Med. Chem. Lett. 2020, 11, 16-22.

(28) Spinnler, K.; von Kruchten, L.; Konieczny, A.; Schindler, L.; Bernhardt, G.; Keller, M. An alkyne-functionalized arginine for solid-phase synthesis enabling "bioorthogonal" peptide conjugation. ACS Med. Chem. Lett. 2020, 11, 334-339.

(29) Kozma, E.; Jayasekara, P. S.; Squarcialupi, L.; Paoletta, S.; Moro, S.; Federico, S.; Spalluto, G.; Jacobson, K. A. Fluorescent ligands for adenosine receptors. Bioorg. Med. Chem. Lett. 2013, 23, 26-36.

(30) Tahtaoui, C.; Parrot, I.; Klotz, P.; Guillier, F.; Galzi, J. L.; Hibert, M.; Ilien, B. Fluorescent pirenzepine derivatives as potential bitopic ligands of the human $M_{1}$ muscarinic receptor. J. Med. Chem. 2004, 47, 4300-4315.

(31) Daval, S. B.; Kellenberger, E.; Bonnet, D.; Utard, V.; Galzi, J.-L.; Ilien, B. Exploration of the orthosteric/allosteric interface in human $\mathrm{M}_{1}$ muscarinic receptors by bitopic fluorescent ligands. Mol. Pharmacol. 2013, 84, 71-85.

(32) Harris, A.; Cox, S.; Burns, D.; Norey, C. Miniaturization of fluorescence polarization receptor-binding assays using CyDye-labeled ligands. J. Biomol. Screening 2003, 8, 410420.

(33) Jones, L. H.; Randall, A.; Napier, C.; Trevethick, M.; Sreckovic, S.; Watson, J. Design and synthesis of a fluorescent muscarinic antagonist. Bioorg. Med. Chem. Lett. 2008, 18, $825-827$.

(34) Hern, J. A.; Baig, A. H.; Mashanov, G. I.; Birdsall, B.; Corrie, J. E. T.; Lazareno, S.; Molloy, J. E.; Birdsall, N. J. M. Formation and dissociation of $\mathrm{M}_{1}$ muscarinic receptor dimers seen by total internal reflection fluorescence imaging of single molecules. Proc. Natl. Acad. Sci. U. S. A. 2010, 107, 2693-2698. 
(35) Daval, S. B.; Valant, C.; Bonnet, D.; Kellenberger, E.; Hibert, M.; Galzi, J. L.; Ilien, B. Fluorescent derivatives of $\mathrm{AC}-42$ to probe bitopic orthosteric/allosteric binding mechanisms on muscarinic $\mathrm{M}_{1}$ receptors. J. Med. Chem. 2012, 55, 2125-2143.

(36) Nenasheva, T. A.; Neary, M.; Mashanov, G. I.; Birdsall, N. J.; Breckenridge, R. A.; Molloy, J. E. Abundance, distribution, mobility and oligomeric state of $\mathrm{M}(2)$ muscarinic acetylcholine receptors in live cardiac muscle. J. Mol. Cell. Cardiol. 2013, 57, 129-136.

(37) Mazzone, S. B.; Mori, N.; Burman, M.; Palovich, M.; Belmonte, K. E.; Canning, B. J. Fluorescent styryl dyes FM1-43 and FM2-10 are muscarinic receptor antagonists: intravital visualization of receptor occupancy. J. Physiol. 2006, 575, 23-35.

(38) Pegoli, A.; She, X.; Wifling, D.; Hübner, H.; Bernhardt, G.; Gmeiner, P.; Keller, M. Radiolabeled dibenzodiazepinone-type antagonists give evidence of dualsteric binding at the $\mathrm{M}_{2}$ muscarinic acetylcholine receptor. J. Med. Chem. 2017, 60, 3314-3334.

(39) She, X.; Pegoli, A.; Mayr, J.; Huebner, H.; Bernhardt, G.; Gmeiner, P.; Keller, M. Heterodimerization of dibenzodiazepinone-type muscarinic acetylcholine receptor ligands leads to increased $\mathrm{M}_{2} \mathrm{R}$ affinity and selectivity. ACS Omega 2017, 2, 6741-6754.

(40) Gitler, M. S.; Reba, R. C.; Cohen, V. I.; Rzeszotarski, W. J.; Baumgold, J. A novel m2selective muscarinic antagonist: binding characteristics and autoradiographic distribution in rat brain. Brain Res. 1992, 582, 253-260.

(41) She, X. Synthesis and pharmacological characterization of dibenzodiazepinone-type heterodimeric and fluorescently labeled muscarinic receptor ligands. Doctoral thesis. University of Regensburg, Regensburg, Germany, 2017, https://epub.uniregensburg.de/35508/.

(42) Keller, M.; Tränkle, C.; She, X.; Pegoli, A.; Bernhardt, G.; Buschauer, A.; Read, R. W. $\mathrm{M}_{2}$ Subtype preferring dibenzodiazepinone-type muscarinic receptor ligands: effect of chemical homo-dimerization on orthosteric (and allosteric?) binding. Bioorg. Med. Chem. 2015, 23, 3970-3990. 
(43) Wetzl, B. K.; Yarmoluk, S. M.; Craig, D. B.; Wolfbeis, O. S. Chameleon labels for staining and quantifying proteins. Angew. Chem., Int. Ed. 2004, 43, 5400-5402.

(44) Bridges, T. M.; Brady, A. E.; Kennedy, J. P.; Daniels, R. N.; Miller, N. R.; Kim, K.; Breininger, M. L.; Gentry, P. R.; Brogan, J. T.; Jones, C. K. Synthesis and SAR of analogues of the $\mathrm{M}_{1}$ allosteric agonist TBPB. Part I: exploration of alternative benzyl and privileged structure moieties. Bioorg. Med. Chem. Lett. 2008, 18, 5439-5442.

(45) Miller, N. R.; Daniels, R. N.; Bridges, T. M.; Brady, A. E.; Conn, P. J.; Lindsley, C. W. Synthesis and SAR of analogs of the $\mathrm{M}_{1}$ allosteric agonist TBPB. Part II: amides, sulfonamides and ureas - the effect of capping the distal basic piperidine nitrogen. Bioorg. Med. Chem. Lett. 2008, 18, 5443-5447.

(46) Jones, C. K.; Brady, A. E.; Davis, A. A.; Xiang, Z.; Bubser, M.; Tantawy, M. N.; Kane, A. S.; Bridges, T. M.; Kennedy, J. P.; Bradley, S. R. Novel selective allosteric activator of the $\mathrm{M}_{1}$ muscarinic acetylcholine receptor regulates amyloid processing and produces antipsychotic-like activity in rats. J. Neurosci. 2008, 28, 10422-10433.

(47) Keov, P.; Valant, C.; Devine, S. M.; Lane, J. R.; Scammells, P. J.; Sexton, P. M.; Christopoulos, A. Reverse engineering of the selective agonist TBPB unveils both orthosteric and allosteric modes of action at the $\mathrm{M}_{1}$ muscarinic acetylcholine receptor. Mol. Pharmacol. 2013, 84, 425-437.

(48) Prinz, H. Hill coefficients, dose-response curves and allosteric mechanisms. J. Chem. Biol. 2010, 3, 37-44.

(49) Smith, N. J.; Milligan, G. Allostery at G protein-coupled receptor homo- and heteromers: uncharted pharmacological landscapes. Pharmacol. Rev. 2010, 62, 701-725.

(50) Edelstein, S. J.; Le Novere, N. Cooperativity of allosteric receptors. J. Mol. Biol. 2013, 425, 1424-1432. 
(51) Bindslev, N. Drug-acceptor interactions: modeling theoretical tools to test and evaluate experimental equilibrium effects, open access e-book; 1st ed., Taylor \& Francis Group: 2017, https://doi.org/10.4324/9781315159782.

(52) Fish, I.; Stossel, A.; Eitel, K.; Valant, C.; Albold, S.; Huebner, H.; Moller, D.; Clark, M. J.; Sunahara, R. K.; Christopoulos, A.; Shoichet, B. K.; Gmeiner, P. Structure-based design and discovery of new $\mathrm{M}_{2}$ receptor agonists. J. Med. Chem. 2017, 60, 9239-9250.

(53) Copeland, R. A. Conformational adaptation in drug-target interactions and residence time. Future Med. Chem. 2011, 3, 1491-1501.

(54) Vauquelin, G. Simplified models for heterobivalent ligand binding: when are they applicable and which are the factors that affect their target residence time. Naunyn Schmiedebergs Arch. Pharmacol. 2013, 386, 949-962.

(55) Lüllmann, H.; Ohnesorge, F.; Schauwecker, G.-C.; Wassermann, O. Inhibition of the actions of carbachol and DFP on guinea pig isolated atria by alkane-bis-ammonium compounds. Eur. J. Pharmacol. 1969, 6, 241-247.

(56) Christopoulos, A.; Lanzafame, A.; Mitchelson, F. Allosteric interactions at muscarinic cholinoceptors. Clin. Exp. Pharmacol. Physiol. 1998, 25, 185-194.

(57) Holzgrabe, U.; Bender, W.; Botero Cid, H. M.; Staudt, M.; Pick, R.; Pfletschinger, C.; Balatkova, E.; Trankle, C.; Mohr, K. Ligands for the common allosteric site of acetylcholine $\mathrm{M}_{2}$-receptors: development and application. Pharm. Acta Helv. 2000, 74, $149-155$.

(58) Croy, C. H.; Schober, D. A.; Xiao, H.; Quets, A.; Christopoulos, A.; Felder, C. C. Characterization of the novel positive allosteric modulator, LY2119620, at the muscarinic $\mathrm{M}_{2}$ and $\mathrm{M}_{4}$ receptors. Mol. Pharmacol. 2014, 86, 106-115.

(59) Schober, D. A.; Croy, C. H.; Xiao, H.; Christopoulos, A.; Felder, C. C. Development of a radioligand, $\left[{ }^{3} \mathrm{H}\right] \mathrm{LY} 2119620$, to probe the human $\mathrm{M}_{2}$ and $\mathrm{M}_{4}$ muscarinic receptor allosteric binding sites. Mol. Pharmacol. 2014, 86, 116-123. 
(60) Jakubik, J.; Bacakova, L.; El-Fakahany, E. E.; Tucek, S. Positive cooperativity of acetylcholine and other agonists with allosteric ligands on muscarinic acetylcholine receptors. Mol. Pharmacol. 1997, 52, 172-179.

(61) Tränkle, C.; Weyand, O.; Voigtlander, U.; Mynett, A.; Lazareno, S.; Birdsall, N. J.; Mohr, K. Interactions of orthosteric and allosteric ligands with $\left[{ }^{3} \mathrm{H}\right]$ dimethyl-W84 at the common allosteric site of muscarinic $\mathrm{M}_{2}$ receptors. Mol. Pharmacol. 2003, 64, 180-190.

(62) Christopoulos, A.; Kenakin, T. G protein-coupled receptor allosterism and complexing. Pharmacol. Rev. 2002, 54, 323-374.

(63) Kenakin, T. A pharmacology primer: theory, application and methods; Academic Press: Burlington, MA, 2009.

(64) Hulme, E. C.; Trevethick, M. A. Ligand binding assays at equilibrium: validation and interpretation. Br. J. Pharmacol. 2010, 161, 1219-1237.

(65) Eberlein, W. G.; Engel, W.; Mihm, G.; Rudolf, K.; Wetzel, B.; Entzeroth, M.; Mayer, N.; Doods, H. N. Structure-activity relationships and pharmacological profile of selective tricyclic antimuscarinics. Trends Pharmacol. Sci. 1989, Suppl, 50-54.

(66) Tränkle, C.; Andresen, I.; Lambrecht, G.; Mohr, K. $\mathrm{M}_{2}$ receptor binding of the selective antagonist AF-DX 384: possible involvement of the common allosteric site. Mol. Pharmacol. 1998, 53, 304-312.

(67) Bermudez, M.; Rakers, C.; Wolber, G. Structural characteristics of the allosteric binding site represent a key to subtype selective modulators of muscarinic acetylcholine receptors. Mol. Inform. 2015, 34, 526-530.

(68) Suga, H.; Ehlert, F. J. Effects of asparagine mutagenesis of conserved aspartic acids in helix 2 (D2.50) and 3 (D3.32) of $\mathrm{M}_{1}-\mathrm{M}_{4}$ muscarinic receptors on the irreversible binding of nitrogen mustard analogs of acetylcholine and McN-A-343. Biochemistry 2013, 52, 4914-4928. 
(69) Thal, D. M.; Sun, B.; Feng, D.; Nawaratne, V.; Leach, K.; Felder, C. C.; Bures, M. G.; Evans, D. A.; Weis, W. I.; Bachhawat, P.; Kobilka, T. S.; Sexton, P. M.; Kobilka, B. K.; Christopoulos, A. Crystal structures of the $\mathrm{M}_{1}$ and $\mathrm{M}_{4}$ muscarinic acetylcholine receptors. Nature 2016, 531, 335-340.

(70) Haga, K.; Kruse, A. C.; Asada, H.; Yurugi-Kobayashi, T.; Shiroishi, M.; Zhang, C.; Weis, W. I.; Okada, T.; Kobilka, B. K.; Haga, T.; Kobayashi, T. Structure of the human $\mathrm{M}_{2}$ muscarinic acetylcholine receptor bound to an antagonist. Nature 2012, 482, 547-551.

(71) Pegoli, A.; Wifling, D.; Gruber, C. G.; She, X.; Hubner, H.; Bernhardt, G.; Gmeiner, P.; Keller, M. Conjugation of short peptides to dibenzodiazepinone-type muscarinic acetylcholine receptor ligands determines $\mathrm{M}_{2} \mathrm{R}$ selectivity. J. Med. Chem. 2019, 62, 53585369.

(72) Kane, B. E.; Grant, M. K.; El-Fakahany, E. E.; Ferguson, D. M. Synthesis and evaluation of xanomeline analogs - probing the wash-resistant phenomenon at the $M_{1}$ muscarinic acetylcholine receptor. Bioorg. Med. Chem. 2008, 16, 1376-1392.

(73) Hoefelschweiger, B. K. The pyrylium dyes: a new class of biolabels; synthesis, spectroscopy, and application as labels and in general protein assay. Doctoral Thesis. University of Regensburg, Regensburg, Germany, 2005, http://d-nb.info/975903071/34.

(74) Aldrich, C.; Bertozzi, C.; Georg, G. I.; Kiessling, L.; Lindsley, C.; Liotta, D.; Merz, K. M., Jr.; Schepartz, A.; Wang, S. The ecstasy and agony of assay interference compounds. J. Med. Chem. 2017, 60, 2165-2168.

(75) Watson, S.-J.; Brown, A. J. H.; Holliday, N. D. Differential signaling by splice variants of the human free fatty acid receptor GPR120. Mol. Pharmacol. 2012, 81, 631-642.

(76) Lomize, M. A.; Lomize, A. L.; Pogozheva, I. D.; Mosberg, H. I. OPM: orientations of proteins in membranes database. Bioinformatics 2006, 22, 623-625. 
(77) Salomon-Ferrer, R.; Gotz, A. W.; Poole, D.; Le Grand, S.; Walker, R. C. Routine microsecond molecular dynamics simulations with AMBER on GPUs. 2. explicit solvent particle mesh Ewald. J. Chem. Theory Comput. 2013, 9, 3878-3888.

(78) Le Grand, S.; Götz, A. W.; Walker, R. C. SPFP: Speed without compromise - a mixed precision model for GPU accelerated molecular dynamics simulations. Comput. Phys. Commun. 2013, 184, 374-380.

(79) Darden, T.; York, D.; Pedersen, L. Particle mesh Ewald: An N·log(N) method for Ewald sums in large systems. J. Chem. Phys. 1993, 98, 10089-10092.

(80) Ryckaert, J.-P.; Ciccotti, G.; Berendsen, H. J. C. Numerical integration of the cartesian equations of motion of a system with constraints: molecular dynamics of n-alkanes. $J$. Comput. Phys. 1977, 23, 327-341.

(81) Hopkins, C. W.; Le Grand, S.; Walker, R. C.; Roitberg, A. E. Long-time-step molecular dynamics through hydrogen mass repartitioning. J. Chem. Theory Comput. 2015, 11, 1864-1874.

(82) Chow, K.-H.; Ferguson, D. M. Isothermal-isobaric molecular dynamics simulations with Monte Carlo volume sampling. Comput. Phys. Commun. 1995, 91, 283-289.

(83) Cheng, Y.-C.; Prusoff, W. H. Relation between the inhibition constant $\mathrm{K}_{\mathrm{i}}$ and the concentration of inhibitor which causes fifty per cent inhibition $\left(\mathrm{IC}_{50}\right)$ of an enzymic reaction. Biochem. Pharmacol. 1973, 22, 3099-3108. 
TOC

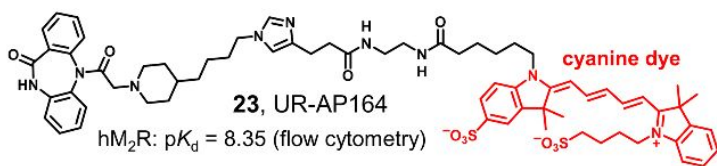

High-content imaging saturation binding ( $\mathrm{CHO}-\mathrm{hM}_{2} \mathrm{R}$ cells)

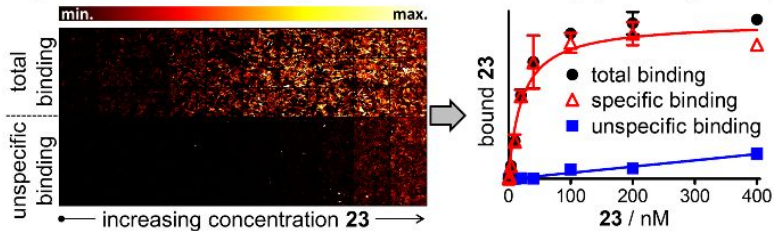




\section{Unable to Convert Image}

The dimensions of this image (in pixels) are too large to be converted. For this image to convert, the total number of pixels (height $x$ width) must be less than 40,000,000 (40 megapixels). 


\section{Unable to Convert Image}

The dimensions of this image (in pixels) are too large to be converted. For this image to convert, the total number of pixels (height $x$ width) must be less than 40,000,000 (40 megapixels). 

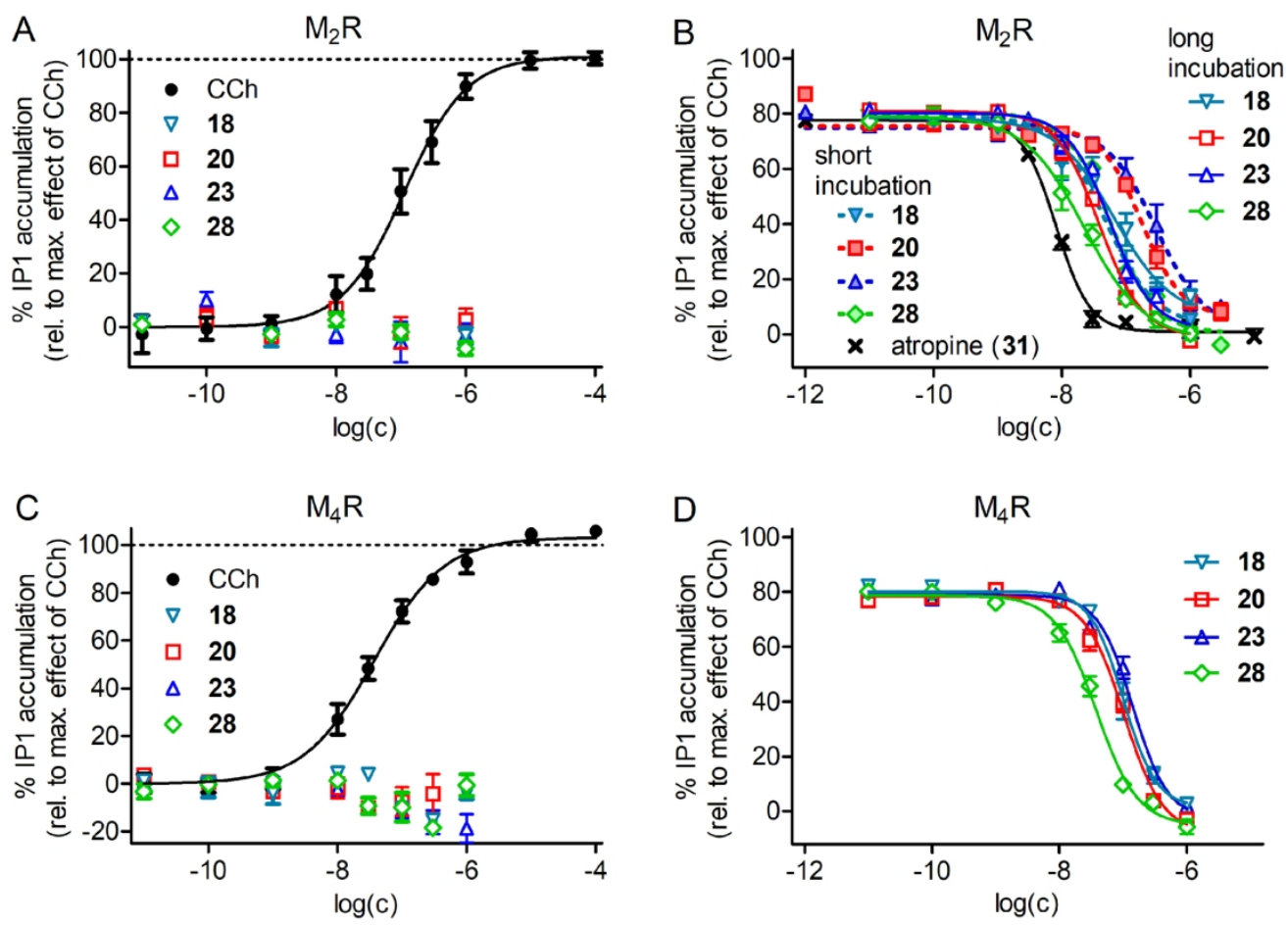

$177 \times 126 \mathrm{~mm}(300 \times 300 \mathrm{DPI})$ 

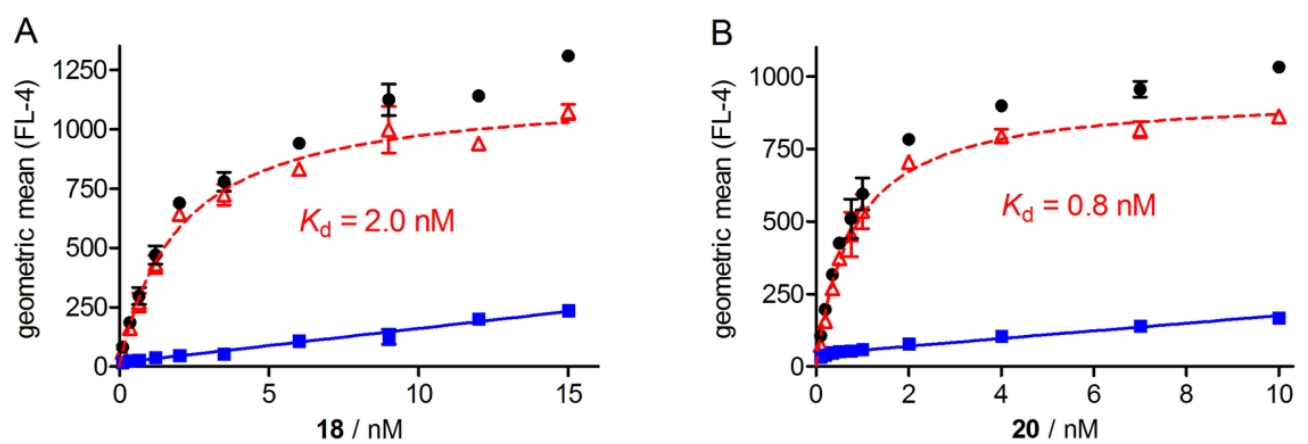

- total binding $\quad$ unspecific binding $\Delta$ specific binding
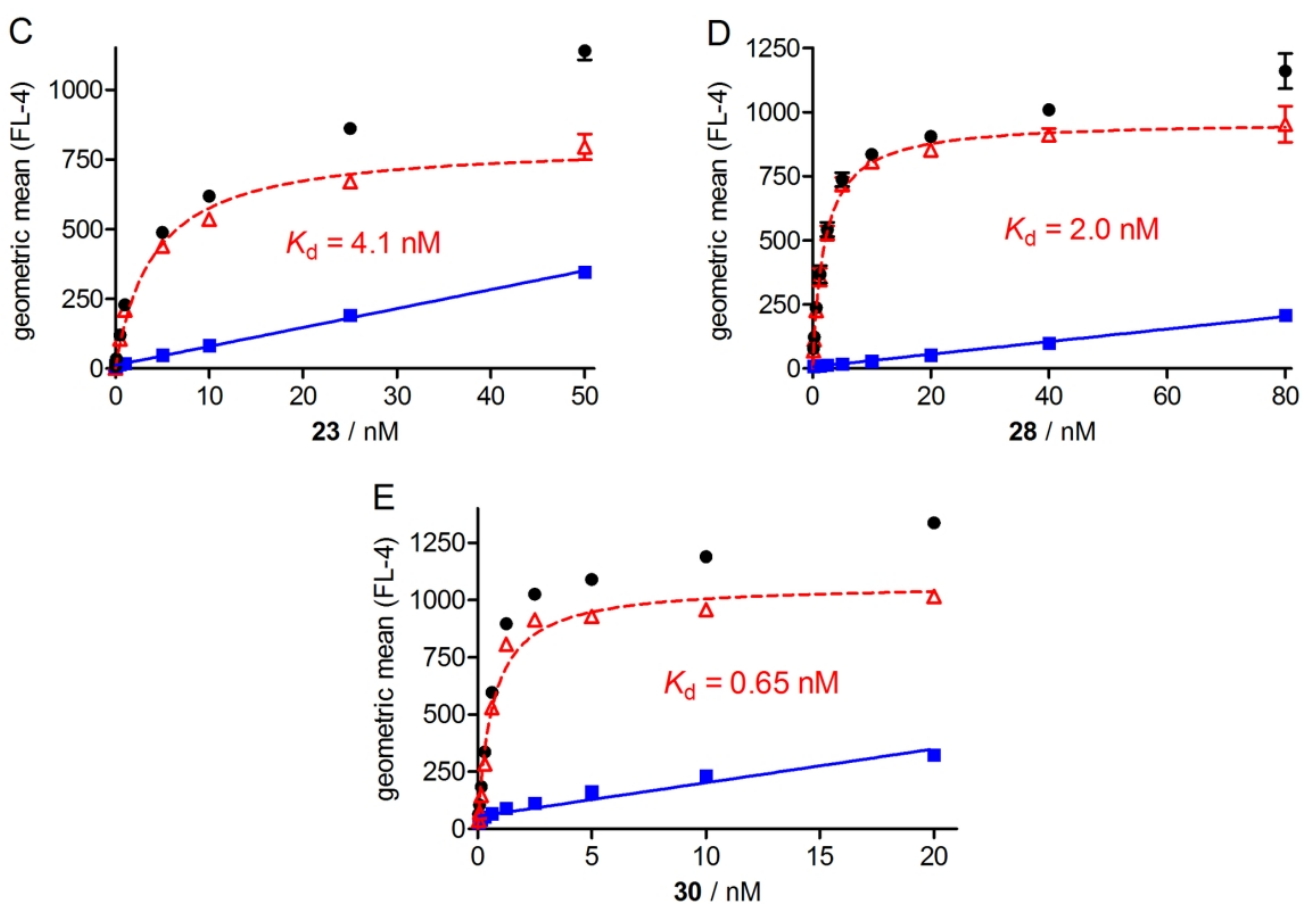

$175 \times 188 \mathrm{~mm}(300 \times 300$ DPI $)$ 

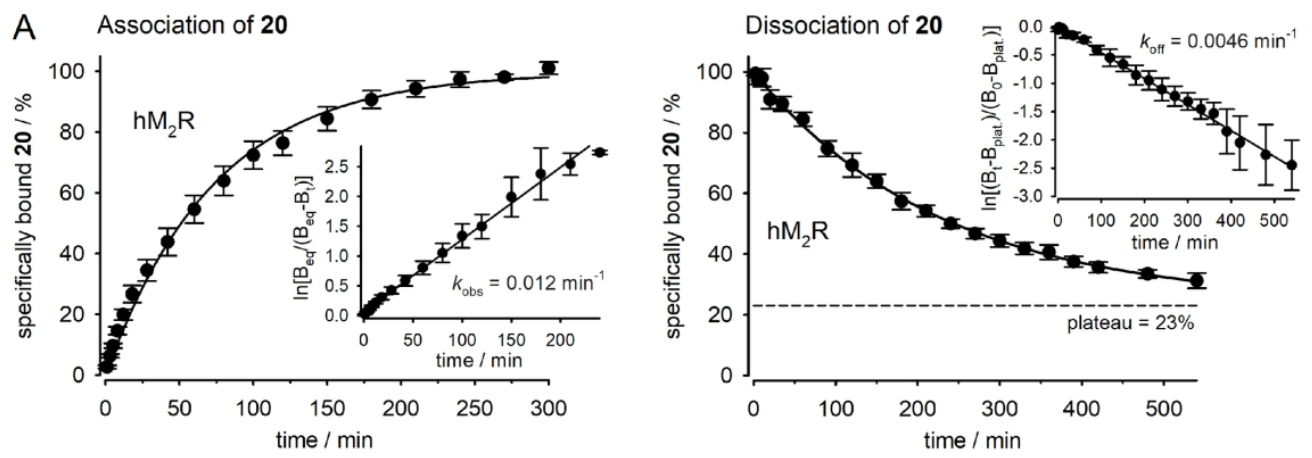

B Association of $\mathbf{2 3}$

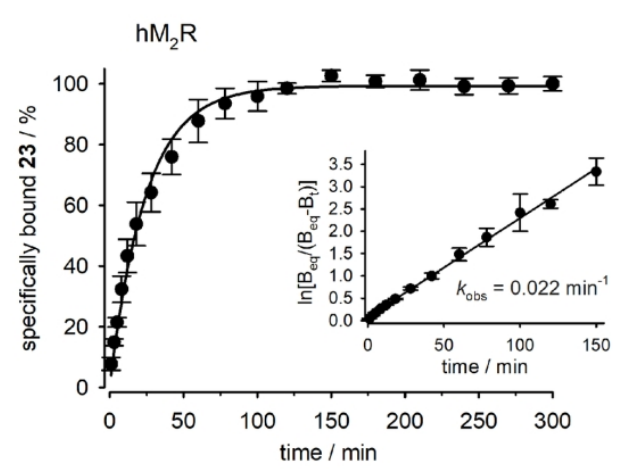

Dissociation of $\mathbf{2 3}$

determined in the presence of:

- $15 \mu \mathrm{M} 31$

ㅁ $15 \mu \mathrm{M} 31+100 \mu \mathrm{M} 32$ (W84)

$\Delta 15 \mu \mathrm{M} 31+100 \mu \mathrm{M} 33$ (LY2119620)

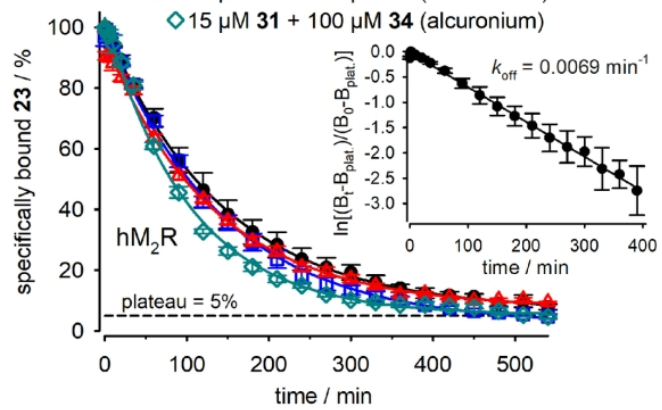

C Association of $\mathbf{2 8}$
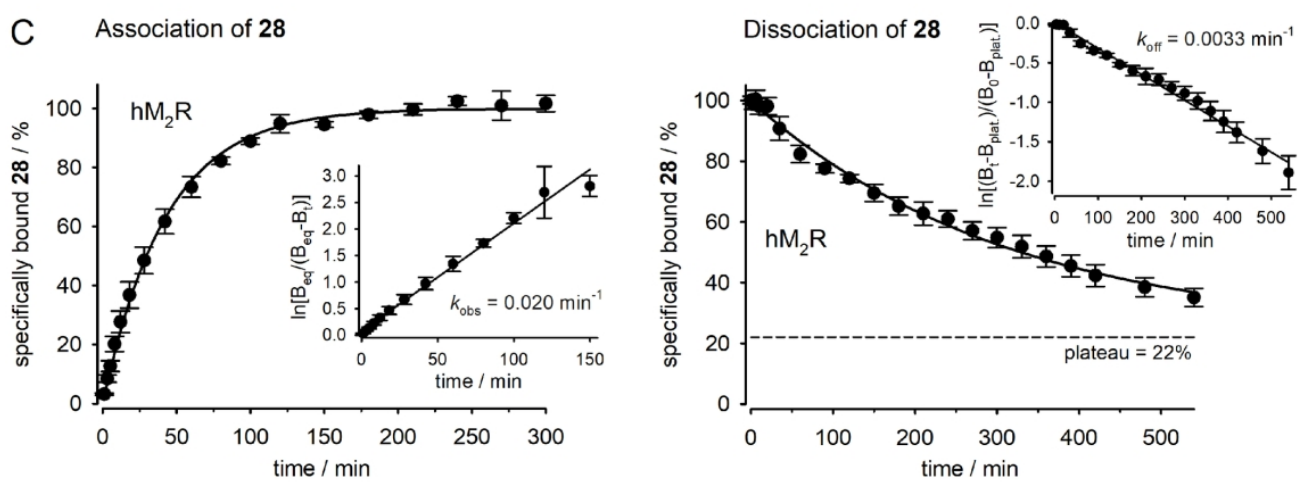

$177 \times 207 \mathrm{~mm}(300 \times 300$ DPI $)$ 


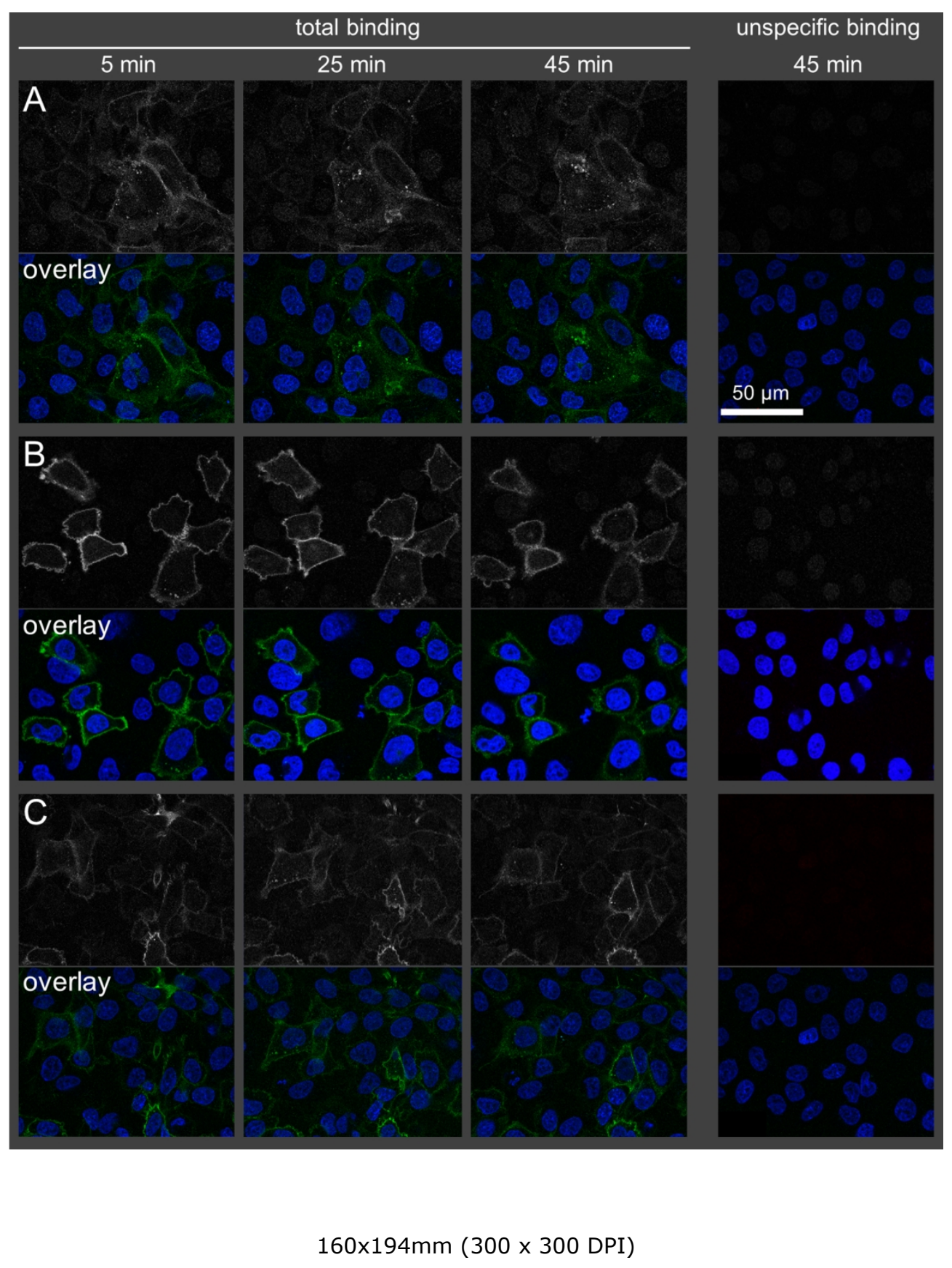

ACS Paragon Plus Environment 

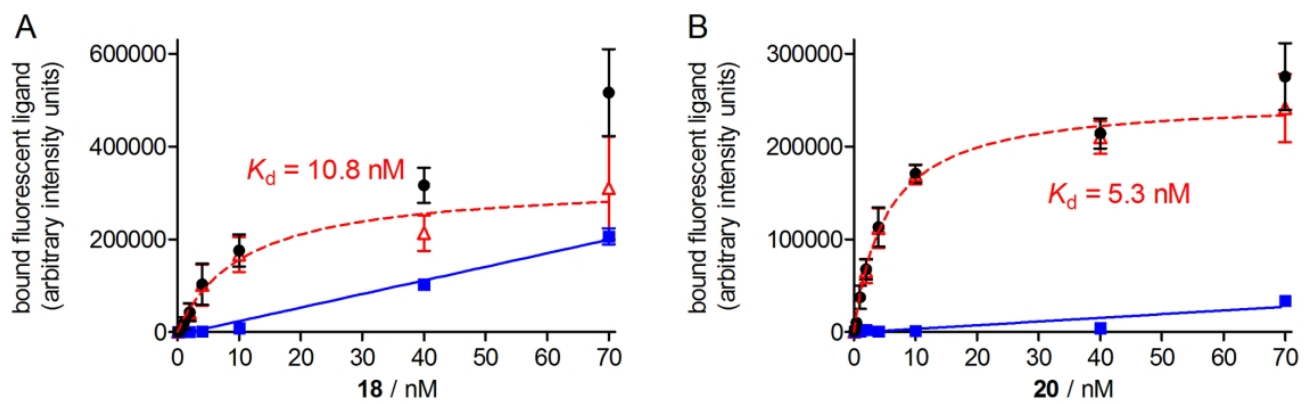

- total binding $\quad$ unspecific binding $\Delta$ specific binding
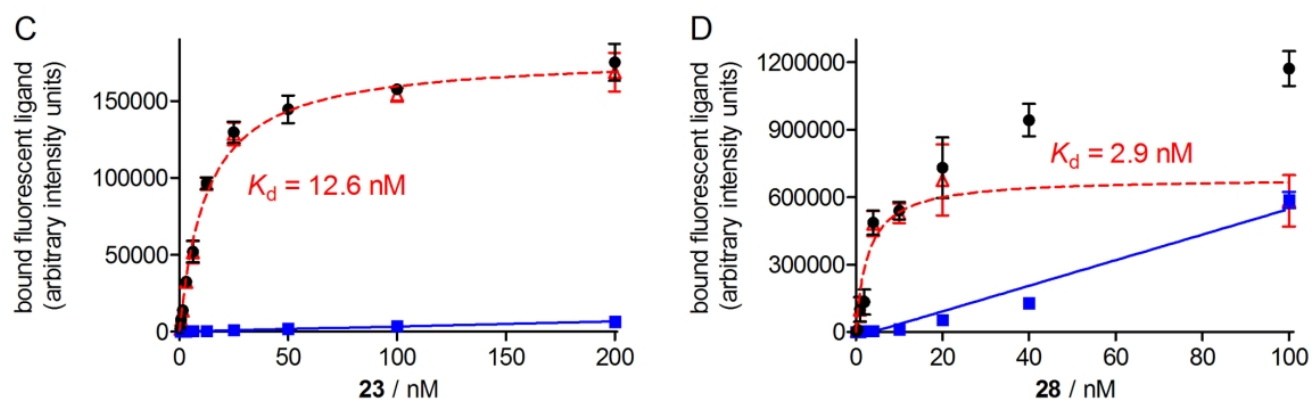

$177 \times 116 \mathrm{~mm}(300 \times 300 \mathrm{DPI})$ 

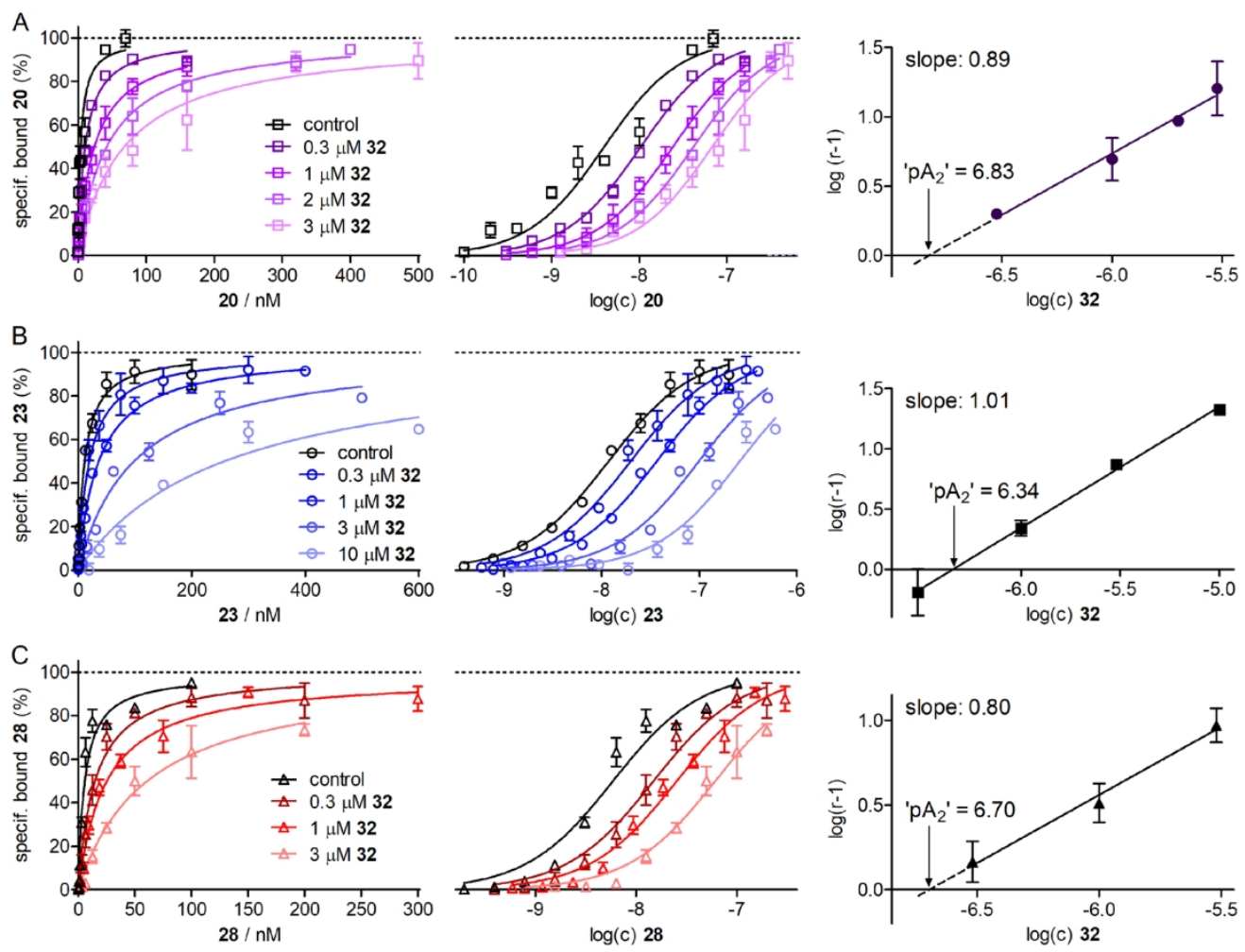

$177 \times 135 \mathrm{~mm}(300 \times 300 \mathrm{DPI})$ 

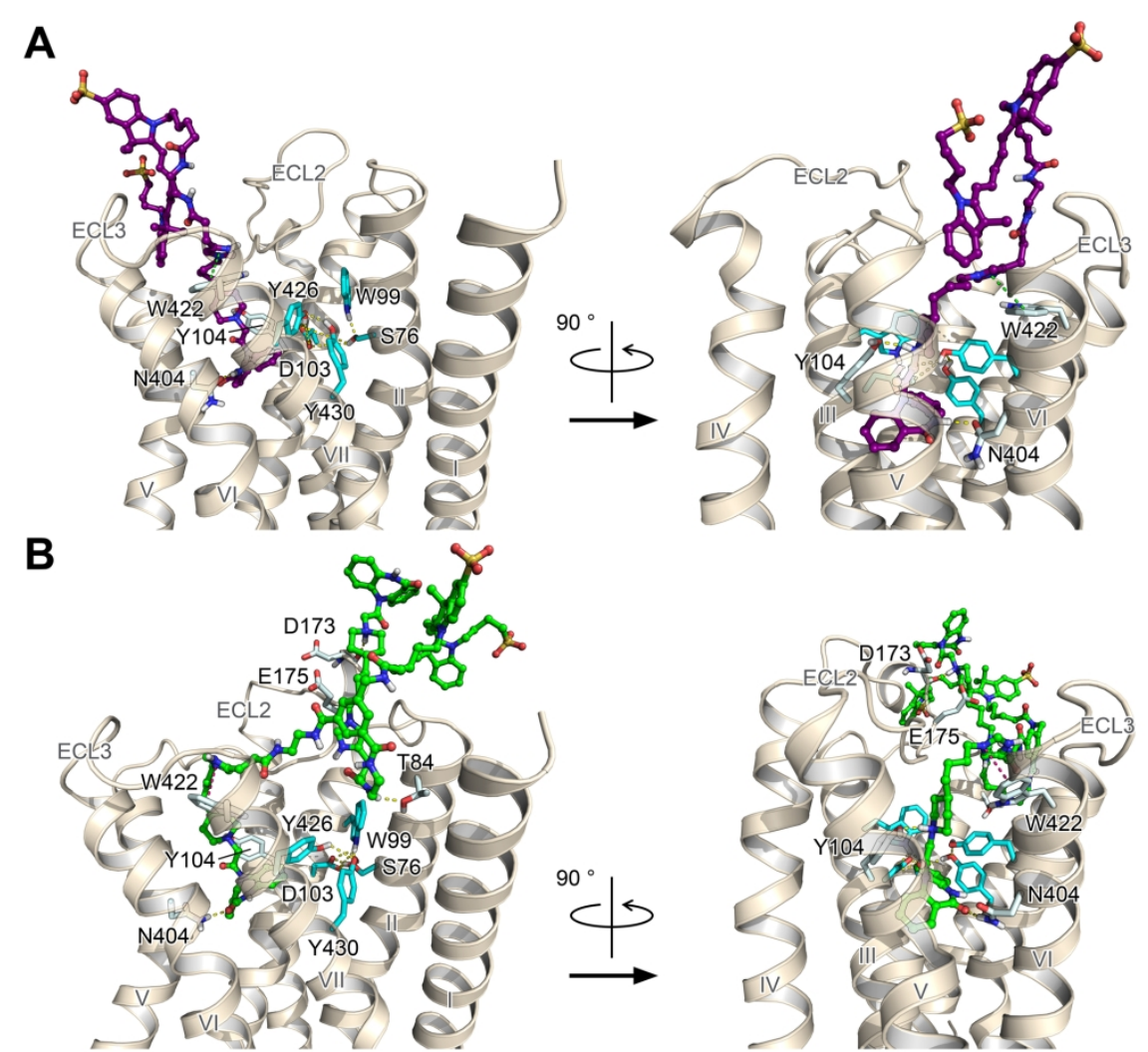

C
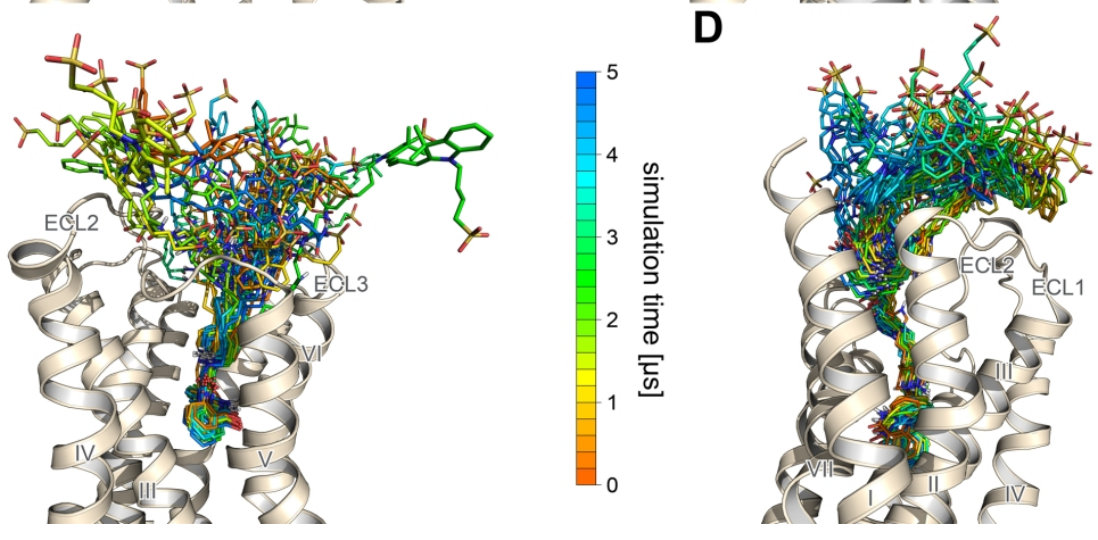

$167 \times 229 \mathrm{~mm}(300 \times 300$ DPI $)$ 


\section{Unable to Convert Image}

The dimensions of this image (in pixels) are too large to be converted. For this image to convert, the total number of pixels (height $x$ width) must be less than 40,000,000 (40 megapixels). 


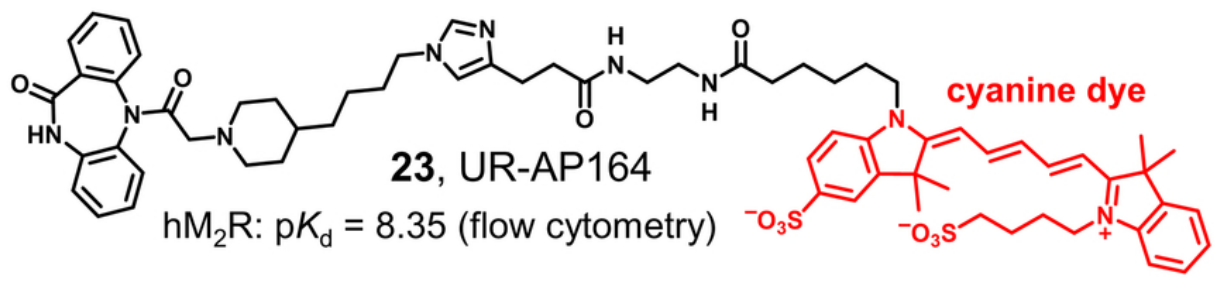

\section{High-content imaging saturation binding ( $\mathrm{CHO}-\mathrm{hM}_{2} \mathrm{R}$ cells)}
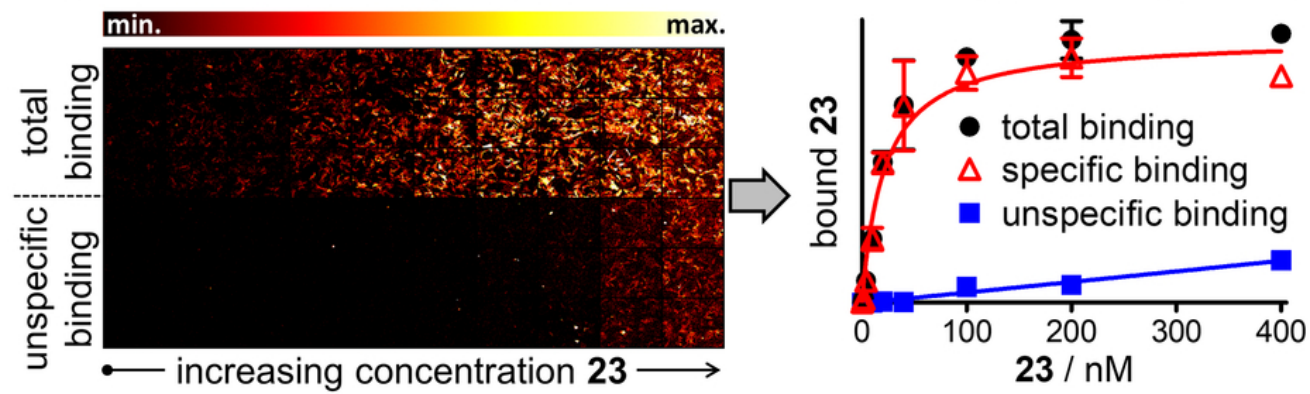

Note: for Table of Contents only

$78 \times 44 \mathrm{~mm}(300 \times 300$ DPI) 